Prepared in cooperation with the West Virginia Department of Health and Human Resources, Bureau of Public Health, Office of Environmental Health Services

\title{
Assessment of Hydrogeologic Terrains, Well-Construction Characteristics, Groundwater Hydraulics, and Water-Quality and Microbial Data for Determination of Surface-Water- Influenced Groundwater Supplies in West Virginia
}

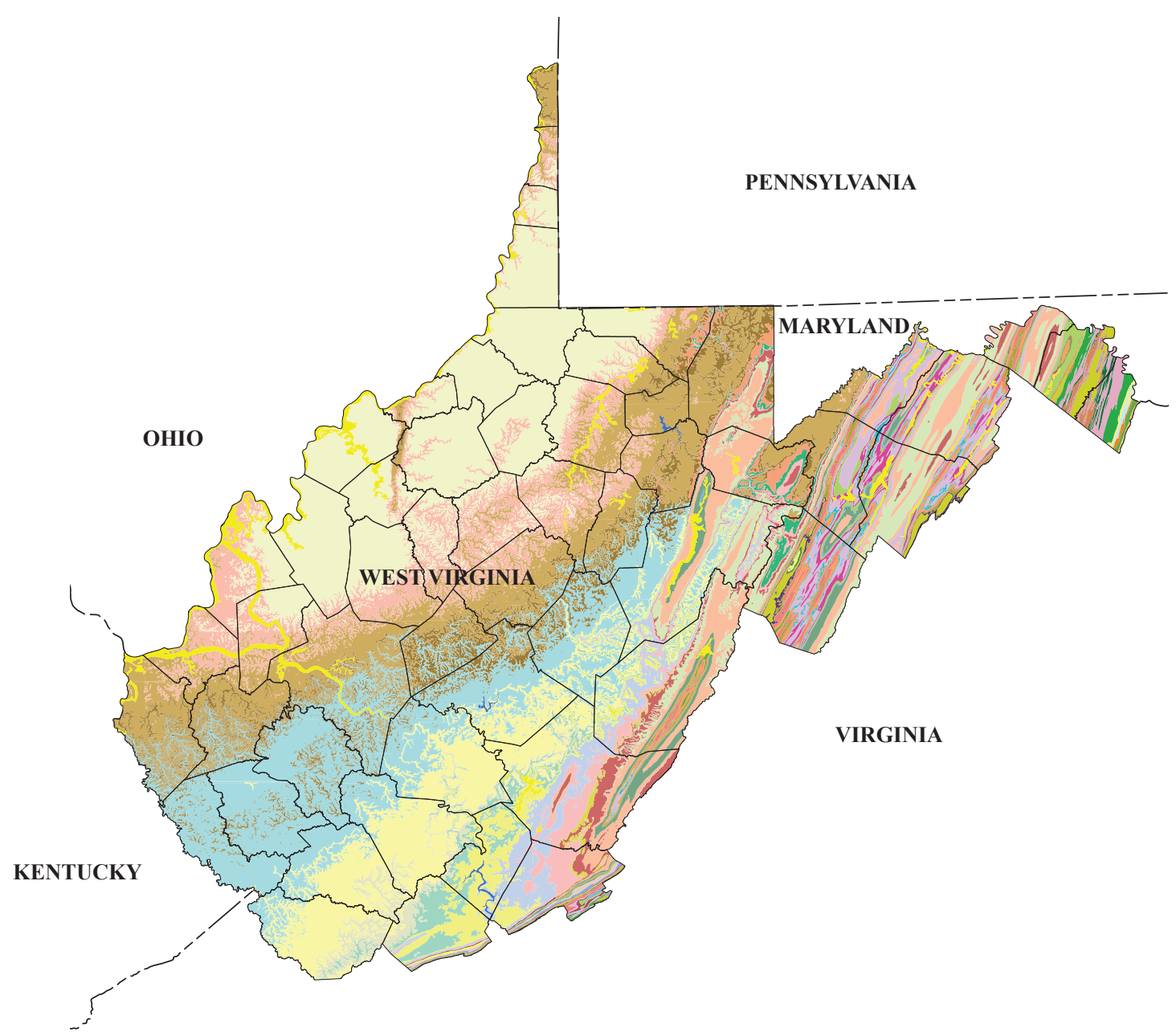

Scientific Investigations Report 2016-5048

Version 1.1, October 2016 



\section{Assessment of Hydrogeologic Terrains, Well-Construction Characteristics, Groundwater Hydraulics, and Water-Quality and Microbial Data for Determination of Surface-Water-Influenced Groundwater Supplies in West Virginia}

By Mark D. Kozar and Katherine S. Paybins

Prepared in cooperation with the

West Virginia Department of Health and Human Resources, Bureau

of Public Health, Office of Environmental Health Services

Scientific Investigations Report 2016-5048

Version 1.1, October 2016 


\title{
U.S. Department of the Interior SALLY JEWELL, Secretary
}

\section{U.S. Geological Survey Suzette M. Kimball, Director}

\author{
U.S. Geological Survey, Reston, Virginia: 2016 \\ Revised: October 2016 (ver. 1.1)
}

\begin{abstract}
For more information on the USGS - the Federal source for science about the Earth, its natural and living resources, natural hazards, and the environment-visit http://www.usgs.gov or call 1-888-ASK-USGS.

For an overview of USGS information products, including maps, imagery, and publications, visit http://store.usgs.gov.
\end{abstract}

Any use of trade, firm, or product names is for descriptive purposes only and does not imply endorsement by the U.S. Government.

Although this information product, for the most part, is in the public domain, it also may contain copyrighted materials as noted in the text. Permission to reproduce copyrighted items must be secured from the copyright owner.

Suggested citation:

Kozar, M.D., and Paybins, K.S., 2016, Assessment of hydrogeologic terrains, well-construction characteristics, groundwater hydraulics, and water-quality and microbial data for determination of surface-water-influenced groundwater supplies in West Virginia (ver. 1.1, October 2016): U.S. Geological Survey Scientific Investigations Report 2016-5048, 55 p., http://dx.doi.org/10.3133/sir20165048.

ISSN 2328-031X (print)

ISSN 2328-0328 (online) 


\section{Contents}

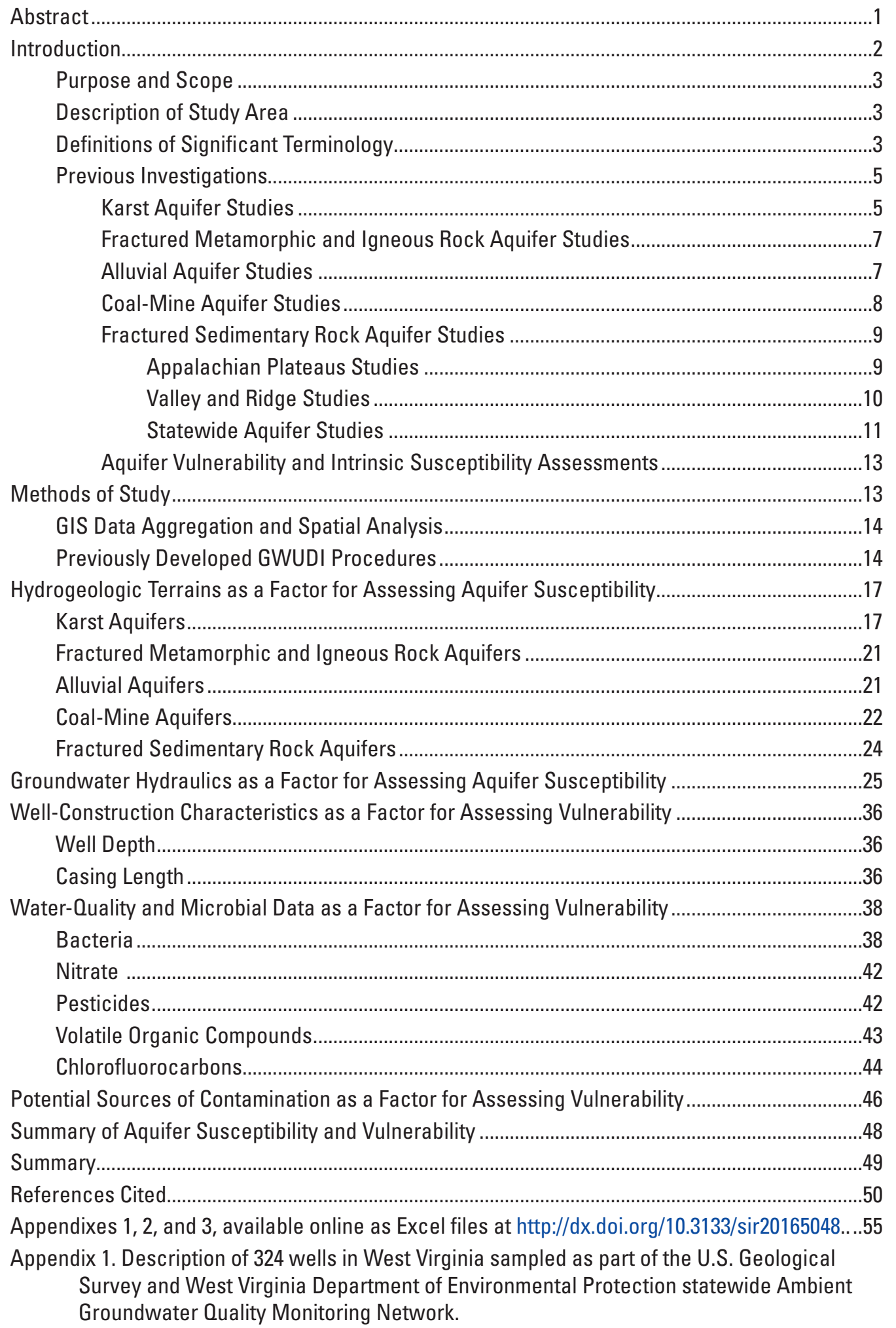


Appendix 2. Description of wells in West Virginia, including casing length and well depth, that are part of the U.S. Geological Survey Groundwater Site Inventory database with Escherichia coli, fecal coliform, and total coliform data that are stored in the U.S. Geological Survey Water-Quality database.

Appendix 3. Permit data for public groundwater supplies in West Virginia with accompanying counts of number of potential sources of contamination within the respective sourcewater-protection area for each public groundwater supply source.

\section{Figures}

1. Map showing physiographic provinces and major hydrogeologic terrains (aquifers) in West Virginia

2. Map showing major aquifers, locations of production wells and springs, and groundwater systems in West Virginia that have been classified as groundwater under direct influence of surface water by the West Virginia Bureau for Public Health

3A. Map showing major geologic formations in West Virginia (Figure $3 A$ available online at http://dx.doi.org/10.3133/sir20165048)

$3 B$. Map showing major geologic formations in the study area of the Blue Ridge Physiographic Province U.S. Geological Survey National Water Quality Assessment study in Virginia and North Carolina (Figure $3 B$ available online at http://dx.doi. org/10.3133/sir20165048)

4. Map showing distribution of current and abandoned underground coal mines in West Virginia and locations of production springs or wells that tap these underground mines, with production springs and wells that tap other aquifers

5. Boxplot showing distribution of transmissivity for coal-bearing bedrock groups and formations in West Virginia

6. Schematic cross sections showing water-level contours for $A$, gaining and $B$, losing streams.

7. Schematic cross sections showing hydraulic gradient $A$, towards a stream, $B$, towards a pumping well deriving recharge solely from the aquifer, and $C$, a pumping well that is deriving recharge both from the aquifer and from a nearby stream.

8. Map showing calibrated heads and 5-year time-of-travel paths to wells completed in alluvial deposits bordering the Ohio River in the Parkersburg and Vienna areas, Wood County, West Virginia.

9. Schematic cross sections showing hydraulic gradient $A$, towards a stream, $B$, induced recharge to an aquifer as a result of rising stream stage, and $C$, over topping of an aquifer by flood waters

10. Maps showing example of how $A$, groundwater levels and $B$, water-table contours can be used to determine $C$, direction of groundwater flow.

11. Map showing simulated water levels for hydrologic conditions respective of the 70th percentile flow duration in layer 2 representing the Pocahontas No. 3 abandoned coal-mine aquifer of the groundwater-flow model developed for the Elkhorn area, McDowell County, West Virginia. 
12. Map showing simulated drawdown in the Leetown area, West Virginia, for $A$, pre-existing pumping conditions during a drought and $B$, resulting from the addition of production wells 87 and 88 pumping at 50 and 100 gallons per minute during a drought.

13. Map showing simulated potentiometric surface and generalized directions of groundwater flow for average hydrologic conditions in the Opequon Creek Watershed area, Virginia and West Virginia.

14. Schematic cross sections showing $A$, hypothetical high hydraulic conductivity in a well showing a broad shallow cone of depression and $B$, hypothetical low hydraulic conductivity in a well showing a much deeper and narrower cone of depression .........35

15. Graph showing relation of fecal coliform, fecal streptococcus, total coliform, and E. coli bacteria to well depth for selected wells in West Virginia

16. Graph showing relation of total coliform, fecal coliform, fecal streptococcus, and E. coli bacteria to length of well casing for selected wells in West Virginia............37

17. Graph showing relation of fecal coliform, fecal streptococcus, and E. coli bacteria to length of well casing for selected wells in West Virginia

18. Map showing distribution of total coliform bacteria in West Virginia's major aquifers, 1993-2008

19. Map showing distribution of fecal coliform bacteria in West Virginia's major aquifers, 1993-2008

20. Map showing distribution of E. coli bacteria in West Virginia's major aquifers, 1993-2008.

21. Map showing distribution of nitrate plus nitrite in West Virginia's major aquifers, 1993-2008

22. Map showing distribution of pesticides in West Virginia's major aquifers, 1993-2008

23. Map showing distribution of volatile organic compounds in West Virginia's major aquifers, 1993-2008

24. Chart showing conceptual qualitative assessment of intrinsic susceptibility and aquifer vulnerability for various hydrogeologic terrains in West Virginia

\section{Tables}

1. Flow chart showing the West Virginia Department of Health and Human Resources criteria for determination of groundwater supplies under direct influence of surface water.

2. Summary of aquifer transmissivity data for West Virginia, showing typical transmsissivity values for respective aquifers differentiated by geologic age and aquifer type

3. Summary of data derived from geographic information system analyses of datasets on land use and potential sources of contamination pertaining to individual source-water-protection areas in West Virginia . 


\section{Conversion Factors}

\begin{tabular}{|c|c|c|}
\hline Multiply & By & To obtain \\
\hline \multicolumn{3}{|c|}{ Length } \\
\hline foot $(\mathrm{ft})$ & 0.3048 & meter $(\mathrm{m})$ \\
\hline mile (mi) & 1.609 & kilometer (km) \\
\hline inch (in.) & 25.4 & millimeter $(\mathrm{mm})$ \\
\hline \multicolumn{3}{|c|}{ Area } \\
\hline square mile $\left(\mathrm{mi}^{2}\right)$ & 259.0 & hectare (ha) \\
\hline square mile $\left(\mathrm{mi}^{2}\right)$ & 2.590 & square kilometer $\left(\mathrm{km}^{2}\right)$ \\
\hline \multicolumn{3}{|c|}{ Volume } \\
\hline inch per year (in/yr) & 25.4 & millimeter per year $(\mathrm{cm} / \mathrm{yr})$ \\
\hline gallon (gal) & 3.785 & liter $(\mathrm{L})$ \\
\hline gallon (gal) & 0.003785 & cubic meter $\left(\mathrm{m}^{3}\right)$ \\
\hline gallon (gal) & 3.785 & cubic decimeter $\left(\mathrm{dm}^{3}\right)$ \\
\hline million gallons per day (Mgal/d) & 3.785 & cubic meter $\left(\mathrm{m}^{3} / \mathrm{d}\right)$ \\
\hline cubic inches $\left(\mathrm{in}^{3}\right)$ & 16.387 & milliliter $(\mathrm{mL})$ \\
\hline cubic inches $\left(\mathrm{in}^{3}\right)$ & 16.387 & cubic centimeters $\left(\mathrm{cm}^{3}\right)$ \\
\hline \multicolumn{3}{|c|}{ Flow rate } \\
\hline cubic foot per second $\left(\mathrm{ft}^{3} / \mathrm{s}\right)$ & 0.02832 & cubic meter per second $\left(\mathrm{m}^{3} / \mathrm{s}\right)$ \\
\hline gallons per minute & 0.06309 & liters per second $(\mathrm{L} / \mathrm{s})$ \\
\hline \multicolumn{3}{|c|}{ Specific Capacity } \\
\hline gallons per minute per foot $[(\mathrm{gal} / \mathrm{min}) / \mathrm{ft}]$ & 0.2070 & liters per second per meter $[(\mathrm{L} / \mathrm{s}) / \mathrm{m}]$ \\
\hline \multicolumn{3}{|c|}{ Transmissivity } \\
\hline feet squared per day $\left(\mathrm{ft}^{2} / \mathrm{d}\right)$ & 0.09290 & meter squared per day $\left(\mathrm{m}^{2} / \mathrm{d}\right)$ \\
\hline \multicolumn{3}{|c|}{ Hydraulic Conductivity } \\
\hline foot per day $(\mathrm{ft} / \mathrm{d})$ & 0.3048 & meter per day $(\mathrm{m} / \mathrm{d})$ \\
\hline \multicolumn{3}{|c|}{ Radioactivity } \\
\hline picocurie per liter $(\mathrm{pCi} / \mathrm{L})$ & 0.037 & becquerel per liter $(\mathrm{Bq} / \mathrm{L})$ \\
\hline
\end{tabular}

Temperature in degrees Celsius $\left({ }^{\circ} \mathrm{C}\right)$ may be converted to degrees Fahrenheit $\left({ }^{\circ} \mathrm{F}\right)$ as follows:

${ }^{\circ} \mathrm{F}=\left(1.8 \mathrm{x}^{\circ} \mathrm{C}\right)+32$ 
Temperature in degrees Fahrenheit $\left({ }^{\circ} \mathrm{F}\right)$ may be converted to degrees Celsius $\left({ }^{\circ} \mathrm{C}\right)$ as follows:

${ }^{\circ} \mathrm{C}=\left({ }^{\circ} \mathrm{F}-32\right) / 1.8$

Vertical coordinate information is referenced to the North American Vertical Datum of 1988 (NAVD 88).

Horizontal coordinate information is referenced to the North American Datum of 1983 (NAD 83).

Elevation, as used in this report, refers to distance above the vertical datum.

Specific conductance is given in microsiemens per centimeter at 25 degrees Celsius $\left(\mu \mathrm{S} / \mathrm{cm}\right.$ at $\left.25^{\circ} \mathrm{C}\right)$.

Concentrations of chemical constituents in water are given either in milligrams per liter (mg/L) or micrograms per liter $(\mu \mathrm{g} / \mathrm{L})$.

*Transmissivity: The standard unit for transmissivity is cubic foot per day per square foot times foot of aquifer thickness $\left[\left(\mathrm{ft}^{3} / \mathrm{d}\right) / \mathrm{ft}^{2}\right] \mathrm{ft}$. In this report, the mathematically reduced form, foot squared per day $\left(\mathrm{ft}^{2} / \mathrm{d}\right)$, is used for convenience.

Specific conductance is given in microsiemens per centimeter at 25 degrees Celsius $\left(\mu \mathrm{S} / \mathrm{cm}\right.$ at $\left.25^{\circ} \mathrm{C}\right)$.

\section{Abbreviations}

$\begin{array}{ll}\text { AMBGWMN } & \text { Ambient Groundwater-Quality Monitoring Network } \\ \text { CFCs } & \text { Chlorofluorocarbons } \\ \text { GWR } & \text { Groundwater Rule } \\ \text { GWSI } & \text { Groundwater Site Inventory database } \\ \text { GWUDI } & \text { Groundwater under direct influence of surface water } \\ \text { HBSL } & \text { Health-based screening level } \\ \text { MCHM } & \text { 4-methlycyclohexane methanol } \\ \text { MCL } & \text { Maximum contaminant level } \\ \text { NAWQA } & \text { National Water-Quality Assessment } \\ \text { NPDES } & \text { National Pollutant Discharge Elimination System } \\ \text { NWIS } & \text { National Water Information System } \\ \text { SMCL } & \text { Secondary maximum contaminant level } \\ \text { SWIGS } & \text { Surface-water-influenced-groundwater supply } \\ \text { SWTR } & \text { Surface Water Treatment Rule } \\ \text { WVBPH } & \text { West Virginia Bureau for Public Health } \\ \text { WVDEP } & \text { West Virginia Department of Environmental Protection } \\ \text { WVDHHR } & \text { West Virginia Department of Health and Human Resources }\end{array}$





\title{
Assessment of Hydrogeologic Terrains, Well-Construction Characteristics, Ground water Hydraulics, and Water- Quality and Microbial Data for Determination of Surface- Water-Influenced Groundwater Supplies in West Virginia
}

\author{
By Mark D. Kozar and Katherine S. Paybins
}

\section{Abstract}

In January 2014, a storage tank leaked, spilling a large quantity of 4-methylcyclohexane methanol into the Elk River in West Virginia and contaminating the water supply for more than 300,000 people. In response, the West Virginia Legislature passed Senate Bill 373, which requires the West Virginia Department of Health and Human Resources (WVDHHR) to assess the susceptibility and vulnerability of public surfacewater-influenced groundwater supply sources (SWIGS) and surface-water intakes statewide. In response to this mandate for reassessing SWIGS statewide, the U.S. Geological Survey (USGS), in cooperation with the WVDHHR, Bureau of Public Health, Office of Environmental Health Services, compiled available data and summarized the results of previous groundwater studies to provide the WVDHHR with data that could be used as part of the process for assessing and determining SWIGS.

Existing geologic, hydrologic, well-construction, waterquality, and other related data and information from previous U.S. Geological Survey (USGS) hydrogeologic studies and the USGS National Water Information System (NWIS) database, in conjunction with data from the West Virginia Bureau for Public Health (WVBPH) Department of Health and Human Resources (WVDHHR) and the West Virginia Department of Environmental Protection database and files, were collected, compiled, and analyzed to help the WVDHHR to better assess public groundwater supply wells that may meet the definition of a surface-water-influenced- groundwater supply (SWIGS).

In this study, measures of intrinsic susceptibility, which are characterized by the physical properties that affect the ease with which water moves through the unsaturated zone and, subsequently, into the saturated zone within an aquifer, showed that karst limestone aquifers are the aquifers most intrinsically susceptible to contamination within the State of West Virginia. Karst limestone aquifers are present within Cambrian- and Ordovician-age formations within West Virginia's eastern panhandle and in Mississippian-age limestones within the Greenbrier River valley. Solution development within these limestone aquifers allows rapid recharge and flow of groundwater within the aquifer, both of which allow surface contaminants to easily enter the aquifer and travel long distances in a short period of time.

Alluvial aquifers bordering the Ohio River in western West Virginia are also potentially highly susceptible to contamination because these alluvial aquifers can receive significant recharge from the adjacent Ohio River. Any potential contaminants that may be present in the river have the potential to enter the aquifer and contaminate wells completed within the sand and gravel alluvial sediments within which the wells are completed. These same alluvial sediments, however, help to retard the movement of bacteria and other potentially pathogenic organisms, such as Cryptosporidia and Giardia lamblia, into the aquifer. As a result, samples from alluvial aquifers bordering the Ohio River and elsewhere within the State do not commonly test positive for indicator bacteria, such as total coliform, fecal coliform, or Escherichia coli (E. coli). The alluvial sediments do not, however, provide assimilative capacity with respect to water soluble compounds such as nitrate and certain volatile and semi-volatile organic compounds. Therefore, the Ohio River alluvial aquifers are highly susceptible to organic compounds present in the river or on the land surface near a well. These aquifers are also susceptible to nitrate contamination from fertilizers, pesticides, and manure, which are commonly used on the fertile agricultural soils present on terraces along the Ohio River.

Abandoned-coal-mine aquifers, which are typically used as a source of groundwater in southern West Virginia, are moderately susceptible to contamination. The vast network of voids from mine entries provide vast storage for groundwater in abandoned mine aquifers, and fracturing of overburden strata, which is common in areas of past or current mining, can allow rapid infiltration of contaminants to the aquifer. Where streams cross over below-drainage underground coal mines, there is an increased potential for contamination of coalmine aquifers. As a result, above-drainage underground coal 
mines, those mines that are present at an elevation above local tributary drainage, are probably less susceptible to contamination than are below-drainage underground coal mines. Public groundwater supplies in abandoned coal mines need to be evaluated on a case-by-case basis to assess the potential for recharge of contaminated surface water to enter below-drainage underground coal-mine aquifers and to assess potential hydraulic conductivity to nearby surface-water bodies, such as lakes, ponds, rivers, or streams.

Fractured-rock aquifers compose an additional major type of aquifer within the State of West Virginia. Owing to their low permeability and their typically small groundwater capture areas, fractured-rock aquifers within the State of West Virginia typically have low susceptibility to contamination. However, there are exceptions, and wells completed in fractured-rock aquifers that are in close proximity to streams may be adversely affected by induced recharge from the stream. Where such systems are present, frequent bacterial testing of the source water can be used to ascertain the potential for microbial contamination of the aquifer.

Intrinsic susceptibility alone does not fully predict whether or not a well is vulnerable to contamination, only that the hydrogeologic terrain is suitable for rapid transport of pathogenic organisms or chemical compounds to and within the aquifer. However, contaminants may or may not be present in the recharge water to an individual well or well field. Therefore, an assessment of potential contaminant sources, such as nearby gas wells, landfills, underground storage tanks, above ground storage tanks, major transportation corridors, surface or underground coal mines, and flood plains, is needed to assess vulnerability. The assessments need to be conducted on a case-by-case basis or, as has been done in this study, by collecting and compiling the number of potential contaminant sources that may be present in the source-water-protection area for an individual public groundwater supply source.

Groundwater public-supply systems in areas of high intrinsic susceptibility and with a large number of potential contaminant sources within the recharge or source-waterprotection area of individual wells or well fields are potentially vulnerable to contamination and probably warrant further evaluation as potential SWIGS. However, measures can be taken to educate the local population and initiate safety protocols and protective strategies to appropriately manage contaminant sources to prevent release of contaminants to the aquifer, therefore, reducing vulnerability of these systems to contamination. However, each public groundwater supply source needs to be assessed on an individual basis. Data presented in this report can be used to categorize and prioritize wells and springs that have a high potential for intrinsic susceptibility or vulnerability to contamination.

\section{Introduction}

In March 2014, the West Virginia legislature passed Senate Bill No. 373. The legislation was enacted in response to a major chemical spill in January 2014 of 4-methylcyclohexane methanol (MCHM) from a leaking storage tank on the banks of the Elk River. The spill contaminated the drinking-water supply for more than 300,000 people in the Kanawha River valley region in Kanawha County, West Virginia, and adjacent counties. Major provisions of the legislation (1) mandate regulation of the public water systems by the Commissioner of the Bureau for Public Health; (2) provide for entry into and evaluations of water systems; (3) require source-waterprotection plans and specified contents of the plans; (4) require assessment and monitoring of plans; (5) require the Bureau for Public Health to coordinate a long-term medical study of potential health effects of MCHM; (6) mandate continuance of the wellhead and source-water-protection grant program; (7) continue a grant fund to provide water source protection; (8) revise the Water Resources Protection and Management Act; and (9) establish the Aboveground Storage Tank Act, which requires the secretary of the West Virginia Department of Environmental Protection to compile an inventory of above ground storage tanks in the state and requires inventories of sources of selected contaminants in the zones of critical concern of certain public water systems. Section 16-1-9c (a) of the legislation, which requires update or completion of source-water-protection plans, specifies that on or before July 1,2016 , each existing public water utility that draws and treats water from a surface-water supply source or a surface-waterinfluenced groundwater-supply source shall submit to the commissioner an updated or completed source-water-protection plan for each public water system plant intake to protect public water supplies from contamination. In section 16-1-2 (19) a "public surface-water-influenced groundwater supply source" is defined as "a source of water supply for a public water system which is directly drawn from an underground well, underground river or stream, underground reservoir, or underground mine, and the quantity and quality of the water in that underground supply source is heavily influenced, directly or indirectly, by the quantity and quality of surface water in the immediate area."

Because the legislation was written in response to a chemical spill on the Elk River, and because the term "surface water in the immediate area" is loosely defined, the term "Surface-Water-Influenced Groundwater Supply" (SWIGS) within this report has a broader definition that includes a groundwater supply that is heavily influenced by water recharging the well from adjacent rivers, streams, ponds, lakes, irrigation water, or even precipitation that pools at the surface. Therefore, 
SWIGS, as used in this report, includes water from shallow surface processes, such as crop irrigation, and (or) natural recharge from precipitation. This approach was taken because in alluvial and karst aquifers rapid infiltration of precipitation or flow of pooled surface overland runoff into alluvial sediments or sinkholes can be a source of contaminants entering alluvial and karst aquifers. This report, which was written by the U.S. Geological Survey (USGS) in cooperation with the West Virginia Department of Health and Human Resources (WVDHHR ), provides information to better assess the quality of water from production wells that meet the definition of heavily surface-water-influenced groundwater supply, hereafter referred to as SWIGS.

Within this report, two primary sources of data are assessed to aid the WVDHHR in determining whether particular groundwater systems should be identified as SWIGS. The first is the natural hydrogeologic properties of the aquifers related to their transmissivity and permeability, hereafter referred to as "intrinsic susceptibility." More transmissive aquifers, such as karst and alluvial aquifers, are more easily contaminated by surface contaminants than are less transmissive aquifers such as fractured-rock aquifers. The second is the vulnerability of an aquifer and is based on well-construction properties, including casing length and well depth, and the chemical and microbial quality of groundwater with respect to constituents, such as indicator bacteria, nitrate, pesticides, volatile organic compounds (VOCs), and chlorofluorocarbons (CFCs). Potential sources of contaminants are compiled to aid in determining sites that have a high number of potential sources of contaminants in the designated source-water-protection areas of individual wells, springs, or well fields.

\section{Purpose and Scope}

The purpose of this report is to present a discussion of available geologic, hydrologic, well-construction, water-quality, and other related data and information from past USGS hydrogeologic studies, from the USGS National Water Information System (NWIS) database, the WVDHHR database and files, and the West Virginia Department of Environmental Protection (WVDEP) database and files. These data may be used by the WVDHHR to better assess the quality of groundwater supply withdrawn by production wells that meets the definition of a SWIGS. As the definition of SWIGS leaves room for interpretation, it is imperative that determinations of potential SWIGS are based on the best available scientific data. This report summarizes information from more than 40 previous studies related to the intrinsic susceptibility of aquifers in West Virginia to contamination via surface water, presents an evaluation of the relation of well construction to well vulnerability, provides direct observation of vulnerability of aquifers and wells using existing water-quality data, and provides a tally of the number and type of contaminant sources within the source-water-protection area for production wells or springs. A discussion is presented on basic groundwater hydraulics, such as hydraulic gradient, hydraulic conductivity, and fundamental groundwater-flow processes, which are important in assessing the potential movement (or lack thereof) of a potential contaminant towards a production well.

\section{Description of Study Area}

The study area for this investigation is the entire State of West Virginia, which includes parts of the Appalachian Plateaus, Valley and Ridge, and Blue Ridge Physiographic Provinces (fig. 1). Aquifers are divided into five basic hydrogeologic terrains, each with their own intrinsic susceptibility to contamination. A hydrogeologic terrain is a lithologic type of rock or rocks with distinct similar hydraulic properties and groundwater-flow processes. The aquifer types and five terrains consist of (1) alluvial aquifers bordering the Ohio and Kanawha Rivers and other major tributary streams; (2) karst aquifers in the Shenandoah River valley of West Virginia's eastern panhandle and in the Greenbrier River valley, and thin limestone outcrops in the Valley and Ridge Physiographic Province; (3) fractured crystalline metamorphic and igneous rock aquifers in a thin band within the Blue Ridge in Jefferson County, in the easternmost part of West Virginia; (4) abandoned underground coal-mine aquifers in southern West Virginia; and (5) fractured sandstone, shale, coal, and associated sedimentary-rock aquifers in most of the State, including parts of the Appalachian Plateaus and Valley and Ridge Physiographic Provinces. These important aquifers and their intrinsic susceptibility to contamination (or lack there of) are discussed in more detail in the "Assessment of Hydrogeologic Terrains as a Factor for Assessing SWIGS" section of this report.

\section{Definitions of Significant Terminology}

In order for the reader to understand the process by which data are analyzed and presented within this report, it is critical to first define several terms of uncommon usage in hydrogeologic literature. These terms have been subject to misinterpretation; therefore, the terms (1) "surface-water-influenced groundwater supplies (SWIGS)," (2) "intrinsic susceptibility," (3) "vulnerability," and (4) "hydrogeologic terrains" will be defined here to avoid confusion.

The term "public surface-water-influenced groundwater supply source," as defined in West Virginia Senate Bill 373, section 16-1-2 (19), is "a source of water supply for a public water system which is directly drawn from an underground well, underground river or stream, underground reservoir or underground mine, and the quantity and quality of the water in that underground supply source is heavily influenced, directly or indirectly, by the quantity and quality of surface water in the immediate area." The definition is subject to interpretation, so representatives of the USGS met with representatives of the WVDHHR to clarify the State's definition of the term for this study. During the discussion, the representatives of the WVDHHR indicated that the framers of the legislation intended to protect groundwater resources not only from 


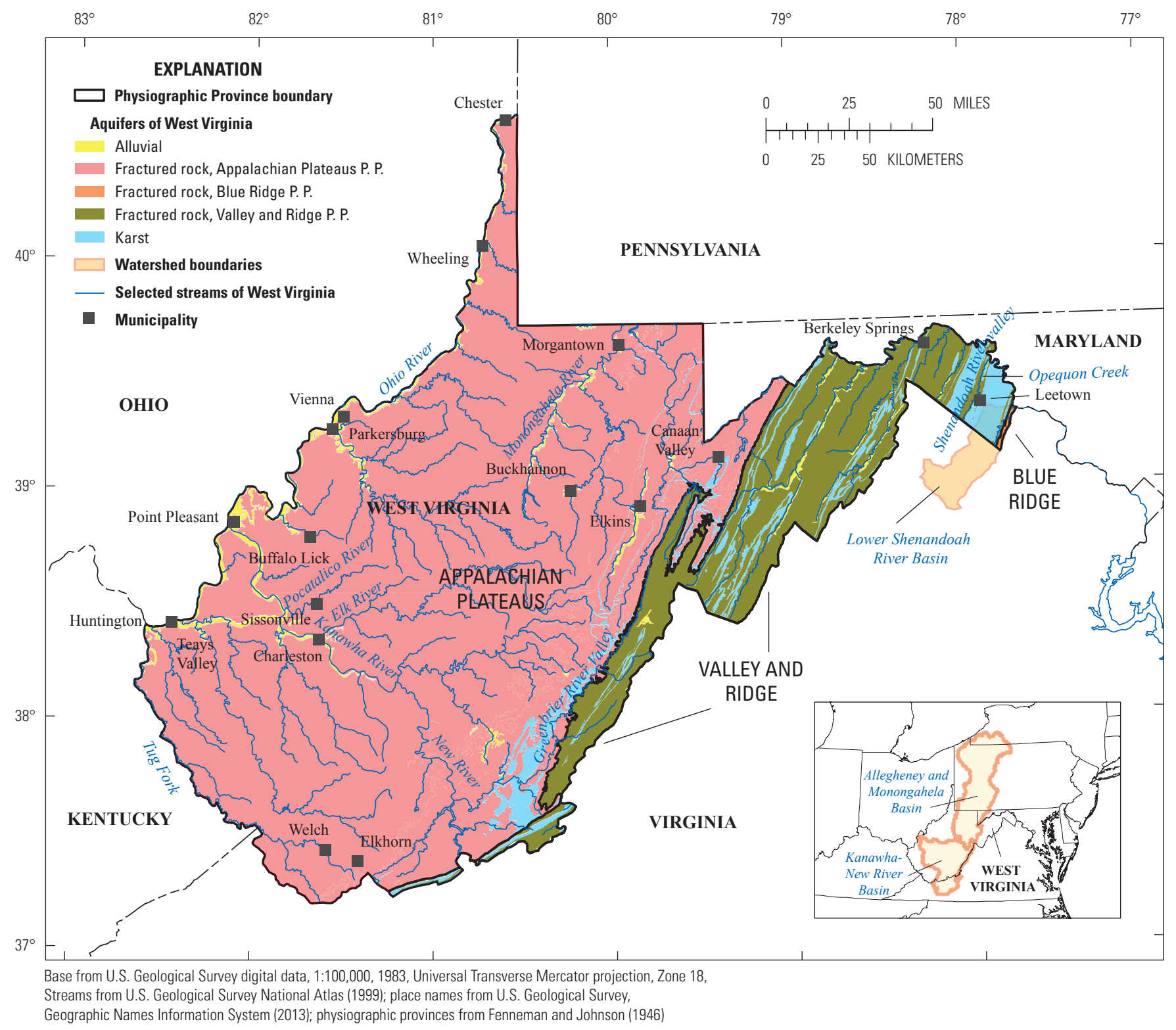

Figure 1. Physiographic provinces and major hydrogeologic terrains (aquifers) in West Virginia. (P. P., Physiographic Province)

potential contamination which may be induced by infiltration into pumped wells from nearby streams, lakes, or ponds, but any surface-water source, including precipitation that falls on the ground surface, and accidental releases of contaminantladen water, such as storage tank failures or leaks, that spills onto the surface and potentially may be transported into and contaminate an aquifer. The phrase "in the immediate" area was also interpreted to include non-point sources of contamination such as nitrates and pesticides that can occur in agricultural areas.

Intrinsic susceptibility is defined in USGS Circular 1224 (Focazio and others, 2002) and further discussed in USGS Circular 1385 (Eberts and others, 2013). Intrinsic susceptibility is characterized by the physical properties that influence the ease with which water moves through the unsaturated zone and within an aquifer. Intrinsic susceptibility is an important aspect of vulnerability because infiltrating water can contain contaminants, and subsurface travel times can influence whether reactions affecting contaminant concentrations can take place before the water is discharged from the aquifer. Intrinsic susceptibility depends on the thickness and hydraulic properties of the unsaturated zone, which affect recharge rates to the aquifer. It also depends on the aquifer hydraulic properties (hydraulic conductivity, porosity, and transmissivity) and hydraulic gradients, which affect flow rates within the aquifer and discharge rates from the aquifer. A brief discussion of the applications of Darcy's Law and groundwater flow, with respect to the terms in the groundwater-flow equation, 
is presented in the "Groundwater Hydraulics" section of this report. Collectively, recharge rates, discharge rates, the ability of the aquifer material to transmit water, and the size and shape of an aquifer contribute to the length of time groundwater will reside in an aquifer. Thus, groundwater age - the time elapsed since water entered an aquifer system - is a measure of intrinsic susceptibility.

Within this report, intrinsic susceptibility is discussed in terms of hydrogeologic terrains. These hydrogeologic terrains differ significantly with respect to recharge rate, groundwater age and residence times, lithology, hydraulic properties, and water quality. The terrains are a major factor to be considered by the WVDHHR in assessing SWIGS. In addition, statewide assessments of groundwater age based on chlorofluorocarbons (McCoy and Kozar, 2007) and water quality have been conducted using data collected as part of USGS National Water-Quality Assessments (NAWQA) in the Kanawha/New River and Allegheny/Monongahela River watersheds, and using additional data collected by the USGS, WVDHHR, and WVDEP as part of the statewide Ambient Groundwater-Quality Monitoring Network (AMBGWMN). The water-quality data from the statewide AMBGWMN, which were collected from 324 wells, predominantly production wells (appendix 1), also are a major source of data that may be used by the WVDHHR in determining SWIGS.

Groundwater vulnerability as discussed in USGS Circular 1385 (Eberts and others, 2013) depends on three factors.

- Contaminant sources (contaminant input) in the recharge area to production wells or springs It is important to document whether there are point or nonpoint sources of contamination in the recharge area to production wells or springs. Point sources could include above or underground storage tanks; chemical processing plants; and transportation corridors, such as railroads or interstate highways. Non-point sources could include agricultural land, golf courses, irrigation waters, or large densities of septic systems.

- Chemical and physical processes in the subsurface that affect contaminant concentrations in an aquifer (contaminant mobility and persistence) Such processes may include redox processes, denitrification, biodegradation, other biogeochemical changes, and filtering of microbes by sediments.

- Intrinsic susceptibility The ease with which water and contaminants can travel to and within an aquifer.

Hydrogeologic terrains, as used within this report, refer to bedrock or alluvial aquifers within a physiographic province that share similar hydraulic properties, groundwater-flow processes, recharge rate, groundwater age and residence time, lithology, and water quality. Hydrogeologic terrains are correlative to aquifers and have been identified as such in previous USGS literature (Schwietering, 1981; Puente, 1985). The term "hydrogeologic terrains" is used in this report only when referring to stratigraphy or geologic formation, and the term "aquifers" is used when referring to the overall water-bearing formations. The three factors related to production well vulnerability can be assessed by understanding (1) the sources of recharge that contribute water to a well and the contaminants associated with the recharge - a measure of contaminant input; (2) the geochemical conditions encountered by water drawn into a well - a measure of contaminant mobility and persistence; and (3) the groundwater-age, which is a mixture of different waters that blend (or mix) in a well - a measure of intrinsic susceptibility.

\section{Previous Investigations}

Hydrogeologic studies have been completed that can be used to assess groundwater under the influence of surface water and groundwater affected by surface or shallow nearsurface land use, and that may provide significant insight into the factors needed to assess SWIGS. Studies were conducted for various aquifers within the State, including but not limited to the karst aquifers in West Virginia's eastern panhandle within the Shenandoah River valley, the alluvial aquifers along the Ohio River, abandoned underground coal-mine aquifers, and fractured-rock aquifers. Other studies are statewide and retrospective in scope. The water-quality data from these studies provide direct observations of aquifer or well vulnerability.

\section{Karst Aquifer Studies}

Owing to the ease with which karst aquifers may be contaminated by shallow groundwater and surface land-use activities, such as agriculture and septic system return flows, numerous investigations of the water quality of karst aquifers in Jefferson, Berkeley, and Morgan Counties in West Virginia's eastern panhandle have been conducted. The first significant karst study was conducted in Jefferson and Berkeley Counties in the late 1950s (Bieber, 1961). Bieber's study was the first to document potentially high concentrations of nitrate in groundwater in the region, although only 1 of 41 wells sampled (2.4 percent) had nitrate concentrations that equaled or exceeded the current U.S. Environmental Protection Agency (EPA) 10-milligrams per liter (mg/L) of nitrate as nitrogen $(\mathrm{N})$ maximum contaminant level (MCL) drinking water standard. At the time of Bieber's study, the dominant land use was agricultural.

Early studies often report nitrate in terms of nitrate as $\mathrm{NO}^{3}$, with an older 45-mg/L MCL drinking water standard. This includes data from Bieber (1961) and Hobba (1981a and 1976). Within this report, all references are with respect to the current $10-\mathrm{mg} / \mathrm{L}$ as N MCL drinking water standard; data have been converted and are referenced accordingly.

Follow-up studies ensued to address potential bacterial and nitrate contamination in karst aquifers in the eastern panhandle. In 1976, a water-quality study in Berkeley County, West Virginia, (Hobba, 1976) showed that 6 of 345 $(1.7 \%)$ wells sampled had concentrations of nitrate exceeding 
Assessment for Determination of Surface-Water-Influenced Groundwater Supplies in West Virginia

drinking water standards, and 3 of $15(20 \%)$ wells sampled contained either fecal coliform or fecal streptococcus bacteria. A potentiometric-surface (water-table) map of Berkeley County, based on water levels measured in 336 wells, was developed and published as part of the Hobba (1976) study. The potentiometric-surface map is especially useful and aids assessment of recharge areas to production wells and springs. Three successful dye tracer tests were conducted for the study ( 1 additional test was not successful) by injection of fluorescent dyes into sinkholes and monitoring of resurgence points at springs and streams in the area surrounding the injection point. The dye tracer tests were not summarized in the report, but are part of a statewide compilation of dye tracer tests for West Virginia (Jones, 1997). According to Jones (1997), on the basis of fluorometric dye tracer tests, groundwater velocities in Berkeley County ranged from 32 to 155 feet per day (ft/d) with a median of $71 \mathrm{ft} / \mathrm{d}$ for the fracture-dominated diffuseflow part of the karst aquifer and from 703 to $1,879 \mathrm{ft} / \mathrm{d}$ with a median of 1,139 ft/d for the conduit-dominated part of the karst aquifer. Rapid flow in conduit-dominated parts of the karst aquifer system can allow transport of contaminants over a broad area in a very short period of time; therefore, the karst aquifer systems are highly susceptible to contamination.

In 1981, a similar study conducted for adjacent Jefferson County, West Virginia, (Hobba, 1981a) showed that 24 of 192 $(12.5 \%)$ wells sampled had concentrations of nitrate exceeding drinking water standards, and 23 of $30(77 \%)$ wells sampled contained either fecal coliform or fecal streptococcus bacteria. The two early studies by Hobba $(1976,1981$ a) were focused on documenting nitrate contamination in the heavily agricultural region, but the sporadic bacteria testing indicated an even greater likelihood of bacterial contamination. A potentiometric-surface map of Jefferson County, developed and published as part of the study, is based on water levels measured in 201 wells. Two dye tracer tests were attempted for the study, but neither were successful. Results of six dye tracer tests conducted in Jefferson County are summarized by Jones (1997). According to Jones (1997), groundwater velocities in Jefferson County, which are based on flow to 14 resurgence points, ranged from 50 to $150 \mathrm{ft} / \mathrm{d}$ with a median flow rate of $120 \mathrm{ft} / \mathrm{d}$; similar velocities were determined for Berkeley County.

As a result of sparse bacterial data from previous studies, follow-up studies were conducted in Jefferson County in 1988 (Kozar and others, 1991) and in Berkeley County in 1989 and 1990 (Shultz and others, 1995) to further investigate the extent of nitrate and bacterial contamination, and to assess whether concentrations were increasing over time. The study by Kozar and others (1991) shows that nitrate concentrations in Jefferson County were higher than documented in the earlier Hobba (1981a) study. Of 62 wells and 8 springs sampled, samples from $18(26 \%)$ exceeded the $10-\mathrm{mg} / \mathrm{L}$ as $\mathrm{N}$ drinking water standard for nitrate, and samples from 37 (53\%) contained one or more colonies of fecal coliform bacteria per 100 milliliters $(\mathrm{mL})$ of sample. Samples from 48 of 69 wells and springs $(70 \%)$ contained one or more colonies of fecal streptococcus bacteria. Five dye tracer tests were conducted for the study, but only 3 were successful. On the basis of the three successful fluorometric dye tracer tests conducted, groundwater velocities in Jefferson County ranged from 30 to $185 \mathrm{ft} / \mathrm{d}$ for the fracture-dominated diffuse-flow part of the karst aquifer, and velocities were at least $840 \mathrm{ft} / \mathrm{d}$ for conduit flow along a fault with enhanced permeability due to dissolution of limestone along the fault.

A 1993 study of groundwater availability and quality in Berkeley County (Shultz and others, 1995) found that samples from 54 percent of wells collected in June through October 1989 tested positive for fecal streptococcal bacteria, and 24 percent tested positive for fecal coliform bacteria. Samples collected during the cold winter months of March and December 1989 and March of 1990 contained lower concentrations of bacteria. Samples from only 17 percent of wells tested positive for fecal streptococcal bacteria, and samples from only 7.4 percent of wells tested positive for fecal coliform bacteria. Cold air temperatures and minimal applications of manure on agricultural fields in winter months may be responsible for the lower detection rate of bacteria in winter months.

In June 2000, 50 additional wells in Berkeley County in the eastern panhandle of West Virginia were sampled for indicator bacteria (Mathes, 2000). The primary objective of the study was to assess the bacterial quality of water with respect to the density of septic systems in a 5-acre circular area around the wells sampled. No relation was found between bacteria concentrations and septic density. Of the 50 wells sampled, however, 31 (62\%) contained total coliform bacteria, 16 (32\%) contained Escherichia coli (E. coli), and 15 (30\%) contained fecal coliform bacteria. The preponderance of bacteria in karst aquifers in the eastern panhandle is direct evidence of the intrinsic susceptibility and vulnerability of the aquifer.

An intensive hydrogeologic study of the Leetown area (Kozar and others, 2007a and b) showed that the groundwaterflow system responds quickly to precipitation, and groundwater recharge occurs quickly. The karst aquifer is dominated by a shallow epikarstic layer-a shallow layer of heavily weathered, highly fractured, and solutionally enlarged bedrock and regolith, which ranges in typical thickness from 22 to $61 \mathrm{ft}$ with a median thickness of $40 \mathrm{ft}$. Groundwater recharge to this epikarstic layer is nearly instantaneous, which indicates a significant vulnerability to contamination of the aquifer from any land-use activity at the surface. Groundwater-flow velocities in the karst aquifer are rapid, ranging from 12 to $540 \mathrm{ft} / \mathrm{d}$ during relatively dry periods and from 1,000 to $6,500 \mathrm{ft} / \mathrm{d}$ after heavy recharge events. Heavy recharge events force water to rise from the lower, more diffuse, less solutionally enlarged karst part of the groundwater system, where groundwater-flow velocities are slow, upwards into the shallow epikarstic layer where groundwater-flow velocities can be very rapid. Flushing of groundwater through the shallow epikarstic layer is common after heavy storms. Groundwater-flow models were developed for the Leetown area beginning with a groundwater-flow model of the Hopewell Run watershed near Leetown (Kozar and others, 2007a). 
Additional groundwater-flow models were developed for the Opequon Creek watershed, of which Hopewell Run is a tributary (Kozar and Weary, 2009), and for the entire Shenandoah River valley (Yager and others, 2008). These models are useful for understanding the water budgets for the karst aquifers in the Shenandoah River valley, and for assessing the potential recharge areas to production wells and springs in the region. As a result of the body of work that has been conducted in the eastern panhandle of West Virginia, the karst aquifers of the region are considered the aquifers most intrinsically susceptible to contamination within the State of West Virginia.

In 1973, a report summarizing a study of the hydrology of limestone karst in Greenbrier County, West Virginia, was published (Jones, 1973). Jones (1973) conducted multiple groundwater tracer tests using fluorometric dyes, mapped major karst groundwater catchments, described significant springs and karst features, and discussed the karst hydrology of Greenbrier County. The study found, as is common for karst watersheds, that groundwater catchment areas do not necessarily coincide with topographic watershed divides. Dye tracer tests completed in the Greenbrier County study, along with additional tracer tests completed for other studies are summarized by Jones (1997). On the basis of the Jones (1997) summary of 20 dye resurgence points from 15 dye tracer tests, groundwater-flow velocities for the karst aquifer in Greenbrier County are much faster than those for Jefferson and Berkeley Counties, West Virginia, ranging from 560 to 10,800 ft/d with a median of 1,914 ft/d. Such high median groundwater-flow velocities are more characteristic of a conduit-dominated karst groundwater-flow system than a diffuse-flow-dominated karst groundwater-flow system, such as in Jefferson and Berkeley Counties. As such, the karst hydrogeologic setting in the Mississippian-age Greenbrier Group limestone in the Greenbrier River valley (fig. 1) can be considered highly susceptible to contamination, and is possibly the most intrinsically susceptible aquifer in West Virginia.

A compilation of the caves and karst of West Virginia (Dasher, 2012) identified similar Greenbrier Group limestone karst in the Appalachian Plateaus Physiographic Province, in parts of Monroe, Pocahontas, and Pendleton Counties in West Virginia and to a lesser extent in other counties in the eastern part of West Virginia. As such, limestones of the Greenbrier Group that crop out in other areas of West Virginia can produce similar karst features and may have the rapid groundwater-flow rates characteristic of conduit-dominated karst groundwater-flow systems. The Karst Hydrology Atlas of West Virginia (Jones, 1997) summarizes dye tracer tests for Monroe and Pocahontas Counties, the second and third most significant outcrop areas of the Greenbrier Group in West Virginia. Data compiled from the atlas for 13 resurgence points indicate a range of groundwater-flow velocities from 1,320 to $5,680 \mathrm{ft} / \mathrm{d}$ with a median of 2,350 ft/d for Monroe County, West Virginia, and a range of groundwater-flow velocities from 240 to $52,800 \mathrm{ft} / \mathrm{d}$ with a median of $5,700 \mathrm{ft} / \mathrm{d}$ for Pocahontas County. The Monroe County groundwater velocities are similar to those for Greenbrier County, indicating a conduit-dominated flow system. Groundwater velocity estimates for Pocahontas County seem to indicate a dual porosity system similar to that of Jefferson and Berkeley Counties, but both counties are considered highly intrinsically susceptible to contamination. Few tracer test data are available for the areas with minor outcroppings of karst limestone formations.

\section{Fractured Metamorphic and Igneous Rock Aquifer Studies}

Aquifers in fractured metamorphic and igneous rocks of the Blue Ridge Physiographic Province in West Virginia compose only a very small surficial area in the easternmost extent of West Virginia in Jefferson County, along the mountain separating Virginia from West Virginia (fig. 1). However, limited water-quality data for Blue Ridge metamorphic and igneous aquifers in West Virginia (Kozar and others, 1991) and for similar aquifers farther south in North Carolina and Virginia (Kozar and others, 2001) indicate that Blue Ridge fracturedrock aquifers are especially susceptible to elevated levels of naturally occurring radon-222, a carcinogenic radioactive gas linked to lung cancer (Otton, 1992). Radon is derived from the radioactive decay process of uranium; uranium and other radioactive elements are common in igneous and metamorphic rocks (Otton, 1992). Only three wells were sampled for radon in the Blue Ridge Physiographic Province in Jefferson County, West Virginia; concentrations of radon were 2,300; 3,100; and 8,700 picocuries per liter ( $\mathrm{pCi} / \mathrm{L}$ ), all exceeding the EPA proposed MCL drinking water standard of $300 \mathrm{pCi} / \mathrm{L}$ (Kozar and others, 1991).

A USGS NAWQA study of 30 wells in the Blue Ridge Physiographic Province in North Carolina and Virginia (Kozar and others, 2001) found 26 of 30 wells sampled (87\%) had concentrations of radon in excess of the proposed $300 \mathrm{pCi} / \mathrm{L}$ drinking water standard. In 10 of the 30 wells sampled (33\%), the concentrations exceeded the proposed alternate maximum contaminant level of $4,000 \mathrm{pCi} / \mathrm{L}$. The NAWQA study also found bacterial contamination of groundwater. Eleven of 29 wells sampled (38\%) tested positive for the presence of total coliform bacteria, although none tested positive for the presence of fecal coliform or $E$. coli bacteria.

\section{Alluvial Aquifer Studies}

Numerous alluvial aquifer studies have been conducted in the past, mostly to assess the resource with respect to the quantity of water available for public and industrial groundwater supplies. One of the first studies of alluvial aquifers conducted in West Virginia was a study of groundwater conditions along the Ohio River at Parkersburg, West Virginia (Jeffords, 1945). Radial collector wells, or "Ranney Wells" as they are often referred to, are commonly used by large public suppliers and industry along the Ohio river. These collector wells are designed to use existing alluvial sediments and well screens as 
a pre-filter to remove contaminants, such as bacteria, Cryptosporidia, and Giardia lamblia (Gidley, 1952). The collector wells have lateral arms that extend beneath the river bed and are designed to pull water from alluvial deposits in a large area beneath streams. For the Parkersburg water plant, which withdraws on average nearly 4.8 million gallons per day (Mgal/d) of water from radial collector wells, as much as 75 percent of the water pumped from the wells is induced recharge from the Ohio River (Kozar and McCoy, 2004).

Of 63 wells sampled for nitrate, none exceeded the MCL drinking water standard of $10 \mathrm{mg} / \mathrm{L}$ as $\mathrm{N}^{1}$, established by the EPA. However, 16 of 29 wells sampled for iron (55\%) exceeded the 300-microgram per liter $(\mu \mathrm{g} / \mathrm{L})$ EPA secondary maximum contaminant level (SMCL) drinking water standard for iron. Jeffords (1945) found the water temperature of groundwater in alluvial wells in Parkersburg closely mimicked water temperatures in the Ohio River, although there was a potential lag of days to months in some wells. The similar temperatures indicate that the Ohio River is a potential source of recharge to alluvial wells completed in glacial outwash sediments along the Ohio River. Bacterial analyses of raw well water were reviewed for the study and indicated that bacterial contamination of the groundwater did occur, although the frequency of detection was low. Jeffords (1945) concludes that the sand and gravel aquifer serves as a natural filter pack to filter out most of the bacteria and other pathogens in Ohio River water that eventually percolates through the sand and gravel aquifer to production wells.

Alluvial sediments along the Kanawha River are not as coarse grained as those along the Ohio River and contain a higher percentage of fluvially deposited sand compared to Ohio River alluvial deposits, which contain a larger percentage of glacial outwash gravel (Doll and others, 1960; Wilmoth, 1966). As a result, wells tapping the alluvial deposits along the Kanawha River likely induce less recharge of stream water than those located along the Ohio River. Alluvial aquifers along other smaller streams and tributaries in West Virginia typically have a much higher silt and clay content than sand and (or) gravel and typically are not tapped as a water source for public supply.

Most of the previous studies of alluvial aquifers in the State did not obtain water-quality data. However, these studies were very effective in documenting the sand and gravel composition of river valley aquifers and river terraces (Jeffords, 1945; Kazmann and others, 1943; Simard, 1989). For Ohio River alluvial deposits, coarse-grained glacial outwash composed of sands and gravels are separated by lenses of silt and clay. These alternating sequences of sand and gravel and silt and clay lenses have been proposed to act as large filters, effectively filtering out microbial contaminants, microscopic particulates, and pathogens such as Giardia lamblia and Cryptosporidia from nearby streams (Jeffords, 1945). This filtering of microbes and particulates likely has a substantial effect on

${ }^{1}$ The MCL of $10 \mathrm{mg} / \mathrm{L}$ as $\mathrm{N}$ is equivalent to $45 \mathrm{mg} / \mathrm{L}$ as nitrate. water quality, given that studies using groundwater-flow models to estimate recharge to production wells along the Ohio River indicate that from 0 to more than 75 percent of water derived from alluvial aquifers along the Ohio River originates as infiltration of river water from the Ohio River (Kozar and McCoy, 2004).

\section{Coal-Mine Aquifer Studies}

Numerous hydrogeologic and water-quality studies have been conducted by the USGS in cooperation with the WVDEP, the WVDHHR, and the West Virginia Geological and Economic Survey (WVGES). A 1981 study of abandoned coal mines in West Virginia used as a source of water for public and domestic supplies (Lessing and Hobba, 1981) found that 72 public water systems pumped more than $7 \mathrm{Mgal} / \mathrm{d}$ of water from abandoned-coal-mine aquifers and served approximately 81,600 people. The same study estimated that if just one-half of the abandoned underground coal mines in West Virginia were flooded or partially flooded, the total volume of water potentially stored in underground coal mines could be as much as 250 billion gallons.

A similar study was conducted for the WVDEP by the WVGES in 2012 to assess the potential amount of water stored in abandoned underground coal mines (McColloch and others, 2012). This study used more robust and quantitative methods, especially geographic information system (GIS) analyses, in conjunction with a detailed statewide mine map database and structure contours for major coal seams, to provide much more quantitative estimates of water availability than were possible during the earlier study by Lessing and Hobba (1981). Structure contours for the various mapped mines were compared with digital elevation models to determine whether the mines are present at an elevation above that of local tributary streams (above drainage) or if they are present below the elevation of perennial streams (below drainage). The study documented that 99 mines in 14 major coal seams are likely totally filled with water (flooded), and an additional 532 mines are likely partially flooded.

A study of abandoned mine workings near Welch, West Virginia, was conducted (Ferrell, 1992) to describe the hydrologic characteristics of the flooded and abandoned mines and determine sources of recharge and interconnection of water from various sources, including adjacent coal mines, precipitation, and induced recharge from the Tug Fork River. The Tug Fork River is adjacent to the abandoned mines from which the city of Welch derives its water and is at a higher elevation than some parts of the mines. A key finding of that study was that recharge from the Tug Fork River can be induced when water within the mine aquifer falls to certain levels. Many communities in headwater streams of the Tug Fork drainage area are un-sewered or lack proper septic systems, and the discharge of raw sewage into tributary streams is common (West Virginia Department of Environmental Protection, 2008). Thus, induced recharge is a potential source of bacterial contamination to below-drainage abandoned-coal-mine aquifers. 
A study of abandoned-underground coal mines in Upshur County, West Virginia, was conducted by the USGS to determine whether the mines were a suitable source of water to augment existing supplies during times of drought (Hobba, 1987). Although it was determined that sufficient quantities of water were available from the abandoned-undergroundcoal-mine aquifers to augment existing supplies in times of drought, it was also determined that the water would require extensive treatment to remove nuisance constituents such as iron, manganese, and sulfide.

Studies by the USGS of the effects of conventional mining on the hydrology of selected mined watersheds in West Virginia (Hobba, 1981b) and the results of long-wall coal mining (Shultz, 1988) indicate that mining has the capacity to greatly increase fracturing of overburden strata, thereby artificially inducing additional recharge to underground aquifers, including abandoned-coal-mine aquifers and fractured-rock aquifers. Subsidence fracturing of overburden and overlying streambeds was shown to increase aquifer transmissivity, decrease discharge of springs in overlying strata, alter water levels in overlying and underlying strata, and induce recharge to abandoned-underground-coal-mine aquifers. Loss of water from overlying streams is a potential source of recharge to underlying aquifers but also is a potential source of contamination to abandoned-underground-coal-mine aquifers.

The USGS NAWQA program conducted a study (McAuley and Kozar, 2006) to compare and contrast groundwater quality of domestic wells downgradient from reclaimed surface coal mines with the water quality of equivalent wells in unmined areas. The study area for the investigation was the low-sulfur coal fields of southern West Virginia within the Kanawha and New River watersheds and the high sulfur coal fields in northern West Virginia and southwestern Pennsylvania in the Allegheny and Monongahela River watersheds. Groundwater within about $500 \mathrm{ft}$ of mined areas had median concentrations of constituents indicative of mine drainage (sulfate, iron, manganese, calcium, magnesium, turbidity, and specific conductance) that were significantly greater than the median concentrations of these constituents in water samples from wells in unmined areas. However, concentrations of mine drainage constituents were equal to or less than concentrations at unmined sites more than $1,000 \mathrm{ft}$ downgradient from the reclaimed surface mines.

The USGS partnered with the WVDEP, the WVDHHR, and the WVGES to conduct a study of abandoned abovedrainage coal mines in the Elkhorn area, McDowell County, West Virginia (Kozar and others, 2012). The primary objective of the study was to better understand groundwater-flow processes, recharge, and water quality of above-drainage abandoned-underground-coal-mine aquifers and to develop a quantitative numerical groundwater-flow model for the abovedrainage abandoned-underground-coal-mine aquifer. Even though the coal mines in this area are above drainage at most locations, some parts of the mines that are at locally lower elevations are flooded. The Pocahontas No. 3 coal seam is the primary source of water for public supply in the Elkhorn area.
The groundwater -flow model was used to assess the area contributing recharge to the abandoned-coal-mine aquifer, which discharges from mine outfalls (also called adits, which are mine entries from land surface) at elevations approximately 80 to $100 \mathrm{ft}$ above the elevation of nearby streams, such as Elkhorn Creek and North Fork. Such mine outfalls are the primary source of water for public supply in the Elkhorn area and are gravity fed to downgradient water treatment plants for chlorination and distribution. The comprehensive study was one of the first studies to prove the utility of groundwater-flow models for assessing recharge areas to production wells and mine outfalls in a complex above-drainage coal-mine aquifer. The study, based on dye tracer tests, documented that rapid recharge of precipitation and groundwater flow in stressrelief fractures is possible on a scale of days to weeks but that abandoned-underground-coal-mine aquifers can have a much older component of groundwater. The older component of groundwater was determined to be approximately 26 years. Interbasin transfer of groundwater within abandoned mine workings is also possible.

\section{Fractured Sedimentary Rock Aquifer Studies}

Most of the aquifers in the Appalachian Plateaus and Valley and Ridge Physiographic Provinces of West Virginia are composed of fractured sedimentary rock. The USGS, in cooperation with the WVDEP, the WVDHHR, and the WVGES, has also conducted a number of hydrogeologic investigations in the fractured-rock areas of the State. For clarity of discussion, the results of fractured-rock aquifer studies in the Appalachian Plateaus Physiographic Province will precede discussions of similar fractured-rock aquifer studies in the Valley and Ridge Physiographic Province.

\section{Appalachian Plateaus Studies}

Investigation of groundwater resources in Harrison County, West Virginia, (Nace and Bieber, 1958) found groundwater hardness ranged from soft to very hard, and iron (5 of 6 wells sampled, or 83\%) concentrations typically exceeded the $300-\mu \mathrm{g} / \mathrm{L}$ SMCL. Well yields of 1-5 gallons per minute (gal $/ \mathrm{min}$ ) were common, and yields in excess of $25 \mathrm{gal} / \mathrm{min}$ were rare. A more robust sampling of groundwater in neighboring Monongalia County (Carlston, 1958) showed similar patterns of water quality; water hardness ranged from soft to very hard. Iron concentrations equaled or exceeded the SMCL drinking water standard in 19 of 47 (40\%) wells sampled. Nitrate exceeded the $10-\mathrm{mg} / \mathrm{L}$ as nitrogen $(\mathrm{N}) \mathrm{MCL}$ in only 1 of 186 wells sampled $(0.5 \%)$. Well yields in Monongalia County were higher than those in neighboring Harrison County, ranging from less than 1 to $400 \mathrm{gal} / \mathrm{min}$ and equaling or exceeding $10 \mathrm{gal} / \mathrm{min}$ in 56 of $213(26 \%)$ wells sampled. In Ohio County in the northern panhandle of West Virginia, of 12 wells sampled, none exceeded the SMCL of $300 \mu \mathrm{g} / \mathrm{L}$ for iron or the $10 \mathrm{mg} / \mathrm{L}$ as N MCL for nitrate, and only 1 well 
sampled had a concentration of manganese that exceeded the 50- $\mu \mathrm{g} / \mathrm{L}$ SMCL (Robison, 1964).

A study of bacterial contamination of rural drinking-water supplies was conducted in Preston County, West Virginia (Sworobuk, 1984). Of 155 groundwater samples collected from springs, dug wells and drilled bedrock wells, 87 percent contained 1 or more colonies of total coliform bacteria, 48 percent contained fecal coliform bacteria, and 61 percent contained fecal streptococcus bacteria. Springs and dug wells are typically much more prone to contamination than are drilled bedrock wells and are no longer encouraged for use as a residential water supply [Title 64 Legislative Rule-Series 46 (64CSR46)]. Therefore, when only the drilled bedrock wells are considered, 33 of $66(50 \%)$ wells sampled contained 1 or more colonies of total coliform bacteria per $100 \mathrm{~mL}$ of sample, 10 of $47(21 \%)$ contained 1 or more colonies of fecal coliform bacteria, and 11 of $26(42 \%)$ contained 1 or more colonies of fecal streptococcus bacteria. Although total coliform is ubiquitous in the environment, high concentrations of fecal coliform and fecal streptococcus bacteria indicate that the shallow fractured-rock aquifers in Preston County, West Virginia, are potentially vulnerable to fecal contamination from human or animal sources.

Salty groundwater at shallow depths is a known problem in certain parts of West Virginia. Maps showing depth to saline groundwater, based on data reported for oil and gas permits (Foster, 1980), indicate that saline water can occur at depths of $500 \mathrm{ft}$ or less below land surface in the western part of West Virginia near the Ohio River. Naturally occurring salt springs in that area were used as a source of salt by native Americans and early settlers and is one factor that led to the eventual development of the chemical industry in the Kanawha River valley (Bain, 1970). Campbell's Creek in Kanawha County, Buffalo Lick in Braxton County, and the Burning Springs Anticline in Wood and Wirt Counties (Bain, 1970) are areas where saline water and hydrocarbons may be found at shallow depths. The Pocatalico watershed in Jackson, Kanawha, and Roane Counties north of Sissonville in south-central West Virginia has a long history of excessive salt concentrations in surface water and shallow groundwater, possibly owing to early gas development from the Poca gas field and natural processes (Bain, 1970).

In a study of the fractured-rock aquifers of the Canaan Valley area in Tucker County West Virginia (Kozar, 1996), 50 groundwater samples were collected and analyzed for a broad range of constituents including common ions, trace metals, indicator bacteria, and pesticides. Most of the constituents did not exceed EPA drinking water standards. However, iron and manganese concentrations exceeded the $300 \mu \mathrm{g} / \mathrm{L}$ and $50 \mu \mathrm{g} / \mathrm{L}$ SMCLs in 2 and 20 percent of samples analyzed, respectively. Radon was more problematic because concentrations exceeded the $300-\mathrm{pCi} / \mathrm{L}$ proposed $\mathrm{MCL}$ in 67 percent of the wells and springs sampled. Radon concentrations were higher in the Pocono and Pottsville/Mauch Chunk Group rocks, which contain dark shales, than in the rocks of the Greenbrier Group, which is composed primarily of limestone.
Dark shales are a primary source of radioactive minerals in bedrock within West Virginia and elsewhere (Otton, 1992). Fecal coliform and fecal streptococcus bacteria were detected at varying concentrations in 22 and 48 percent of sites sampled, respectively. Well yields in the Canaan Valley area were higher than is typical for most fractured-rock aquifers in West Virginia; mean well yields were 23.3, 22.5, and $19.2 \mathrm{gal} / \mathrm{min}$ for the Pottsville/Mauch Chunk Group, Greenbrier Limestone, and Pocono Group, respectively. These higher than typical well yields may partially explain the high occurrence of indicator bacteria detected in the groundwaters because the aquifers in Canaan Valley are more permeable than other fractured-rock aquifers throughout the State and, therefore, may have the capacity to receive recharge over a much larger area than is common for most fractured-rock aquifers within West Virginia. Soils are typically very thin in areas of Mauch Chunk Group and especially overlying the Pottsville Group bedrock; thin soils provide little filtration of any surface contaminants that may be present.

The USGS NAWQA program conducted groundwater and surface-water quality appraisals for most of the larger river watersheds in the United States. One such study was a groundwater-quality appraisal of the Kanawha River watershed in the Appalachian Plateaus Physiographic Province of West Virginia (Sheets and Kozar, 2000). Thirty wells were sampled for a broad suite of constituents, including major ions, indicator bacteria, nutrients, trace elements, radon, pesticides, and volatile organic compounds (VOCs). This was one of the first studies that investigated the occurrence of VOCs in groundwater in fractured-rock aquifers of West Virginia. Total coliform bacteria were detected in 5 of the $30(17 \%)$ wells sampled for the study; E. coli was detected in 1 of the wells (3\%) sampled. The iron and manganese findings were similar to those in other fractured-rock aquifers in West Virginia, with 12 of $30(40 \%)$ wells sampled having concentrations of iron exceeding the 300- $\mu \mathrm{g} / \mathrm{L}$ SMCL drinking water standard and 17 of 30 wells sampled (57\%) exceeding the $50-\mu \mathrm{g} / \mathrm{L}$ SMCL for manganese. None of the samples contained concentrations in excess of the $10 \mathrm{mg} / \mathrm{L}$ as N MCL for nitrate or the MCLs for the various pesticides and VOCs analyzed. Nitrates, pesticides, and VOCs were not detected at concentrations exceeding established drinking water standards or health-based screening levels (HBSLs), where such standards exist. Arsenic was found in concentrations exceeding the $10-\mu \mathrm{g} / \mathrm{L} \mathrm{MCL}$ at 4 of the $30(13 \%)$ wells sampled.

\section{Valley and Ridge Studies}

Results of an intensive hydrogeologic and water-quality study of Ordovician- to lower Mississippian-age fracturedrock aquifers in Morgan County, West Virginia, which is in the Valley and Ridge Physiographic Province (Boughton and McCoy, 2006), indicate water-quality issues similar to those in other fractured-rock investigations in the Appalachian Plateaus Physiographic Province of West Virginia. In 1984, the State of West Virginia passed legislation (West Virginia Bureau for Public Health, 1984) that mandated homeowners apply for 
a permit and well drillers submit a report upon completion of drilling of residential water wells. In 2008, (West Virginia Department of Health and Human Resources, 2008) legislation was passed that mandated grouting of all new residential water wells. Grouting requirements had already been in place in Jefferson, Berkeley, and Morgan Counties as a result of county health ordinances established to better protect residential wells from contamination, especially with respect to bacterial contaminants and associated pathogens that may be associated with fecal wastes. Boughton and McCoy (2006) targeted only wells of recent completion for sampling as part of the Morgan County study to determine whether the new grouting and well-construction regulations were a factor in reducing bacterial contamination of groundwater. Samples collected from 91 wells and 8 springs were analyzed for a broad range of constituents, including common ions, trace metals, nutrients, indicator bacteria, and radon-222. Of the 91 wells sampled, $42(46 \%)$ tested positive for total coliform bacteria, but only $5(5 \%)$ tested positive for fecal coliform bacteria, and only $2(2 \%)$ tested positive for E. coli bacteria. Total coliform bacteria are ubiquitous in the environment and may not necessarily be the best indicator of potential pathogens in groundwater. The presence of fecal coliform or E. coli bacteria, however, are regarded as indicators for the presence of potential pathogens, as they generally originate in the intestines of warm-blooded animals. A plot of total coliform bacteria versus the ratio of casing length to well depth showed far fewer bacteria in wells with high ratios of casing length to well depth (Boughton and McCoy, 2006). The relatively low concentrations of fecal coliform (5\%) and E. coli ( $2 \%)$ detected in the wells sampled in Morgan County indicate that grouting of wells, installation of longer casings, and drilling of deeper water wells to avoid zones of shallow contaminated water near the surface may help to reduce bacterial contamination. In contrast, wells sampled in previous studies had relatively high concentrations of indicator bacteria and did not meet current (2008) well-grouting requirements.

Iron and manganese were also common constituents in groundwater in Morgan County as in other areas of fractured rock in West Virginia; 32 percent of wells sampled had iron concentrations in excess of the $300-\mu \mathrm{g} / \mathrm{L}$ SMCL, and 60 percent of groundwater samples collected for manganese analysis had concentrations in excess of the 50- $\mu \mathrm{g} / \mathrm{L}$ SMCL. None of the wells sampled had concentrations of arsenic or nitrate in excess of the $10-\mu \mathrm{g} / \mathrm{L}$ or $10-\mathrm{mg} / \mathrm{L}$ MCL drinking water standards, respectively. Radon-222, a radioactive and carcinogenic gas known to cause lung cancer (Otton, 1992), was found in concentrations exceeding the proposed $300-\mathrm{pCi} / \mathrm{L}$ MCL drinking water standard in 56 percent of the wells sampled.

A study of the hydrology and geochemistry of thermal springs in the Appalachians (Hobba and others, 1979) indicated that, in the Valley and Ridge Physiographic Province, there is a potential for groundwater to percolate along steeply dipping geologic structures such as anticlines and synclines to depths of $1,000 \mathrm{ft}$ or more below land surface. This can result in groundwater circulating to sufficient depths to be geothermally heated; discharging water then emanates as warm springs in fractured sedimentary-rock aquifers within the Valley and Ridge Physiographic Province. Warm springs discharge near the town of Bath, better known as Berkeley Springs in Morgan County.

A study of the hydrologic effects of stress-relief fracturing in Appalachian valleys (Wyrick and Borchers, 1981) showed that most of the groundwater flow in fractured rocks of the Appalachian Plateaus occurs in fractures that formed as a result of isostatic rebound (a result of stress relief from erosion of overlying sediments). Isostatic rebound causes upward arching of bedding planes in valley bottoms and subsequent vertical stress-relief fractures in valleys and hillsides. Thus, the control of groundwater flow in fractured rocks in the Appalachian Plateaus Physiographic Province is primarily a shallow phenomenon, whereas control of flow in fractured rocks in the Valley and Ridge Physiographic Province can be a much deeper process. Shallow fracture-flow systems are typically more vulnerable to contamination than are deeper fractureflow systems.

\section{Statewide Aquifer Studies}

Several studies have investigated groundwater conditions at a statewide level. The first of such statewide studies investigated groundwater for major drainage watersheds within the State (Schwietering, 1981). Schwietering (1981) used a framework for analysis similar to that used in this report - that of intrinsic susceptibility, based on certain broad hydrogeologic terrains, such as fractured-rock aquifers in the Valley and Ridge and Appalachian Plateaus Physiographic Provinces, alluvial aquifers along major river valleys, and coal-mine aquifers. Igneous and metamorphic fractured-rock aquifers of the Blue Ridge Physiographic Province were not included in his study owing to the minor outcrop of Blue Ridge aquifers within the State of West Virginia. Schwietering (1981) provides detailed discussion of the hydrogeologic properties of the aquifers within the State but provides only a cursory discussion of water quality, mostly with regards to water hardness, water type (based on predominant anion), and concentrations of iron.

Groundwater resources were described for West Virginia as part of a nationwide assessment of groundwater resources (Puente, 1985). Puente's (1985) classification nomenclature is similar to that of Schwietering (1981). Puente (1985) classifies aquifers into one of six primary aquifer types primarily on the basis of lithology and geologic age. Puente (1985) identifies the following six aquifer types for West Virginia: (1) Alluvial aquifers, (2) Upper Pennsylvanian aquifers, (3) Lower Pennsylvanian aquifers, (4) Mississippian aquifers, (5) Devonian and Silurian aquifers, and (6) Ordovician and Cambrian aquifers. The approach used in this investigation is similar to that of Schwietering (1981) and Puente (1985), but physiographic province and lithology, primarily carbonate or siliciclastic, were used to differentiate the Cambrian, Ordovician, Silurian, Devonian, and Mississippian aquifers on the basis of water quality. As with Schwietering (1981), Puente (1985) did not 
discuss Blue Ridge aquifers because of their small outcrop area within the State of West Virginia.

A statewide assessment of groundwater-quality data stored in the USGS NWIS database was conducted in 1998 (Mathes and others, 1998). Studies conducted by the USGS prior to the 1980s rarely investigated water quality with respect to VOCs or pesticides, and only sparsely investigated the occurrence and distribution of bacteria in groundwater within the State. Therefore, most of the data available for analysis by Mathes and others (1998) consisted of concentrations of common ions, trace elements (especially those related to acid mine drainage), and nutrients. The water-quality data were analyzed in relation to major aquifers on the basis of geologic age, principally Cambrian, Ordovician, Silurian, Devonian, Mississippian, Pennsylvanian, and Permian fractured-rock aquifers, and Quaternary-age alluvial aquifers, in all major physiographic provinces in West Virginia, except for the Blue Ridge. Analyses of water-quality data in relation to well depth also were conducted. The highest concentrations of dissolved iron and manganese were found in wells in valley settings, followed by wells on hillsides; wells on hilltops generally had lower concentrations of dissolved iron and manganese. Water hardness showed the exact opposite trend; hilltop wells generally had the hardest waters, and valley wells typically had softer waters. The median concentrations of iron in wells of various depth ranges were as follows: $0-100 \mathrm{ft}$ deep, $300 \mu \mathrm{g} / \mathrm{L} ; 101-300 \mathrm{ft}$ deep, $60 \mu \mathrm{g} / \mathrm{L}$; and more than $300 \mathrm{ft}$ deep, $35 \mu \mathrm{g} / \mathrm{L}$. Likewise, median concentrations of manganese decreased with well depth as follows: $0-100 \mathrm{ft}$ deep, $130 \mu \mathrm{g} / \mathrm{L}$; 101-300 ft deep, $47 \mu \mathrm{g} / \mathrm{L}$; and greater than $300 \mathrm{ft}$ deep,

$9 \mu \mathrm{g} / \mathrm{L}$. In contrast, median concentrations of total dissolved solids were found to increase with increasing well depth as follows: 0-100 ft deep, $310 \mathrm{mg} / \mathrm{L} ; 101-300 \mathrm{ft}$ deep, $362 \mathrm{mg} / \mathrm{L}$; and greater than $300 \mathrm{ft}$ deep, $450 \mathrm{mg} / \mathrm{L}$. Concentrations of iron and manganese in groundwater are a result of redox processes and are more common where highly oxygenated waters occur, predominantly valley settings and in shallow wells.

Water quality was also assessed in relation to major geologic units (Mathes and others, 1998) because certain geologic units contain higher than average concentrations of iron, manganese, and nitrate in excess of drinking water standards. The report did not go into detail as to specific minerals that may be responsible for the exceedances of the drinking water standards by iron and manganese. Dissolved iron concentrations exceeded the $300-\mu \mathrm{g} / \mathrm{L}$ SMCL in 61 percent of samples from wells in the Lower Pennsylvanian-age rocks and 54 percent of samples from wells completed in Middle Pennsylvanianand Devonian-age rocks. Dissolved manganese concentrations exceeded the $50-\mu \mathrm{g} / \mathrm{L}$ SMCL in 78 percent of samples from wells completed in the Lower Pennsylvanian-age rocks, 66 percent of samples from wells completed in Devonianage rocks, 57 percent of samples from wells completed in Upper Pennsylvanian-age rocks, and 58 percent of samples from wells completed in Quaternary-age alluvial deposits. Dissolved nitrate exceeded the $10-\mathrm{mg} / \mathrm{L}$ MCL in 27 percent of samples from wells completed in Cambrian-age rocks and 12 percent of wells completed in Ordovician-age rocks. Dissolved nitrate generally did not exceed drinking water standards in other hydrogeologic terrains. The major agricultural area within the State of West Virginia is present in the Shenandoah River valley in Jefferson and Berkeley Counties, an area of predominantly Cambrian- and Ordovician-age karst limestone and dolostone bedrock.

A third statewide assessment was conducted by the USGS in 2012 (Chambers and others, 2012), which summarized groundwater-quality data for West Virginia from 1993 to 2008 for the 324 wells that compose the USGS, WVDEP, and WVDHHR cooperative statewide Ambient GroundwaterQuality Monitoring Network (AMBGWMN). Data collected for the AMBGWMN included results of more intensive analyses of indicator bacteria, radon, VOCs, and pesticides than were done during the previous statewide assessments of groundwater quality. Chambers and others (2012) found that constituent concentrations were less than the MCLs in most samples. However, some samples exceeded non-enforceable SMCLs, proposed MCLs, or advisory HBSLs. HBSLs (1) are USGS non-enforceable water-quality benchmarks that can be used to supplement EPA Maximum Contaminant Levels (MCLs) and (2) determine whether contaminants found in surface-water or groundwater sources of drinking water may indicate a potential human-health concern. Radon-222 concentrations exceeded the proposed MCL of $300 \mathrm{pCi} / \mathrm{L}$ in 45 percent of 301 samples, and iron concentrations exceeded the SMCL of $300 \mu \mathrm{g} / \mathrm{L}$ in 57 percent of samples. Manganese concentrations were greater than the SMCL $(50 \mu \mathrm{g} / \mathrm{L})$ in 62 percent of samples and greater than the HBSL $(300 \mu \mathrm{g} / \mathrm{L})$ in 25 percent of the samples. Other constituents, including VOCs, pesticides, and trace elements, exceeded drinking-water criteria at much lower frequencies. The median concentrations of radon-222 in samples from Cambrian-, Ordovician-, Silurian-, Permian-, and Quaternary-age aquifers exceeded the proposed 300-pCi/L MCL. Although median radon concentrations for wells in Devonian-, Mississippian-, and Pennsylvanian-age aquifers were less than the proposed MCL, radon concentrations greater than the proposed MCL were measured in samples from aquifers of all geologic ages. The median iron concentrations for samples from Devonian- and Pennsylvanian-age aquifers were greater than the $300-\mu \mathrm{g} / \mathrm{L}$ SMCL. Iron concentrations exceeded the SMCL in aquifers of all geologic ages, except the Cambrian. Median concentrations of manganese exceeded the SMCL in samples from Devonian-, Pennsylvanian-, and Quaternary-age aquifers. As with iron, manganese concentrations were found to exceed the SMCL in at least one sample from aquifers of all geologic ages, except the Cambrian. Pesticides were detected most frequently and in higher concentrations in limestone-dominated areas (Cambrian and Ordovician age). Although most arsenic concentrations were less than the reporting level of $0.2 \mu \mathrm{g} / \mathrm{L}$, samples from 15 wells exceeded the $10-\mu \mathrm{g} / \mathrm{L}$ MCL. Arsenic concentrations exceeding the MCL were found in 6 samples collected from Pennsylvanian-age aquifers, 4 from Devonian-age aquifers, 2 from Mississippian-age aquifers, and 1 each from Silurian-, 
Permian-, and Quaternary-age aquifers. Fecal coliform bacteria were detected in 32 of 320 wells $(10 \%)$ sampled from 1993 to 2008; E. coli were detected in 8 of 90 (9\%) samples analyzed using the Colilert $(\mathrm{C}$ method (American Public Health Association and others, 2005) from 2006 to 2008. No strong spatial patterns were observed in the occurrence of fecal coliform bacteria or E. coli. However, samples from springs, which are particularly susceptible to contamination from surface activities, frequently had quantifiable concentrations of fecal coliform bacteria. Fecal coliform bacteria were detected in 67 percent of spring samples ( 6 of 9), whereas fecal coliform bacteria were detected in approximately 8 percent of well samples.

\section{Aquifer Vulnerability and Intrinsic Susceptibility Assessments}

The aquifer vulnerability assessment done for this report is based on a similar one conducted in Virginia using data collected from 1998 through 2000 (Nelms and others, 2003). The primary constituents used for the Virginia assessment were chlorofluorocarbons (CFCs), but nitrate and VOCs were used as well. The general premise of the study was that occurrence of CFCs, VOCs, and nitrate in groundwater is an indicator of young water recharging the aquifer and, therefore, is an indicator of potential aquifer vulnerability. If these compounds are found in groundwater, they may indicate that the aquifer is vulnerable to contamination by other more harmful compounds. Results of the study indicate that all the fracturedrock aquifers within the State of Virginia, including those in the Appalachian Plateaus, Valley and Ridge, Blue Ridge, and Piedmont Physiographic Provinces, are vulnerable to contamination. Only deeper aquifers within the Coastal Plain Physiographic Province are deemed not vulnerable to contamination. The study did not attempt to differentiate the degree of intrinsic susceptibility and did not investigate the occurrence of indicator bacteria as a primary constituent for determination of aquifer vulnerability. Assessment of well construction and the presence or absence of common indicator bacteria are part of the approach used to assess vulnerability within this current study.

An initial assessment of the intrinsic susceptibility of aquifers in West Virginia was done by the USGS on the basis of CFC and dissolved-gas data obtained between 1997 and 2004 (McCoy and Kozar, 2007). A total of 111 sites were sampled for CFCs as part of the cooperative West Virginia AMBGWMN and the USGS NAWQA program. CFCs are commonly used refrigerants that came into widespread use during World War II in the early 1940s. Therefore, the presence of CFCs in groundwater is an indicator of fairly young groundwater. McCoy and Kozar (2007) found on the basis of CFC data that the apparent age of groundwater in aquifers in West Virginia ranged from 5.9 to 56 years. The median ages of groundwater in Appalachian Plateaus, Valley and Ridge, and Ohio River alluvial aquifer systems were 21, 13, and 20 years, respectively. Groundwater in Blue Ridge aquifers was not assessed owing to minimal data availability. For fractured-rock aquifers in the Appalachian Plateaus, the median apparent ages of groundwater for hilltop, hillside, and valley settings were 12,14 , and 25 years, respectively. Concentrations of CFCs generally increased in the atmosphere from the 1940s through the late 2000's. Concentrations of one or more CFCs in alluvial and Valley and Ridge aquifers different from that expected within the atmosphere for a given point in time indicate potential mixing of waters of various ages. As groundwater within the State of West Virginia typically is young ( $<50$ years) or contains a young component of recharge, the potential for anthropogenic activities at the surface to adversely affect groundwater quality is high. However, comparisons of CFC determined apparent groundwater age with concentrations of selected naturally occurring constituents (common ions and trace metals) show no correlation. Only constituents of anthropogenic origin, primarily nitrate and VOCs, correlated with younger groundwater ages.

Detections of VOCs, anthropogenic contaminants, were compared to apparent age and percentage young fraction of water determined using CFC methods. Twenty-one wells with detections of VOCs were found to have water that recharged the aquifer during 1980-90; appreciable VOC detections also occurred for wells in aquifers recharged during 1970-80 (10 wells). Groundwater that recharged aquifers during four periods - after 1990, 1960-70, 1950-60, or prior to 1950 - had only 3-5 VOC detections for each decade. More stringent well casing and grouting requirements became more common in the mid to late 1980 s and thus are potentially responsible for fewer detections of VOCs after 1990. On the basis of frequency of detection of various contaminants in groundwater in West Virginia, aquifers are vulnerable to contamination from constituents of anthropogenic origin, such as nitrate from fertilizers or bacteria from septic system return flows; to a much lesser extent, aquifers are vulnerable to VOCs and pesticide contamination. Manure, which is a commonly used agricultural fertilizer, and other animal wastes at the land surface, for example feedlots or wildlife, are potential sources of nitrate and bacteria in groundwater. Although susceptibility to these contaminants can be high for certain aquifers, vulnerability of the aquifers to these constituents is only moderate (karst limestone aquifers) to low (alluvial and fractured-rock aquifers) because few of these constituents are routinely detected in groundwater within West Virginia (Chambers and others, 2012).

\section{Methods of Study}

The natural hydrogeologic factors that relate to intrinsic susceptibility, along with the anthropogenic factors that relate to vulnerability such as well construction, chemical parameters, and microbial data that may be useful for assessing surface-water-influenced groundwater supplies, were assessed in several ways. Information regarding (1) the hydrogeologic factors that relate to the intrinsic susceptibility of an aquifer, 
such as hydrogeologic terrain and well construction, (2) the factors that relate to well vulnerability, such as chemical and microbial water-quality data that represent direct observations of aquifer and well vulnerability, and (3) the potential sources of contamination to wells were compiled or assessed to aid in the evaluation of surface-water-influenced groundwater supplies. In addition, a review of the protocols and procedures initially used to determine groundwater under direct influence (GWUDI) of surface water was also conducted to determine which factors susceptible systems may have in common.

Four primary data sources were used for analyses within this study.

1. Water-quality data for 324 wells - predominantly production wells - sampled as part of the USGS, WVDEP, and WVDHHR statewide AMBGWMN (appendix 1) were brought into a geographic information system (ArcGIS) for graphical display. The data were also entered into a statistical database to assess potential trends in individual water-quality data (Chambers and others, 2012).

2. Data were retrieved for all wells ( 787 sites) with casing and well depth data that were stored in the USGS Groundwater Site Inventory (GWSI) database and that also had microbial data stored in the USGS water-quality (QWDATA) database. These data were analyzed to determine whether parameters such as well depth and length of well casing were important factors for determining SWIGS (appendix 2).

3. Data on source-water-protection areas for production wells, as delineated by the WVDHHR were provided to the USGS.

4. GIS information from the WVDEP, such as the location of 100-year flood plains, transportation corridors, streams, National Pollutant Discharge Elimination System (NPDES) sites, above-ground water tanks, underground storage tanks, hydrogeologic terrain, and coal-mine boundaries, in conjunction with the WVDHHR data for source-water-protection areas were analyzed using GIS to ascertain the potential use of these data to aid in the determination of surface-water-influenced groundwater supplies (appendix 3).

\section{GIS Data Aggregation and Spatial Analysis}

Groundwater data on public supplies in West Virginia were brought into Arc-GIS for spatial and trend analysis. The water-quality data used for the analysis were from a retrospective statewide investigation of the water quality of public groundwater supply within the State of West Virginia (Chambers and others, 2012). The groundwater wells sampled and the associated water-quality data on major ions, trace metals, naturally occurring radioactive materials, dissolved gases, and indicator bacteria were mapped and visually assessed for spatial trends by loading the data into ArcMap, a GIS tool for analysis of geospatial data.

Next, well source-water-protection areas from the WVDHHR database were intersected with additional geospatial data to assess the various types of potential sources of contamination within the source-water-protection areas (appendix 3). The resulting polygons were used to assess the presence or absence of possible sources of water-supply contamination within the source-water-protection area. The geospatial data consisted of 16 types of potential sources of contamination, including but not limited to surface-water features, streams, railroads, roads, floodways, Superfund sites, septic systems, and gas wells.

\section{Previously Developed GWUDI Procedures}

Processes previously developed by the WVDHHR and recommended by the EPA for determining groundwater under direct influence (GWUDI) of surface water were reviewed because they are similar to the procedure that the West Virginia legislature has requested for assessment of SWIGS. In 1993, the EPA established the Surface Water Treatment Rule (SWTR) to improve public health protection through control of microbial contaminants. Although primarily directed towards public surface-water supplies, the rule is also applicable to public supplies of GWUDI of surface water. Under the SWTR, disinfection is required for all public surface-water supplies and groundwater supplies deemed to be under the direct influence of surface water (EPA, 2011). With a few minor exceptions those sites also require filtration to remove potential pathogenic bacteria, viruses, Cryptosporidia, Giardia lamblia, Legionella, and other pathogens. In 2006, the EPA established the Groundwater Rule (GWR) which used a risk-based approach to identify groundwater systems that are susceptible to fecal microbial contamination (EPA, 2004, 2008a and b, 2010a, b). The GWR also requires periodic sanitary surveys (EPA, 1999) of groundwater supplies, which are based on stringent criteria. Although GWUDI sites fall under the SWTR, provisions of the GWR are useful for identifying potential GWUDI sites. Provisions of the GWR and the SWTR recommend obtaining available data and copies of hydrogeologic and water-quality studies from organizations, such as the USGS, State Geological Surveys, and other Federal, State, and local agencies, that may be used to identify sensitive hydrogeologic settings (as used in this study) and potential GWUDI sites. Data and reports useful for determining GWUDI sites include information on hydrogeologic properties of aquifers; types of aquifers; aquifers especially vulnerable to contamination, such as karst and alluvial aquifers; microbial and chemical quality of groundwater; geologic maps; aquifer maps; and other data, such as spatial distribution of CFCs and VOCs.

The EPA has several guidance documents related to implementation of the SWTR and the GWR that provide detailed discussions on requirements of the rules and methods that may be employed to comply with the rules. These 
guidance documents include the following EPA reports: (1) EPA 816-R-11-009 (Surface Water Treatment Rules; EPA, 2011), (2) EPA 816-F-10-074 (Comprehensive Surface Water Treatment Rules Quick Reference Guide: Systems Using Conventional or Direct Filtration; EPA, 2010b), (3) EPA 816-F-04-001 (Comprehensive Surface Water Treatment Rules Quick Reference Guide: Unfiltered Systems; EPA, 2004), (4) EPA 815-R-08-011 (Groundwater Rule Corrective Actions Guidance Manual; EPA, 2008b), (5) EPA 815-R-99-016 (Guidance Manual for Conducting Sanitary Surveys of Public Water Systems: Surface Water and Ground Water Under the Direct Influence (GWUDI); EPA, 1999), (6) EPA-816-F-08-029 (Groundwater Rule: a Quick Reference Guide; EPA, 2010a), and (7) EPA-815-R-07-023 (Ground Water Rule Source Water Assessment Guidance Manual; EPA, 2008a).

In 1998 the USGS was asked by the WVDHHR to provide any data and reports that were pertinent to the identification of potential GWUDI sites. At that time the USGS provided a bibliography of pertinent publications, summaries of pertinent USGS reports, and chemical and microbial data that potentially could be used to determine factors specific to the State of West Virginia for identifying GWUDI of surface water.

To conform with recommendations and guidance in the EPA documents, the WVDHHR used state-specific information provided by the USGS for the development of procedures for assessing and identifying potential GWUDI sites within the State of West Virginia. These procedures are specified in WVDHHR Guidance Memorandum \#23 Update (West Virginia Bureau for Public Health, 1999). The WVDHHR has divided groundwater public-supply systems into three classes on the basis of their vulnerability to surface-water influence. Group 1 systems are considered low risk sites and are typically transient systems with minimal distribution. Group 1 sites are evaluated on the basis of two bacteria samples of raw water collected 3-5 weeks apart. Group 2 systems are considered moderate risk sources and are typically non-community/non-transient and community systems. Group 2 systems are evaluated on the basis of 6 bacteria samples of raw water; 2 samples are collected 3-5 weeks apart during dry weather, and 4 samples are collected within a week after a rain event. Group 3 systems are considered high risk sources and are usually community systems with sources that have a potential to be contaminated, such as springs, coal mines, and wells in a karst areas. Group 3 sources are evaluated on the basis of Group 2 requirements with 4 additional bacteria samples of raw water collected on 4 different days after a second additional rain event, for a total of 10 samples. Dry weather is defined as no more than 2 inches of rain over a 7 -day period or $1 / 2$-inch or more of rain in any 24-hour period during the 7-day period. A rain event is considered any precipitation event of $1 / 2$-inch or more of rain in a 24-hour period.

Determinations of whether or not a site is considered a GWUDI are then based on the results of the bacteria tests and any temperature, turbidity, nitrate, or microbial data such as microscopic particulate analysis to identify Cryptosporidia, Giardia lamblia, and insect parts that may be present. According to requirements of the SWTR (EPA, 2011), water sources with fewer than 20 colonies per 100 milliliters (cols/100 mL) of $E$. coli bacteria and fewer than $100 \mathrm{cols} / 100 \mathrm{~mL}$ of total coliform bacteria do not require filtration, only chlorination to disinfect for bacteria and associated pathogens. WVDHHR criteria for GWUDI determination sets the threshold at greater than (>) 15 cols $/ 100 \mathrm{~mL}$ of E.coli and $>100$ cols $/ 100 \mathrm{~mL}$ of total coliform. Guidance for GWUDI determination also refers to temperature variation in the source water over the 3-5 week sampling period. Groundwater sources with water temperature variation of more than 7 degrees Fahrenheit $\left({ }^{\circ} \mathrm{F}\right)$ over the bacteria sampling period may be indicative of a GWUDI. A well with the possibility of GWUDI may require a sanitary survey to assess whether proper grout seal and casing installation requirements have been met. Additional bacteria sampling may be required on the basis of site-specific criteria if a source has a temperature variation greater than $7^{\circ} \mathrm{F}$ but no bacteria are detected in initial samples collected. Table 1 presents the GWUDI method of determination currently used by the WVDHHR. Sites identified by the WVDHHR as GWUDI sites are shown in table 1 and on figure 2.

Table 1. Flow chart showing the West Virginia Department of Health and Human Resources criteria for determination of groundwater supplies under direct influence of surface water.

$\left[>\right.$, greater than; $\leq$, less than or equal to; $\mathrm{mL} /$, milliliter; ${ }^{\circ}$, degree $]$

\begin{tabular}{|c|c|c|c|c|c|}
\hline \multicolumn{2}{|c|}{$\begin{array}{l}\text { Groundwater under } \\
\text { the direct influence } \\
\text { (GWUDI): }\end{array}$} & \multirow{2}{*}{$\begin{array}{c}\text { Are }>15 \\
\text { colonies } / 100 \mathrm{~mL} \\
\begin{array}{c}\text { E. coli bacteria } \\
\text { present? }\end{array} \\
\text { GWUDI }\end{array}$} & \multirow{2}{*}{$\begin{array}{c}\text { Are there } \leq 15 \\
\text { colonies } / 100 \mathrm{~mL} \\
\begin{array}{c}\text { E. coli bacteria } \\
\text { present? }\end{array} \\
\text { Not GWUDI }{ }^{1}\end{array}$} & \multirow{2}{*}{$\begin{array}{c}\begin{array}{c}\text { Are there }>100 \\
\text { colonies } / 100 \mathrm{~mL} \\
\text { total coliform } \\
\text { present? }\end{array} \\
\text { GWUDI }\end{array}$} & \multirow{2}{*}{$\begin{array}{c}\text { Are } \leq 100 \\
\text { colonies/100 mL } \\
\text { total coliform } \\
\text { present? }\end{array}$} \\
\hline $\begin{array}{l}\text { Does water } \\
\text { temperature vary }\end{array}$ & Yes & & & & \\
\hline
\end{tabular}

\footnotetext{
${ }^{1}$ In situations where definitive confirmation of a GWUDI is difficult to determine or rule not applicable, microscopic particulate analysis may be used to confirm whether or not a particular site is or is not considered a GWUDI.
} 


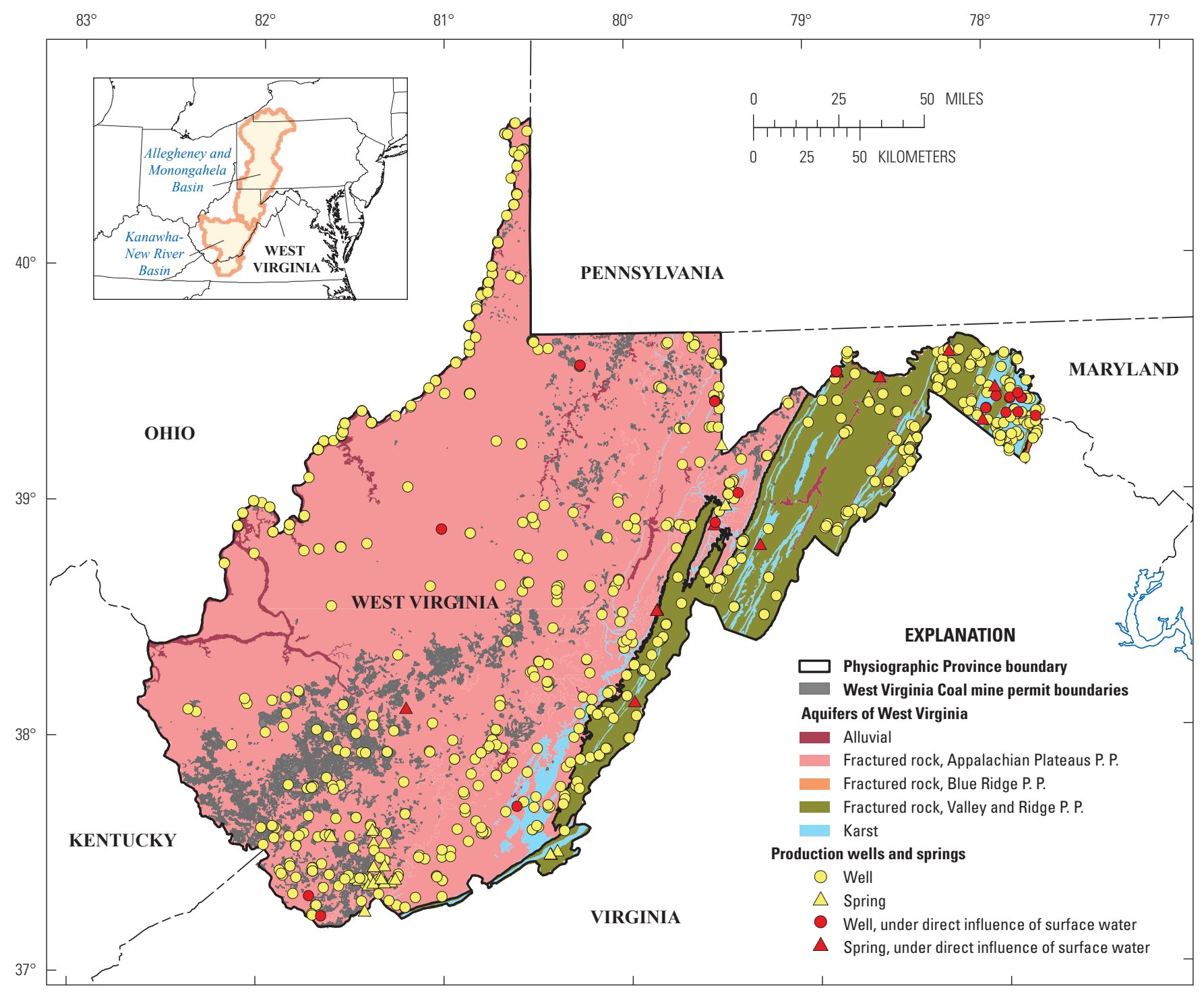

Base from U.S. Geological Survey digital data, 1:100,000, 1983, Universal Transverse Mercator projection, Zone 18,

Coal mine permit boundaries from West Virginia Department of Environmental Protection, 2014

Figure 2. Major aquifers, locations of production wells and springs, and groundwater systems in West Virginia that have been classified as groundwater under direct influence of surface water by the West Virginia Bureau for Public Health.

(P. P., Physiographic Province) 


\section{Hydrogeologic Terrains as a Factor for Assessing Aquifer Susceptibility}

Hydrogeologic terrain, a concept first applied in West Virginia by Schwietering (1981) and adopted as standard nomenclature by Puente (1985), is one of the most important factors related to assessing whether an aquifer is intrinsically susceptible to contamination from near-surface processes. Hydrogeologic terrains are bedrock or alluvial aquifers within a physiographic province that share similar hydraulic properties, groundwater-flow processes, recharge rates, groundwater ages and residence times, lithology, and water quality. They are commonly used to differentiate aquifers within West Virginia. There are three distinct physiographic provinces within the State: the Appalachian Plateaus, Valley and Ridge, and Blue Ridge (fig. 1). There are also three primary rock types and alluvial sand and gravel deposits that occur in the State and compose the principal aquifers (fig. 1): (1) fractured sedimentary rocks, consisting mostly of non-carbonate siliciclastic rocks that are primarily sandstone, siltstone, shale, mudstone, and thin limestones in the Appalachian Plateaus and the Valley and Ridge Physiographic Provinces; (2) carbonate rocks, primarily limestone and dolostone in the Valley and Ridge Physiographic Province, and to a lesser degree Mississippian-age rocks in the Appalachian Plateaus Physiographic Province, many of which have developed karst (solution features); (3) fractured metamorphic and igneous rocks in the Blue Ridge Physiographic Province in the easternmost part of West Virginia (Cardwell and others, 1968); (4) alluvial sand and gravel deposits - alluvial aquifers along the borders of some of the State's major tributaries, especially along the Ohio and Kanawha rivers within the Appalachian Plateaus Physiographic Province; and (5) abandoned-underground-coal-mine aquifers are a subset of the Appalachian Plateaus fracturedrock aquifers and provide a source of public groundwater supply in certain areas, primarily in the southern part of the State.

Geologic strata in West Virginia are composed of several formations and groups (fig. $3 \mathrm{~A}$, available online at http:// dx.doi.org/10.3133/sir20165048), ranging in age from the Cambrian through the Permian (Cardwell and others, 1968) within the three physiographic provinces. The names of the geologic formations and groups follow the nomenclature as used by the West Virginia Geologic and Economic Survey (Cardwell and others, 1968) and do not necessarily conform to USGS nomenclature. Each formation has different permeability, specific capacity, transmissivity, and topographically or structurally controlled groundwater-flow patterns that relate to the intrinsic susceptibility of the aquifer to contamination. A statewide assessment of aquifer characteristics for West Virginia (Kozar and Mathes, 2001) provides aquifer transmissivity data (summarized in table 2) that can be used to assess the potential for intrinsic susceptibility of the State's major aquifers. Generally, the more transmissive aquifers, such as the karst, alluvial, and abandoned-coal-mine aquifers within the State, have larger zones of contribution and are therefore more susceptible to contamination than are less transmissive aquifers, such as the fractured-rock aquifers, with much smaller zones of contribution. The fractured-rock aquifers also typically have lower well yields and capture water from a smaller area than the more transmissive karst, abandonedcoal-mine, and alluvial aquifers. In the following sections, hydrogeologic data and CFC data from previous studies are combined to create a summary of data that characterizes the intrinsic susceptibility of aquifers to contamination and provides direct observations of vulnerability for each hydrogeologic terrain in the State.

Thirty wells were sampled by the USGS in the Blue Ridge Physiographic Province in Virginia and North Carolina as part of USGS National Water Quality Assessment (NAWQA) programs. Due to the sparsity of data for the Blue Ridge province in West Virginia, data from the NAWQA studies in the Blue Ridge province in Virginia and North Carolina (Kozar and others, 2001) were used to augment the minimal data for the Blue Ridge province in West Virginia owing to the similarity in rock type throughout the Blue Ridge province. Rocks of the Blue Ridge province are much older and of a different type than those of the Appalachian Plateaus and Valley and Ridge Phyisographic Provinces in West Virginia, range in age from the Early Proterozoic eon to the Early Cambrian period, and are primarily composed of metamorphic and igneous rock (Nicholson and others, 2005; Dicken and others, 2005). Figure $3 B$ (fig. 3B, available online at http:// dx.doi.org/10.3133/sir20165048) illustrates the geology of the NAWQA study area in the Blue Ridge province, and correlates with the geologic formations listed in Appendix 2.

\section{Karst Aquifers}

Karst aquifers in West Virginia are present within the Valley and Ridge and Appalachian Plateaus Physiographic Provinces. The Valley and Ridge Physiographic Province contains several geologic formations that are dominated by limestone or dolostone; some formations are of a karst nature. Valley and Ridge karst aquifers (fig. 1) are present within the CambrianOrdovician-age Beekmantown, Trenton, Black River, and St. Paul Groups, and the Conococheague and Elbrook Formations; the Silurian-age Tonoloway and Wills Creek Formations; and the Devonian-age Helderberg Group (fig. $3 A$ ). The Cambrian-Ordovician-age aquifers cover substantial areas, but the Silurian- and Devonian-age limestones typically crop out in very thin beds (fig. $3 A$ ). The only significant karst aquifer within the Appalachian Plateaus Physiographic Province is composed of the limestones of the Mississippian-age Greenbrier Group (fig. $3 A$ ). The high maximum transmissivity values for these geologic formations (table 2) indicate that all of these aquifers likely have a substantial karst conduit-flow component accompanying the diffuse-flow component of the fractured-rock matrix within the aquifers. Given the potential for high transmissivity values and rapid infiltration of precipitation, and given that past water-quality studies have shown 


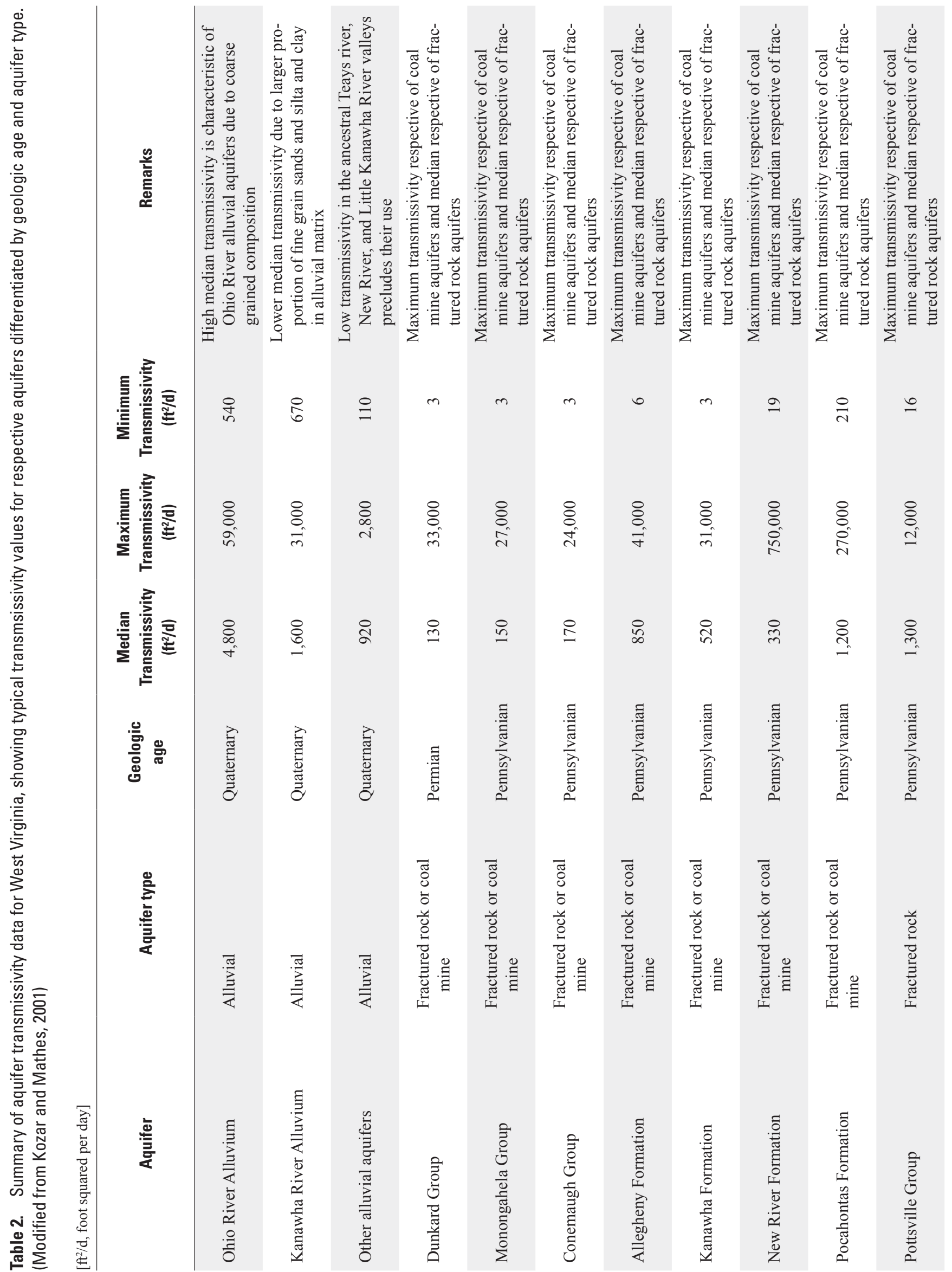




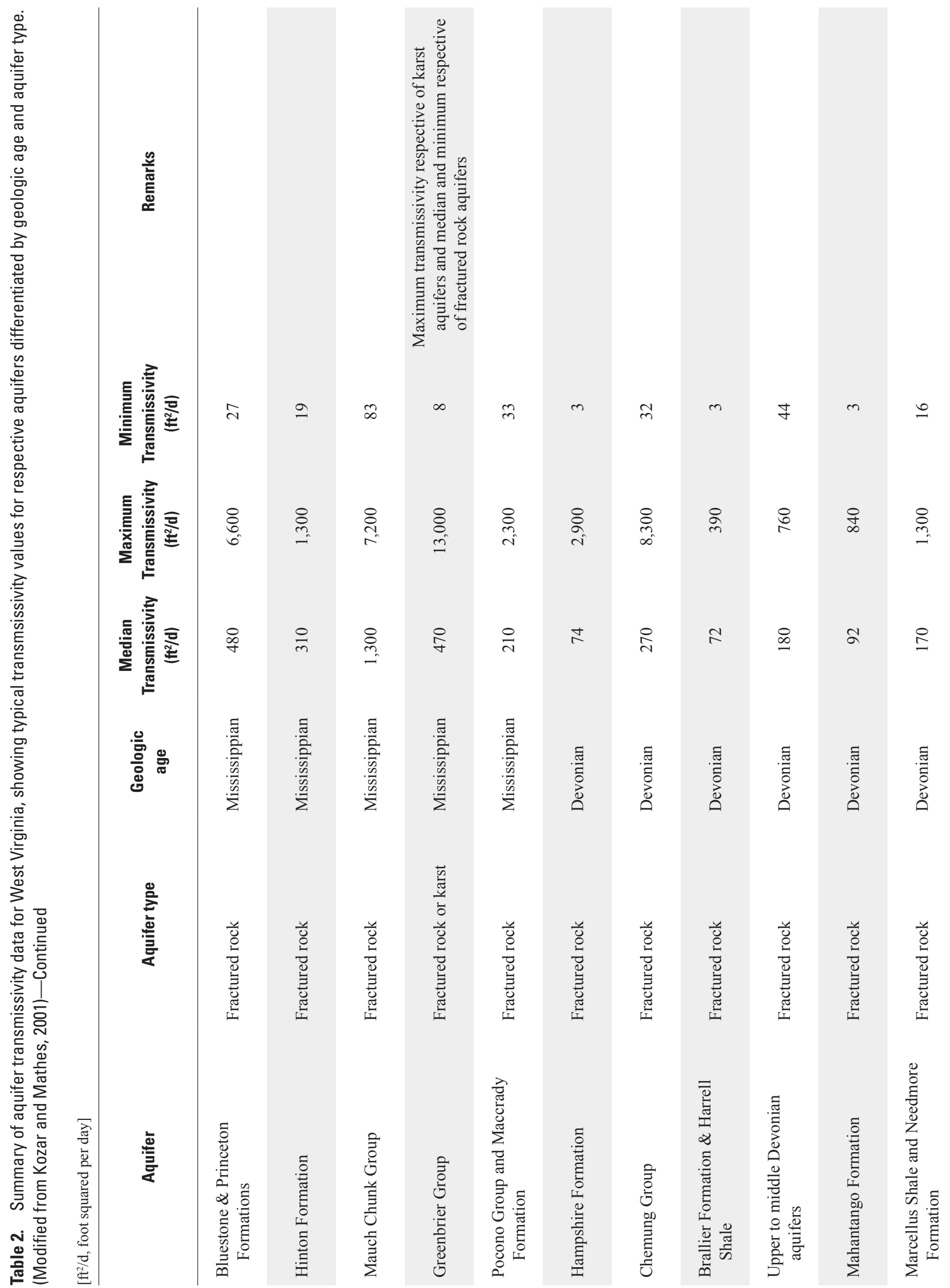




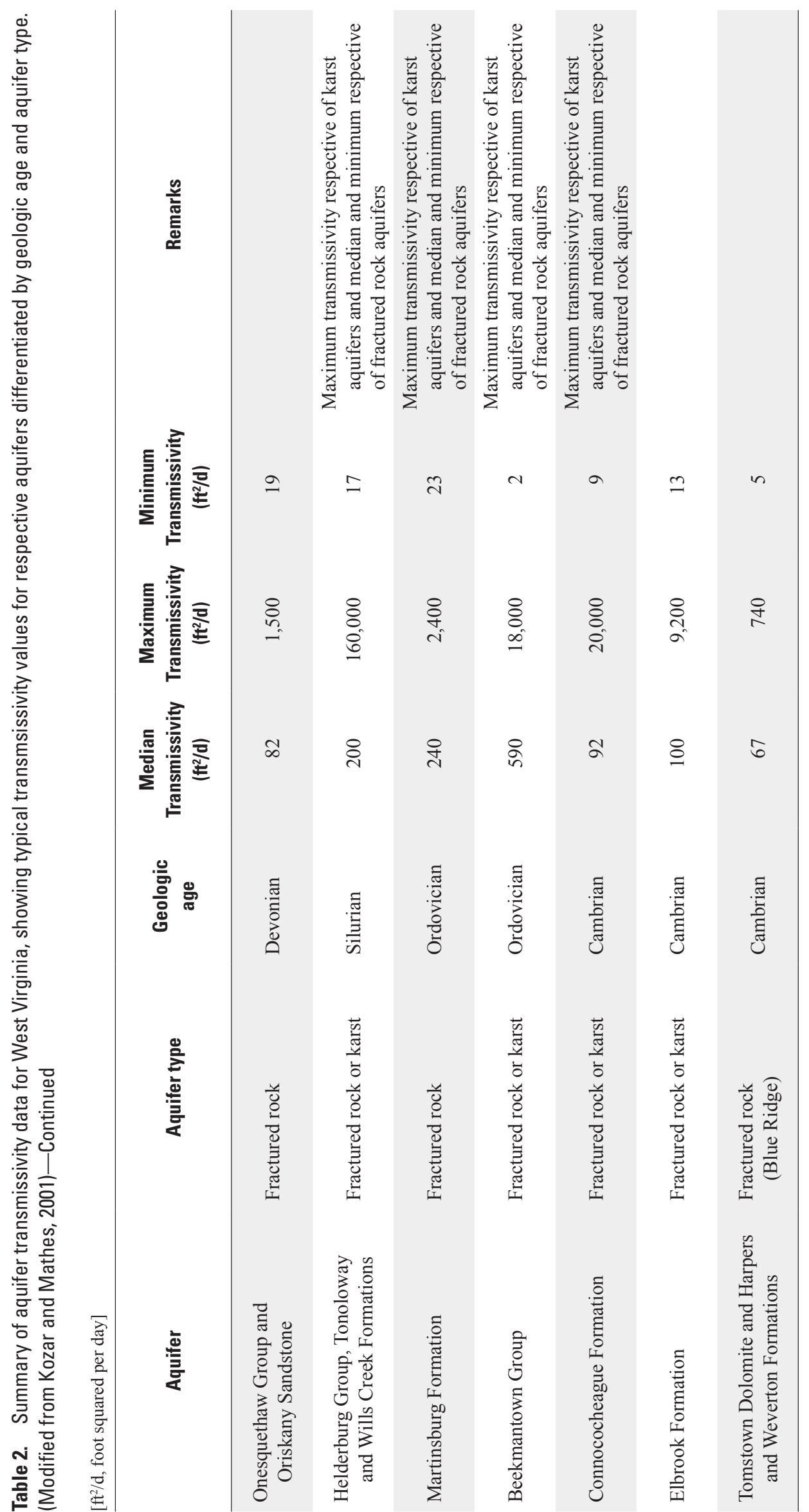


karst aquifers to be easily contaminated by agricultural fertilizers, pesticides, manure, and septic releases, the karst aquifers within the State of West Virginia are the aquifers most intrinsically susceptible to contamination from surface sources.

\section{Fractured Metamorphic and Igneous Rock}

\section{Aquifers}

The igneous and contact metamorphic sedimentary and intrusive rocks of the Blue Ridge, and to a lesser extent the fractured-rock aquifers within the Appalachian Plateaus which have a high proportion of dark shale bedrock, tend to contain a higher percentage of radioactive minerals than elsewhere in the State and, therefore, tend to be sources of radon in groundwater in these areas. Radon concentrations in the Blue Ridge Physiographic Province are the highest documented in the State; three samples had concentrations of radon of 2,300; 3,100; and 8,700 $\mathrm{pCi} / \mathrm{L}$, exceeding the EPA proposed MCL drinking water standard of $300 \mathrm{pCi} / \mathrm{L}$ by 8 to 29 times. The Blue Ridge fractured-rock aquifers have the lowest median transmissivity of all the aquifers within the State (table 2; see values for the Tomstown Dolomite and the Harpers and Weverton Formations). The low median transmissivity is likely associated with smaller capture areas for individual wells, which indicates that fewer contaminant sources might be present in the capture zone than are likely to be present for a well with a larger capture zone.

The thin soils derived from the igneous and metamorphic rocks of the Blue Ridge Physiographic Province, and the steep colluvial slopes typical of the region, provide little capacity to filter contaminants in water recharging the groundwater (Kozar and others, 2001). Concentrations of radon in water from 26 of $30(87 \%)$ wells sampled in North Carolina and Virginia in bedrock similar to that of the Blue Ridge Physiographic Province in West Virginia indicate a high percentage of wells have radon concentrations in excess of the proposed $300-\mathrm{pCi} / \mathrm{L}$ drinking water standard. For 10 of the 30 wells sampled (33\%), the concentrations exceeded the proposed alternate maximum contaminant level of $4,000 \mathrm{pCi} / \mathrm{L}$. Radon, however, is a constituent derived from the radioactive decay of minerals within the bedrock and not a result of surface processes. Kozar and others (2001) found bacterial contamination of groundwater at low levels with only 11 of 29 wells sampled (38\%) testing positive for the presence of total coliform bacteria, and none testing positive for the presence of fecal coliform or E. coli. Owing to the typically low well yields and permeability of the Blue Ridge fractured-rock aquifer, and on the basis of the low potential for bacterial contamination, the crystalline rock aquifers of the Blue Ridge Physiographic Province are considered to have low intrinsic susceptibility and vulnerability to contamination in West Virginia.

\section{Alluvial Aquifers}

Alluvial aquifers in West Virginia (fig. $3 A$ ) are present along the Ohio River, the Kanawha River, and along minor rivers and streams. Alluvial aquifers along the Ohio River are commonly used as a source of water for public supply. Because alluvial sediments along the Ohio River are composed of very coarse-grained glacial outwash deposits overlain by finer grained fluvial deposits (Simard, 1989), Ohio River alluvial aquifers tend to have very high median and maximum aquifer transmissivity (table 2). Wells completed in the Ohio River alluvial aquifers have the capacity to derive significant recharge from the Ohio River, given the high withdrawal rates and proximity to the river (Kozar and McCoy, 2004). Ranneystyle collector wells at Parkersburg, West Virginia, have radial arms that extend beneath the river and are designed to induce infiltration of water from the river. Using a groundwaterflow model developed for the Parkersburg area, Kozar and McCoy (2004) estimated that on average 75 percent of the water withdrawn by the Parkersburg municipal water plant is derived from induced recharge from the Ohio River, and only 25 percent is derived from alluvial aquifer water recharged by precipitation. Alluvial aquifers along minor tributary streams are not frequently tapped as a source of water for public supply because of the low permeability and minimal thickness of alluvial sediments. The Kanawha River alluvium is not a common source of water for public supply, but historically it has been used as a source of water for industry. Alluvial sediments bordering the Kanawha River are of fluvial origin and are not as coarse grained as the sediments composing Ohio River alluvium (Doll and others, 1960; Wilmoth, 1966). Even though the transmissivity of alluvial aquifers bordering the Ohio River, and to a lesser extent the Kanawha River, is high (table 2), wells tapping the alluvial sediments typically do not contain indicator bacteria such as fecal coliform and total coliform because flow of water through the sediments tends to filter out bacteria (Jeffords, 1945). However, dissolved chemical contaminants, such as VOCs and nitrate, are typically not removed by sediments (Chambers and others, 2012). Given the potential for alluvial aquifers to receive significant recharge from adjacent rivers, and given the capacity for the alluvial sediments to act as microbial filters, alluvial aquifers have a low intrinsic susceptibility to microbial contaminants 
but a high intrinsic susceptibility to VOCs, nitrate, or other chemicals released or spilled at or near the surface.

Given the potential for large amounts of induced recharge from rivers, and the young groundwater ages of alluvial aquifer waters (discussed in more detail in the "Chlorofluorocarbons" section of this report), alluvial aquifers in West Virginia are considered the second most intrinsically susceptible aquifers in the State of West Virginia. Note, however, that even though alluvial aquifers are susceptible to contamination, no alluvial aquifers in West Virginia have been identified as GWUDI of surface water, as per guidance from the EPA (2004, 2008 a and b, $2010 \mathrm{a}$ and b), owing to a lack of indicator bacteria and microscopic particulates in raw process water. Therefore, although the intrinsic susceptibility may be high, vulnerability to bacterial contamination may be low.

\section{Coal-Mine Aquifers}

A small sub-category of Appalachian Plateaus fracturedrock aquifers are abandoned underground coal mines located at elevations either below local stream drainage (fully or partially flooded mines) or above local stream drainage (partially flooded adits or free flowing discharge from adits) that are commonly used as a source of water for public supply (fig. 4). Abandoned-coal-mine aquifers have much higher transmissivity (Shultz, 1988) and potential for water storage (McColloch and others, 2012) than unmined rocks of similar composition (fig. 5). The hydrologic effects of coal mining include several important alterations to the movement of water and the magnitude and timing of flow (Callaghan and others, 1998). In underground coal mines, water flows down dip along the

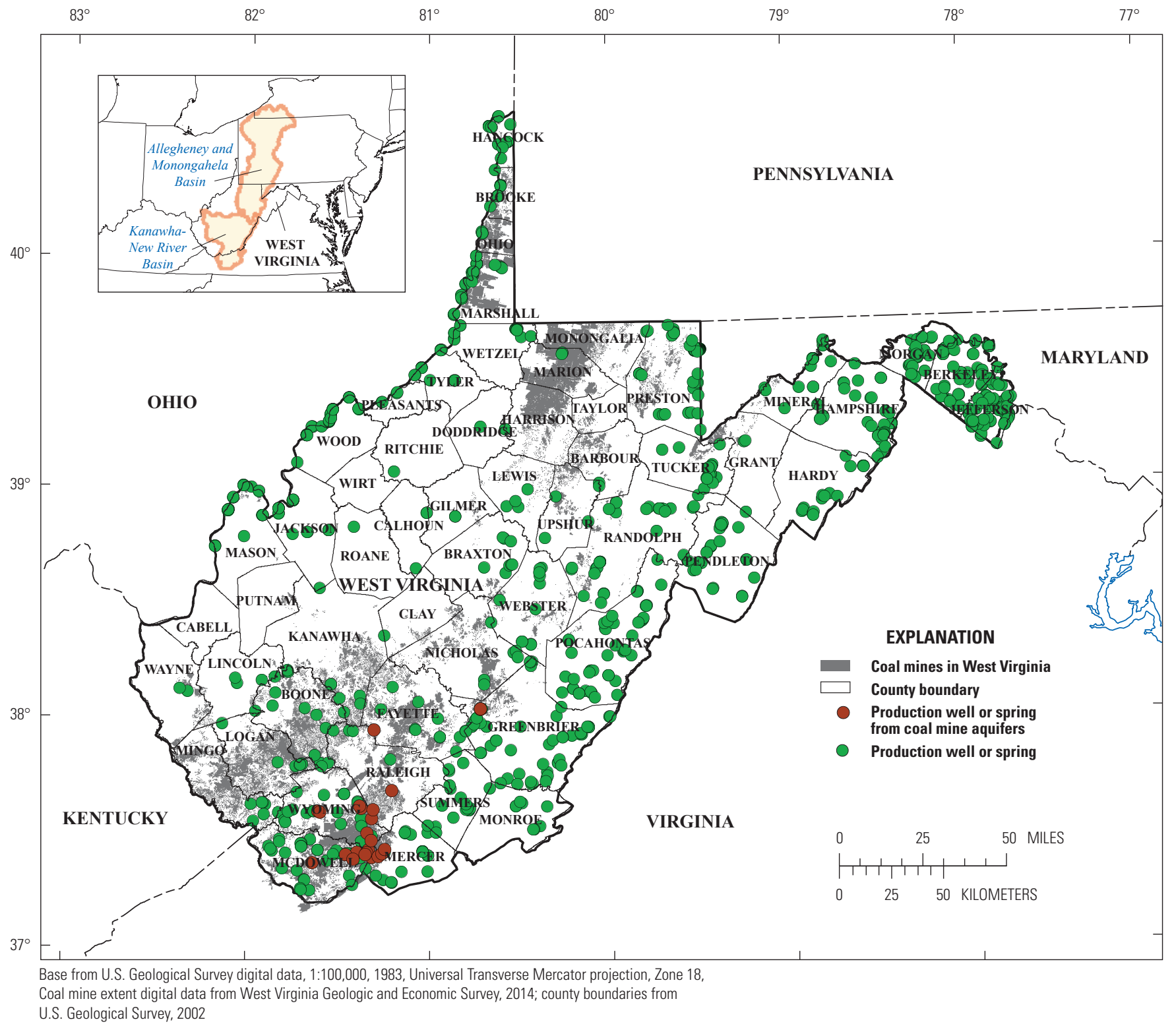

Figure 4. Distribution of current and abandoned underground coal mines in West Virginia and locations of production springs or wells that tap these underground mines, with production springs and wells that tap other aquifers. 


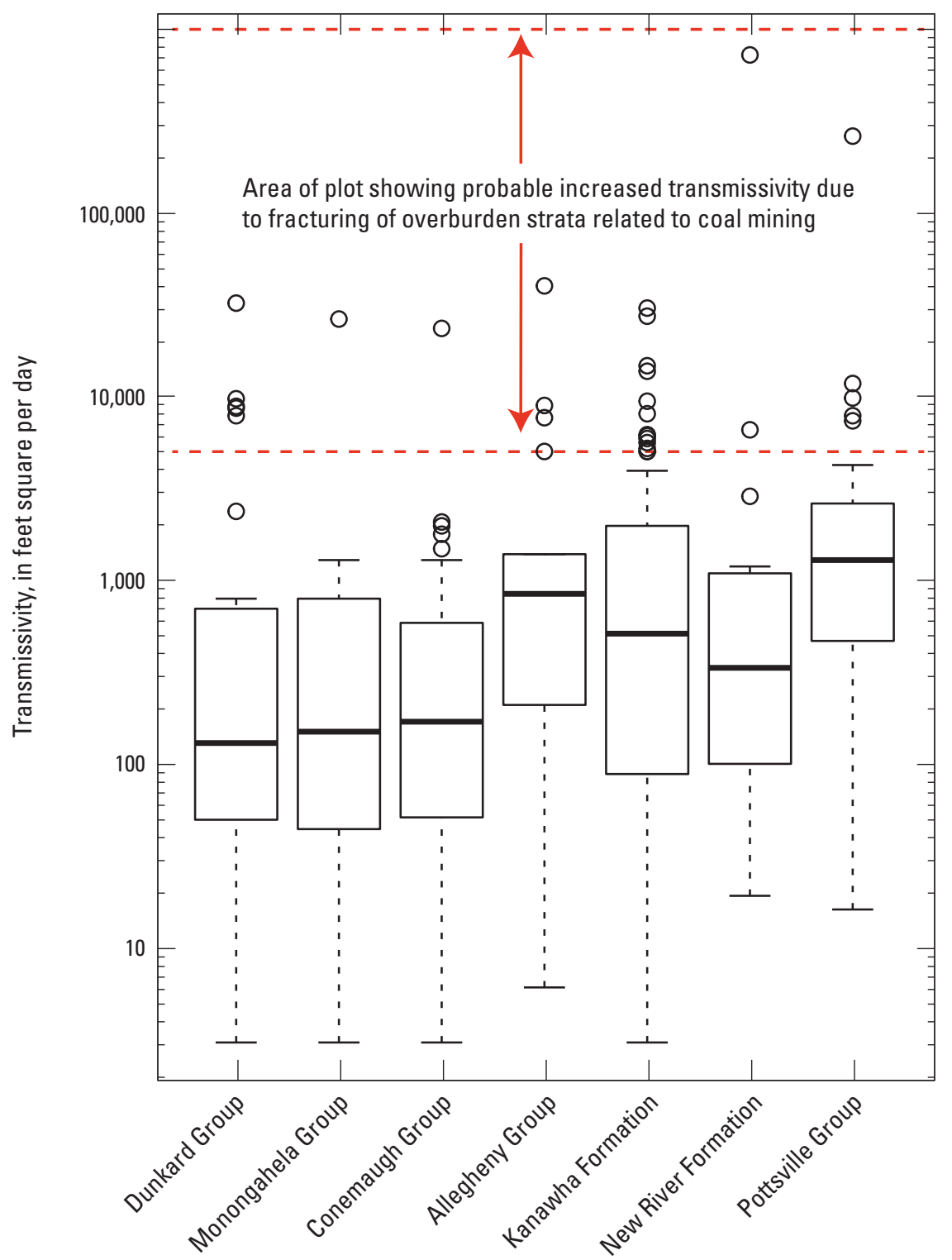

EXPLANATION

Transmissivity

O Outlier

$\rightarrow \quad 90$ th percentile

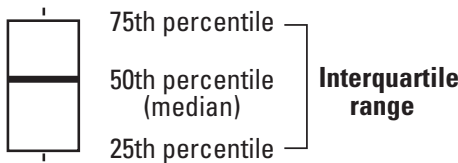

- 10th percentile

Figure 5. Distribution of transmissivity for coal-bearing bedrock groups and formations in West Virginia. 
mine floor, even in areas where the dip is slight. If the mined seam is above grade or higher than the elevation of the local streambed, water can be transferred from the up dip side of the mountain to the down dip side (Kozar and others, 2012). If the mined seam is below grade or if it dips from above grade on its uphill side to below grade on the down dip side, water collects in a pool in the void space in a mine (McColloch and others, 2012). Where mining is active, the water is pumped to the surface and discharged. Even after mining ends, water from mine pools may still reach land surface through openings if hydraulic head is sufficient. One consequence of underground coal mining is the disturbance of the natural flow system, which can induce changes in natural patterns of groundwater flow resulting from interconnected mine voids. Voids can extend beneath and beyond local topographic divides, which allows interbasin transfer of groundwater in these aquifers (Kozar and others, 2012). Alternatively, mine openings or fractures in collapsed overburden layers can intersect land surface, allowing the loss of water from overlying streams to underlying coal-mine aquifers (Ferrell, 1992). The maximum transmissivity values for coal-mine aquifers in table 2 are indicative of abandoned-underground-coal-mine aquifers with associated fracturing of overburden rock strata.

Long-wall coal mines are a specific type of underground coal mine where a shear passes along the face of the coal seam, removing an entire length of coal sometimes several hundreds of feet in width. The remaining overburden strata collapse to fill the void left behind by the shear as it extracts the coal. Where long-wall underground coal-mine passages cross beneath tributary streams or rivers, there is increased potential for fracturing of overburden strata compared to fracturing from more conventional mining methods; the fractures can provide a pathway for stream water to enter abandonedcoal-mine aquifers (Shultz, 1988). When the overlying stream water contains a high concentration of bacteria, the underlying abandoned-coal-mine aquifer has the potential to be easily contaminated with bacteria and other potentially pathogenic organisms if the subsidence from the underlying coal mines extends to the surface and intersects the stream. On the basis of previous studies (Shultz, 1988; Hobba, 1981b, 1987) and maximum transmissivity data for Appalachian Plateaus fractured-rock aquifers (fig. 5), abandoned-underground-coal-mine aquifers may have a moderate (conventional mining methods) to potentially high (long-wall mining) intrinsic susceptibility to contamination from surface sources. Vulnerability, however, is based on the presence or absence of potential contaminants in the area overlying the mine or in a stream that crosses over the mine and, therefore, would need to be assessed on a siteby-site basis.

\section{Fractured Sedimentary Rock Aquifers}

The most areally extensive physiographic province in West Virginia is the Appalachian Plateaus (fig. 1). The Appalachian Plateaus are characterized by relatively flat-lying sedimentary rocks composed mostly of sandstone, shale, mudstone, siltstone, and coal of Mississippian through Permian age. The fractured rocks of the Appalachian Plateaus in West Virginia are part of a regionally extensive aquifer system of small local-scale, fractured-rock aquifers. Groundwater flow is usually local with recharge to the aquifers occurring predominantly within closed watersheds. Groundwater flow is dominated by fracture flow in stress-relief fractures in hillsides and valleys and upward arching bedding in valleys (Wyrick and Borchers, 1981), and is separated by topographic divides. The median, maximum, and minimum transmissivity values for fractured-rock aquifers within the Appalachian Plateaus Physiographic Province are highly variable (table 2), owing to coal mining which occurs in certain coal-bearing strata including the Dunkard Group, Monongahela Group, Conemaugh Group, Allegheny Formation, Kanawha Formation, New River Formation, Pocahontas Formation, and the Pottsville Group (table 2). In table 2, the median and minimum transmissivity values listed are more characteristic of fractured-rock aquifers than abandoned-coal-mine aquifers, whereas the maximum transmissivity values are more characteristic of abandonedcoal-mine aquifers. A study of the hydraulic characteristics of unmined coal seams in Pennsylvanian-age rocks just across the state line in Virginia indicates that even unmined coal seams tend to have higher transmissivity than associated sandstone and shale bedrock in coreholes (Harlow and LeCain, 1993). Non coal-bearing fractured-rock aquifers within the Appalachian Plateaus Physiographic Province include the Maccrady Formation, Pocono and Greenbrier Groups, and the Bluefield, Hinton, Bluestone, and Princeton Formations (grouped as the Mauch Chunk in areas of thin stratigraphic occurrence). Within the Appalachian Plateaus, fractured-rock aquifers in the northern part of the State have a higher proportion of shale bedrock than the fractured-rock aquifers in the southern part of the State, which have a larger proportion of sandstone. As such, the fractured-rock aquifers in the northern part of the state have slightly lower median transmissivity values than the fractured-rock aquifers in the southern part of the State (table 2 and figs. 4 and 5).

Fractured sedimentary-rock aquifers also occur in the Valley and Ridge Physiographic Province (fig. 1), and there is some overlap between Appalachian Plateaus and Valley and Ridge aquifers with respect to Mississippian-age and Devonian-age fractured-rock aquifers. However, Valley and Ridge aquifers have a larger proportion of shale bedrock and, therefore, have a much lower median transmissivity than Mississippian- or Pennsylvanian-age fractured-rock aquifers, which have a larger proportion of sandstone (table 2). The Valley and Ridge Physiographic Province contains geologic formations that are dominated by limestones, some of which are of a karst nature. Higher yielding wells, such as are typical of municipal wells, are usually more susceptible to contamination because they tend to capture water from a larger area than loweryielding wells, which typically are wells drilled for residential use. Fractured-rock aquifers in Morgan County are similar to the fractured-rock aquifers elsewhere in the State; iron, 
manganese, and radon are common contaminants. In Morgan County, a much lower percentage of fractured-rock wells tested positive for fecal coliform or E. coli bacteria as a result of the more stringent casing, grouting, and drilling requirements established for Morgan County. On the basis of the studies of fractured-rock aquifers within Appalachian Plateaus and Valley and Ridge Physiographic Provinces, these aquifers are considered to be the aquifers least intrinsically susceptible to anthropogenic contamination within West Virginia and have a very low intrinsic susceptibility on the basis of hydrogeologic factors. The major constituents of concern are iron, manganese, and radon, which are naturally occurring in bedrock and are not derived from shallow surface processes, but are rather a function of hydrogeologic terrain and redox conditions within the aquifer. Fecal coliform bacteria and E. coli were found to be prevalent in wells that were completed prior to 1997 when statewide regulation of residential wells and requirements for grouting wells were established. Wells of newer construction that are properly grouted are much less vulnerable to fecal coliform bacteria or surface contamination than are older wells, especially those that were not grouted or were poorly grouted (Boughton and McCoy, 2006).

\section{Groundwater Hydraulics as a Factor for Assessing Aquifer Susceptibility}

Groundwater hydraulics can also play an important role in understanding the intrinsic susceptibility and potential vulnerability of groundwater supplies to contamination. Where sufficient data are available, such data may be used to aid in SWIGS determinations. A full discussion of groundwater hydraulics, derivation of the groundwater-flow equation, and discussion of the hydrologic cycle is beyond the scope of this report. However, a brief summary of Darcy's Law and other concepts that relate to groundwater and surface-water interactions are presented here to provide examples of how groundwater hydraulic data can be used to aid in potential determination of SWIGS.

Groundwater flow through porous media is described by the partial differential equation for groundwater flow. An algebraic form of the groundwater-flow equation is expressed by Darcy's law (Lohman, 1972):

$$
\mathrm{q}=\mathrm{Q} / \mathrm{A}=-\mathrm{K} \delta \mathrm{h} / \delta 1 \quad\left[\mathrm{LT}^{-1}\right]
$$

where

$$
\begin{aligned}
& \text { Q is volumetric discharge of groundwater } \\
& \text { within an aquifer }\left[\mathrm{L}^{3} / \mathrm{T}\right] \text {, } \\
& \mathrm{K} \text { is aquifer hydraulic conductivity [L/T], } \\
& \delta \mathrm{h} / \delta \mathrm{l} \text { is the change in head over distance of the } \\
& \text { hydraulic gradient [unitless], and } \\
& \text { A is the cross-sectional area of the aquifer [ } \left.\mathrm{L}^{2}\right] \\
& \text { (Lohman, 1972). }
\end{aligned}
$$

Darcy's Law is more commonly expressed as

$$
\mathrm{Q}=-\mathrm{KA} \delta \mathrm{h} / \delta 1 \quad \text { or } \quad \mathrm{Q}=-\mathrm{KiA}
$$

where i represents the hydraulic gradient $\mathrm{dh} / \mathrm{dl}$ term. For average velocity $(v)$, the porosity of the aquifer material $(\theta)$ must be known. Equation 2 can then be arranged in the form

$$
\mathrm{Q}=\mathrm{vA} \theta=-\mathrm{KA} \delta \mathrm{h} / \delta 1
$$

Rewriting equation to solve for average velocity (v), we obtain

$$
v=-\mathrm{K} \delta \mathrm{h} / \delta 1 / \theta \quad \text { or } \quad v=-\mathrm{Ki} / \theta\left[\mathrm{LT}^{-1}\right] .
$$

Assuming aquifer vulnerability is related to groundwater velocity, equation 4 presents measurable variables, $\mathrm{K}$ and $\mathrm{i}$, which along with estimates of porosity permit an assessment of groundwater velocity, which can be used to help assess the intrinsic susceptibility and potential vulnerability of groundwater to contamination.

Groundwater-flow models such as MODFLOW 2000 (Harbaugh and others, 2000), which use finite difference methods, are used to approximate the differential equation describing groundwater flow (McDonald and Harbaugh, 1988). One such approach is the finite difference method, wherein the continuous system described by the partial differential equation for groundwater flow is replaced by a finite set of discrete points in space and time, and the partial derivatives are replaced by terms calculated from the differences in head at these points.

Groundwater-flow models contain numerous cells within a single or multi-layered grid and may provide significant insight into groundwater-flow processes within a region. Such models can be very simplistic and contain only a few cells, such as simple models to estimate the zone of contribution to a single pumping well, or can assess the interaction of a single pumped well with a boundary condition, such as a no-flow boundary, or an infinite source of recharge, such as a nearby stream or lake. Other models can be extremely complex, containing hundreds of thousands of cells, and provide hydraulic head and flow estimates over vast multi-state areas for multiple aquifers and confining units. Several USGS investigations completed for West Virginia used various versions of MODFLOW to produce numerical groundwater-flow models to better understand complex groundwater and surface-water interactions within alluvial aquifers (Kozar and McCoy, 2004), karst aquifers (Kozar and others, 2007a; Kozar and Weary, 2009), and above-drainage coal-mine aquifers in West Virginia (Kozar and others, 2012).

Streams can be either gaining or losing, depending on the direction of the hydraulic gradient between a given stream and an adjacent aquifer (fig. 6). In some cases, such as in karst areas of Jefferson and Berkeley Counties, West Virginia, streams can alternate between gaining and losing reaches (Evaldi and Paybins, 2006A, B) naturally over the course of a stream. In the eastern United States, most of the natural streams are gaining and derive most of their water from 
$A$

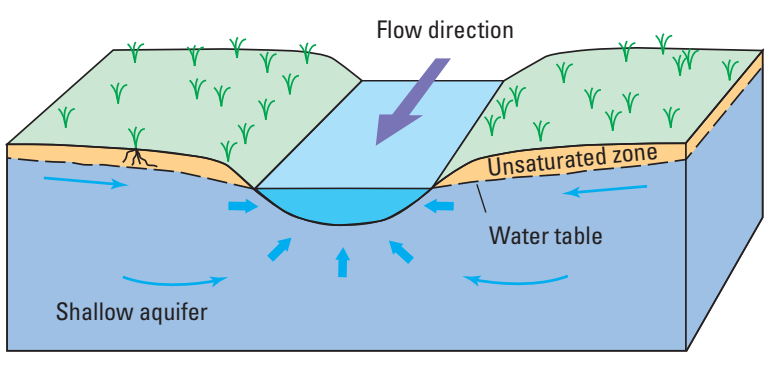

$A$

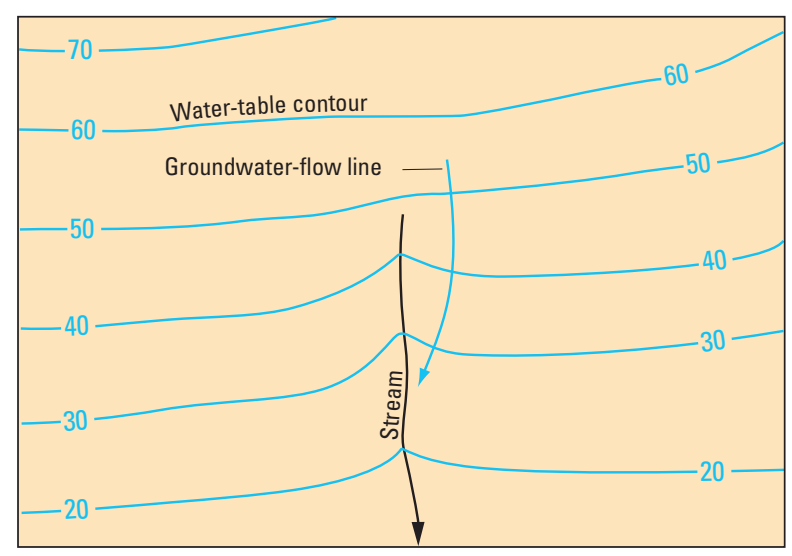

$B$

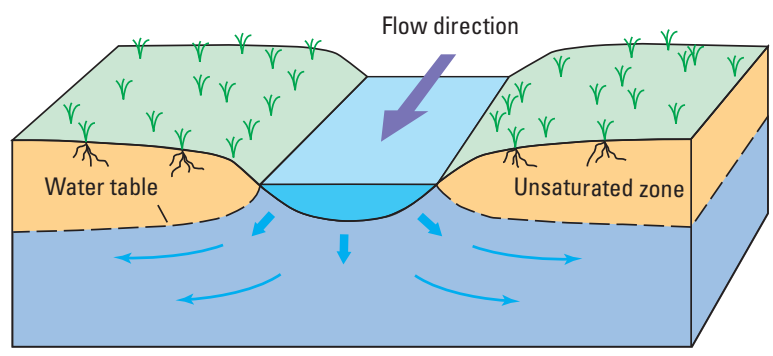

$B$

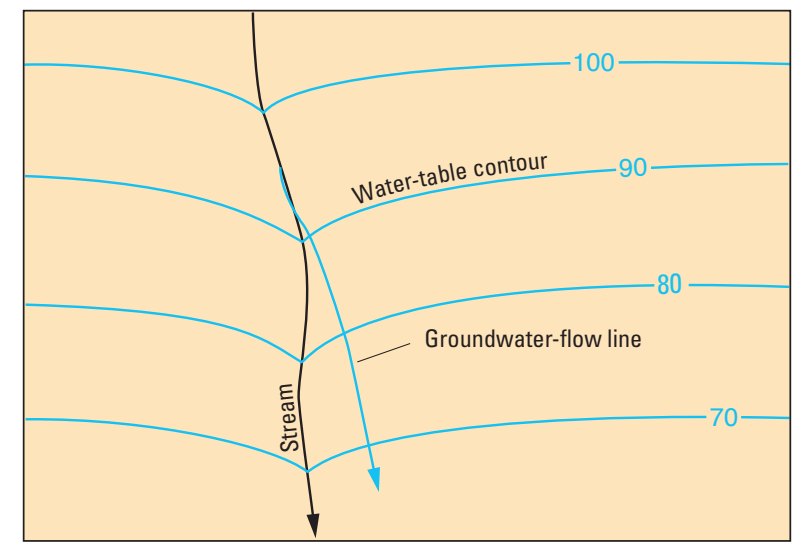

Figure 6. Water-level contours for $A$, gaining and $B$, losing streams. (Modified from Winter and others, 1998)

base-flow groundwater discharge to streams (Nelms and others, 2015). Groundwater withdrawals can reverse the normal hydraulic gradient towards a stream, causing streamflow to flow from the stream back into an aquifer (Goode and others, 2014). Hydraulic gradients may be determined for certain areas by measuring water levels in a number of wells in the vicinity of a production well, well field, or spring.

In the simplest of cases, if hydraulic gradients show that water-level elevations in monitored wells are higher than the elevation of a nearby stream or surface-water body, then the aquifer may not be deriving a significant amount (and potentially little) of recharge from the nearby stream, lake, or pond (fig $7 A$ ). Groundwater withdrawals can alter natural groundwater-flow patterns, and a well situated near a stream may derive recharge from the aquifer at certain withdrawal rates and still not derive recharge from the nearby surface-water body (fig. 7B). If pumping rates are increased to a rate higher than that which may be supplied by the aquifer, then it is possible that recharge will be induced from the river or nearby surface-water body (fig. 7C). The scenarios represented in figure $7 B$ and $7 C$ occur for the alluvial aquifer in the Parkersburg and Vienna areas in Wood County, West Virginia (Kozar and McCoy, 2004). Kozar and McCoy (2004) found that 6 wells within the Parkersburg area, completed in alluvial deposits bordering the Ohio River, derive at least some portion of recharge directly from the Ohio River (fig. 8), whereas only 2 of 6 wells completed in the alluvial aquifer in the Vienna area derive recharge from the Ohio River (fig. 8). Figure 8 shows 5-year time of travel estimates derived using the MODPATH (Winston, 1999) particle tracking software for wells in the Parkersburg and Vienna areas. Such particle tracking simulations are an effective tool for estimating recharge areas to wells and can be used as part of the SWIGS determination process where such simulations are available.

River stage can also affect recharge to aquifers. Under base-flow conditions when most of the water within a stream is derived from groundwater discharge to the stream, hydraulic gradients are commonly towards the stream as depicted in figures $7 A$ and $9 A$. However, when river stage rises as occurs during and after heavy precipitation events, stream water can cause a reversal of the normal hydraulic gradient and provide recharge to the aquifer (fig. $9 B$ ), or as a result of flooding, river stages can rise to levels above the elevation of the adjacent aquifer (fig. 9C). Such flooding of alluvial aquifers can be especially problematic and, if wells are not constructed to prevent entry of stream water into the well, can result in bacterial 
$A$

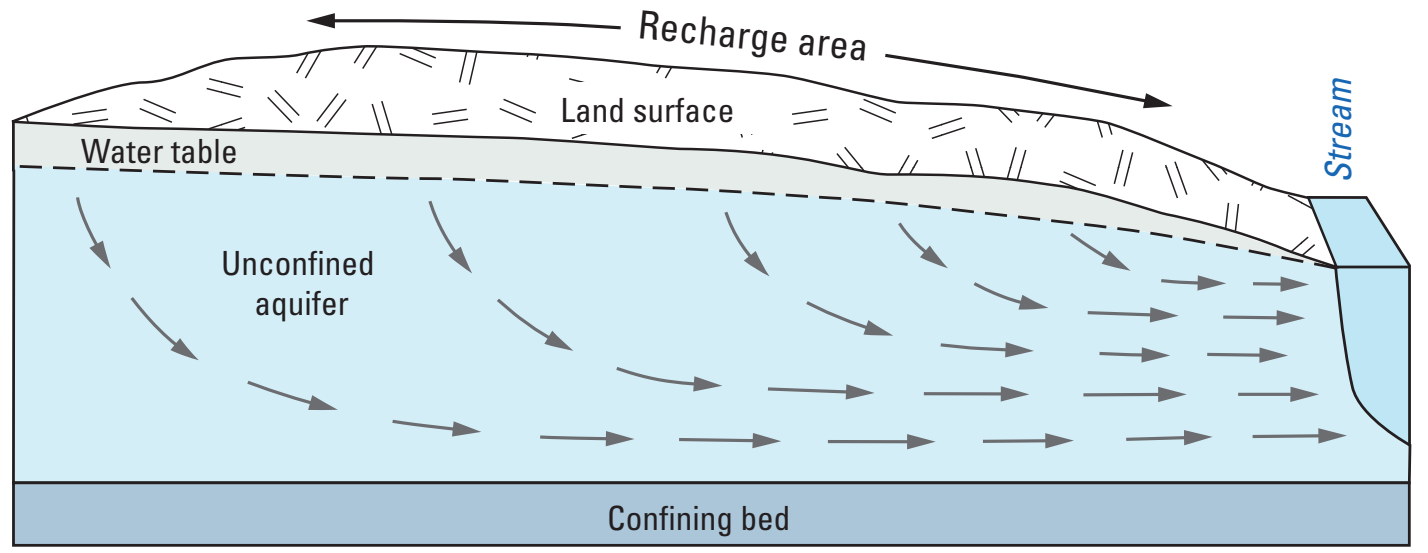

$B$

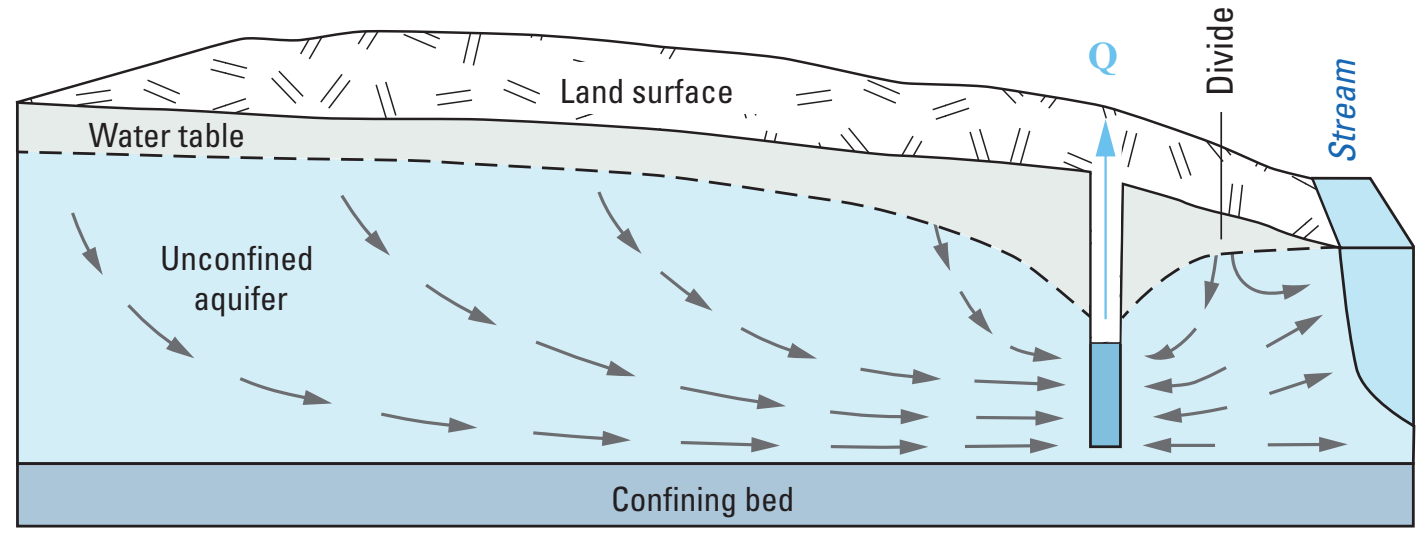

C

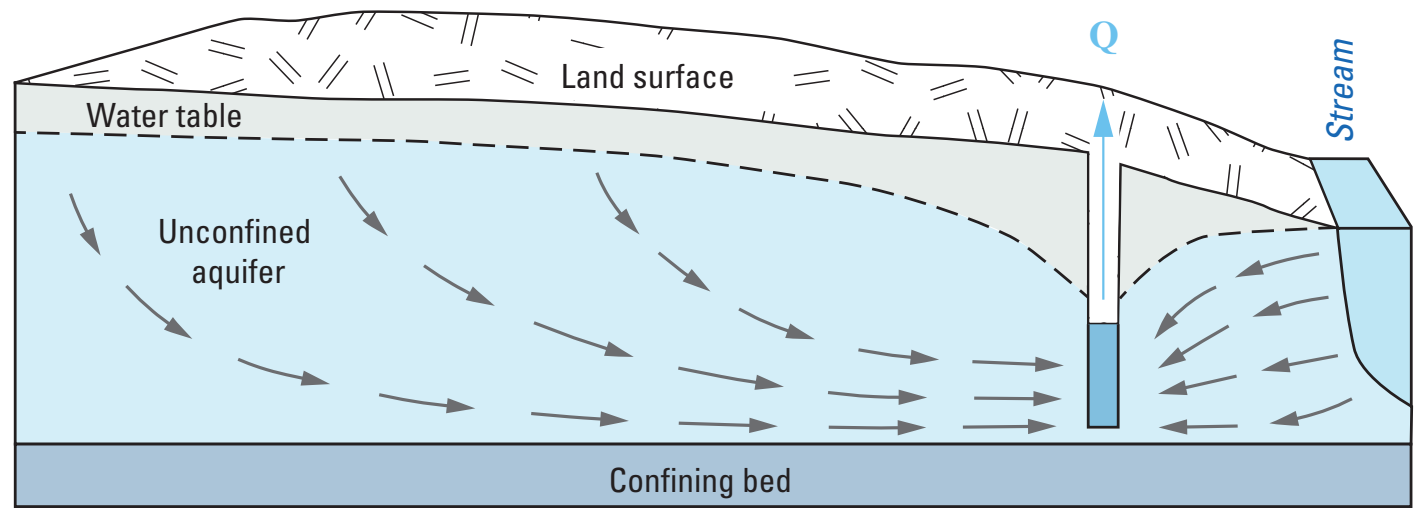

Figure 7. Hydraulic gradient $A$, towards a stream, $B$, towards a pumping well deriving recharge solely from the aquifer, and $C$, a pumping well that is deriving recharge both from the aquifer and from a nearby stream. (Modified from Winter and others, 1998) 


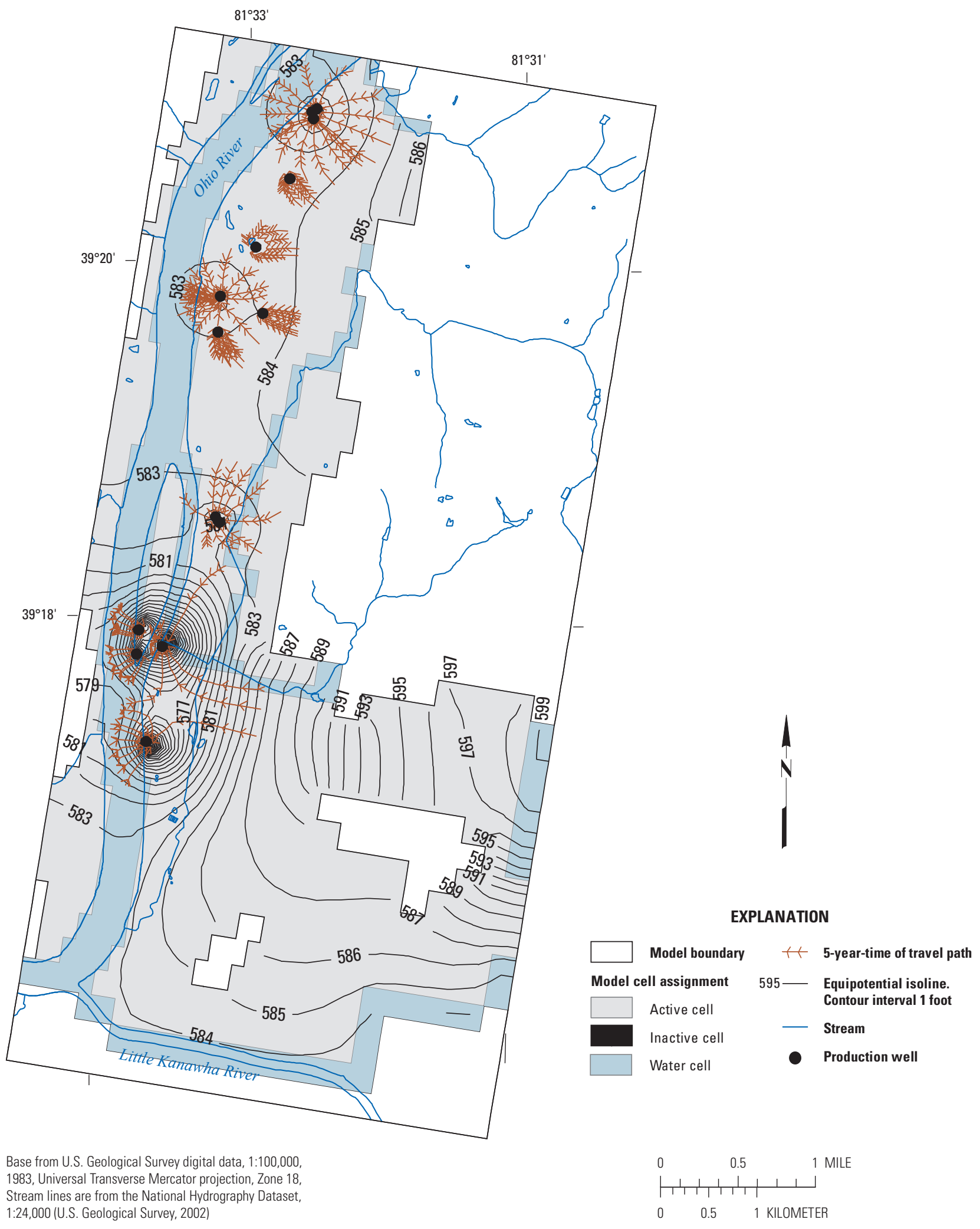

Figure 8. Calibrated heads and 5-year time-of-travel paths to wells completed in alluvial deposits bordering the Ohio River in the Parkersburg and Vienna areas, Wood County, West Virginia. (Kozar and McCoy, 2004) 

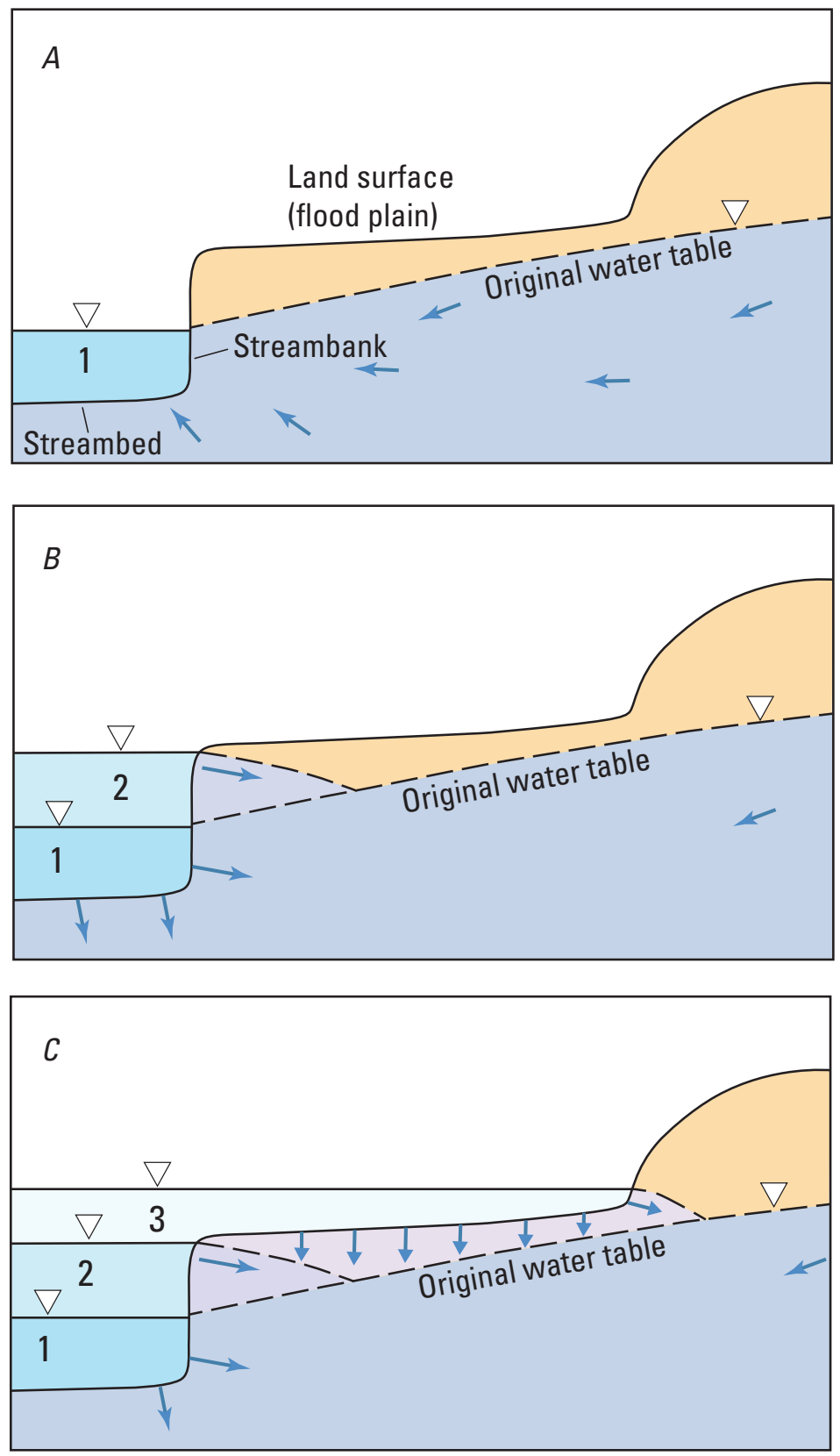

EXPLANATION

$\begin{array}{llll}\nabla & \nabla & \end{array} \quad$ Sequential stream stages

$\longrightarrow$ Approximate direction of groundwater flow or recharge through the unsaturated zone

Figure 9. Hydraulic gradient $A$, towards a stream, $B$, induced recharge to an aquifer as a result of rising stream stage, and $C$, over topping of an aquifer by flood waters. (Winter and others, 1998) 
contamination of the well. As a result it is important to evaluate whether production wells are situated in a flood plain and assure that wells situated in a flood plain are constructed so as to prevent entry of surface water in the event of a flood that over tops the wells. Mapping of flood plains for production wells in West Virginia was conducted as part of this study, and the data were provided to the WVDHHR in support of their SWIGS determination process.

In the absence of complex numerical groundwater-flow models, if water-level data are available or can be obtained, mapping of groundwater levels by producing a potentiometricsurface map is a good way to assess the potential for groundwater and surface-water interactions (fig. 10). Direction of groundwater flow can often be inferred from potentiometricsurface maps, which help to assess the potential for migration of contaminants from known sources towards a production well. Monitoring of water-temperature and water-quality fluctuations can provide additional evidence to support determination of a connection or lack thereof between a production well and a nearby surface-water body.

Hydraulic gradients based on water levels in a few wells may not always afford a clear indication of the potential for a hydraulic gradient towards a pumped well or spring in complex hydrogeologic terrains such as fractured-rock aquifers. In fractured-rock terrains, such as are common in West Virginia, several fractures may yield water to a well, but only one or more of the fractures may actually be in hydraulic connection with a nearby surface-water body. In such a case, there may be a connection between the well and a nearby surface-water body, but the composite head for all the water-producing fractures does not indicate a hydraulic gradient to the pumped well or spring. In such cases, discrete-zone packer testing can be conducted on the pumped wells to establish the head relations between all the water-producing fractures in the well. Borehole and surface geophysics may be required to map the fracture distribution and interconnectedness or lack thereof of a fracture to a nearby surface-water body. Regardless, measurement of water levels and creation of potentiometricsurface maps are a good way, in most cases, to assess potential flow directions towards a well or spring and can be employed as part of the SWIGS determination process.

Hydrograph separation and analysis programs, such as PART (Rutledge, 1998) and HYSEP (Sloto and Crouse, 1996), may be used to separate streamflow into surface-runoff and base-flow components and to estimate groundwater recharge. Estimates of groundwater recharge for West Virginia, using hydrograph separation and analysis methods, range from a mean of only 8.4 inches per year (in/yr) for the Little Kanawha River watershed to a mean of as much as $24.6 \mathrm{in} / \mathrm{yr}$ for the eastern part of the Kanawha River watershed (Kozar and Mathes, 2001). Base-flow discharge to streams accounts for all but about $2 \mathrm{in} / \mathrm{yr}$ of the mean estimated recharge. Results of similar hydrograph separation methods for streams in mined and unmined areas of southern West Virginia in McDowell County show that base flow composes 47.2 percent of streamflow in relatively unmined areas to as much as 98.5 percent of streamflow in Johns Knob Branch, a heavily mined area with significant interbasin transfer of groundwater via discharge from mine adits (Kozar and others, 2012). Median base flow, based on hydrograph separation, for streams in McDowell County was 64.1 percent of streamflow. Because coal mining can fracture overburden rock, it can create man-made hydrologic flow systems similar to that of karst limestone and dolostone hydrogeologic terrains.

In karst areas of West Virginia similar estimates of high base-flow percentage of streamflow were documented; 93 percent of streamflow in the Hopewell Run watershed was attributed to base-flow discharge to streams. With such high percentages of groundwater discharge to streams, a relatively minor amount of surface runoff to streams after storms, and the ease with which precipitation infiltrates the aquifer in karst areas (Kozar and others, 2007a and b), during the SWIGS determination process, it is important to be cognizant of potential non-point source activities, such as agriculture in karst areas, as much as and possibly more than potential capture of water from adjacent streams, lakes, rivers, or ponds.

Interbasin transfer, as assessed in the Elkhorn Creek study in McDowell County (Kozar and others, 2012), is common in many mined areas of West Virginia and presents unique challenges for assessing potential SWIGS because interbasin transfer can occur as groundwater travels down dip along abandoned mine workings beneath topographic divides (fig. 11). Note that the groundwater-flow lines in figure 11 are in the opposite direction from some of the streams in the eastern part of the model domain, which illustrates the down dip interbasin transfer of groundwater along the base of abandoned mine workings in the Pocahontas No. 3 coal seam. As such, the potential for interbasin transfer needs to be accounted for as part of the SWIGS determination process for wells in mined areas where interbasin transfer is suspected.

However, without developing sometimes costly and time-consuming numerical groundwater-flow models, simple graphical examination of mine maps and structure contours for coal seams that can be done easily with Arc-GIS can be used to accurately estimate the potential, or lack thereof, for interbasin transfer and accurately estimate recharge areas for abandoned coal-mine aquifers. Mine maps and structure contours for most mined areas and coal seams within West Virginia are available from the WVGES. As with karst hydrogeologic terrains, non-point sources of contamination may be as much, or possibly more, of a concern for mined areas than for unmined areas in fractured rock.

Numerical groundwater-flow models developed using MODFLOW for the Hopewell Run and Opequon Creek watersheds illustrate the utility of numerical models for assessing recharge areas to production wells and for assessing potential interaction between groundwater and nearby surface-water bodies in karst areas of West Virginia. Figure 12 was developed as part of a MODFLOW simulation of groundwater flow in the area around Leetown, in Jefferson County, West Virginia (Kozar and others, 2007a); it illustrates the simulated drawdown around pumped wells in the Leetown area using 


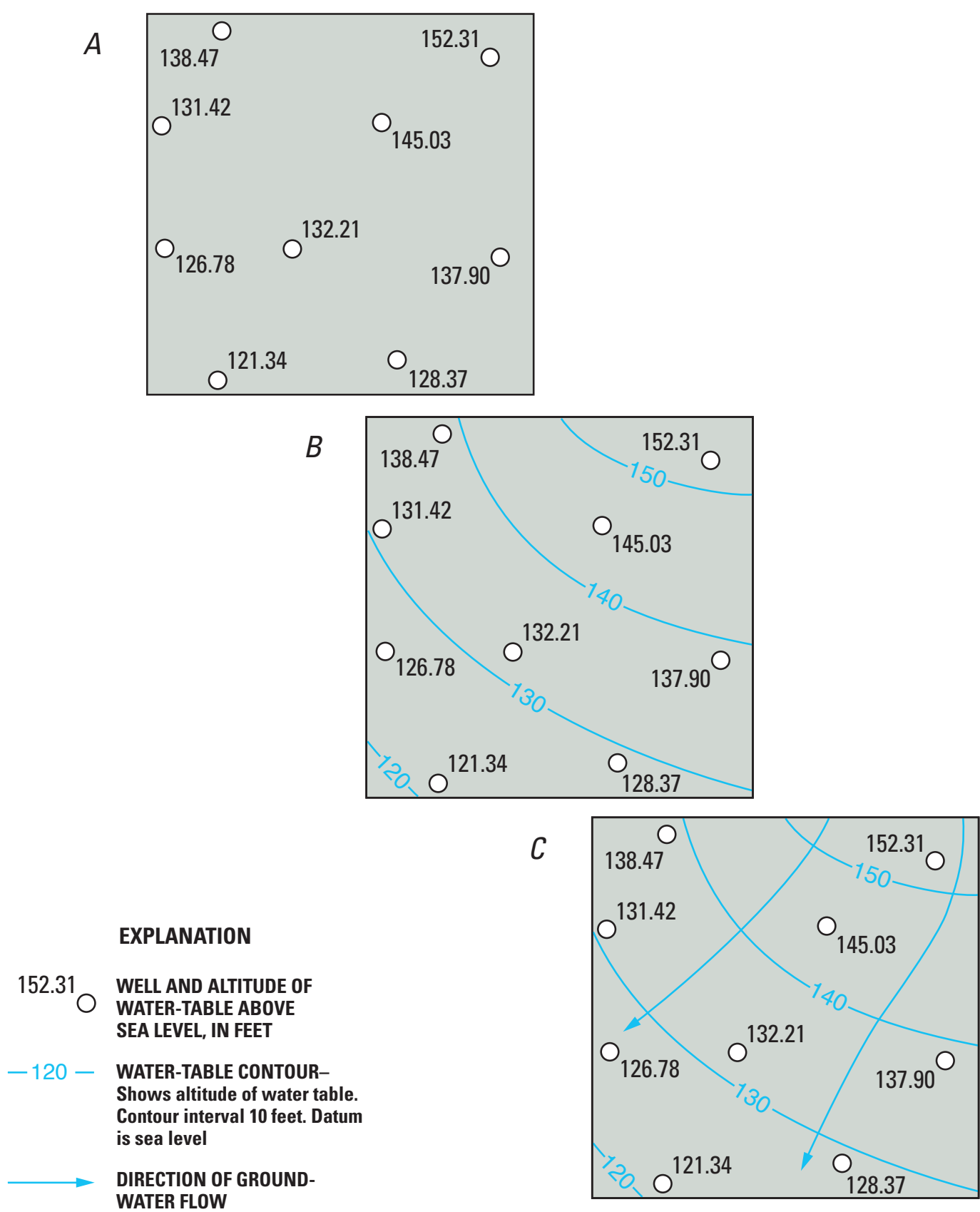

Figure 10. Example of how $A$, groundwater levels and $B$, water-table contours can be used to determine $C$, direction of groundwater flow. 


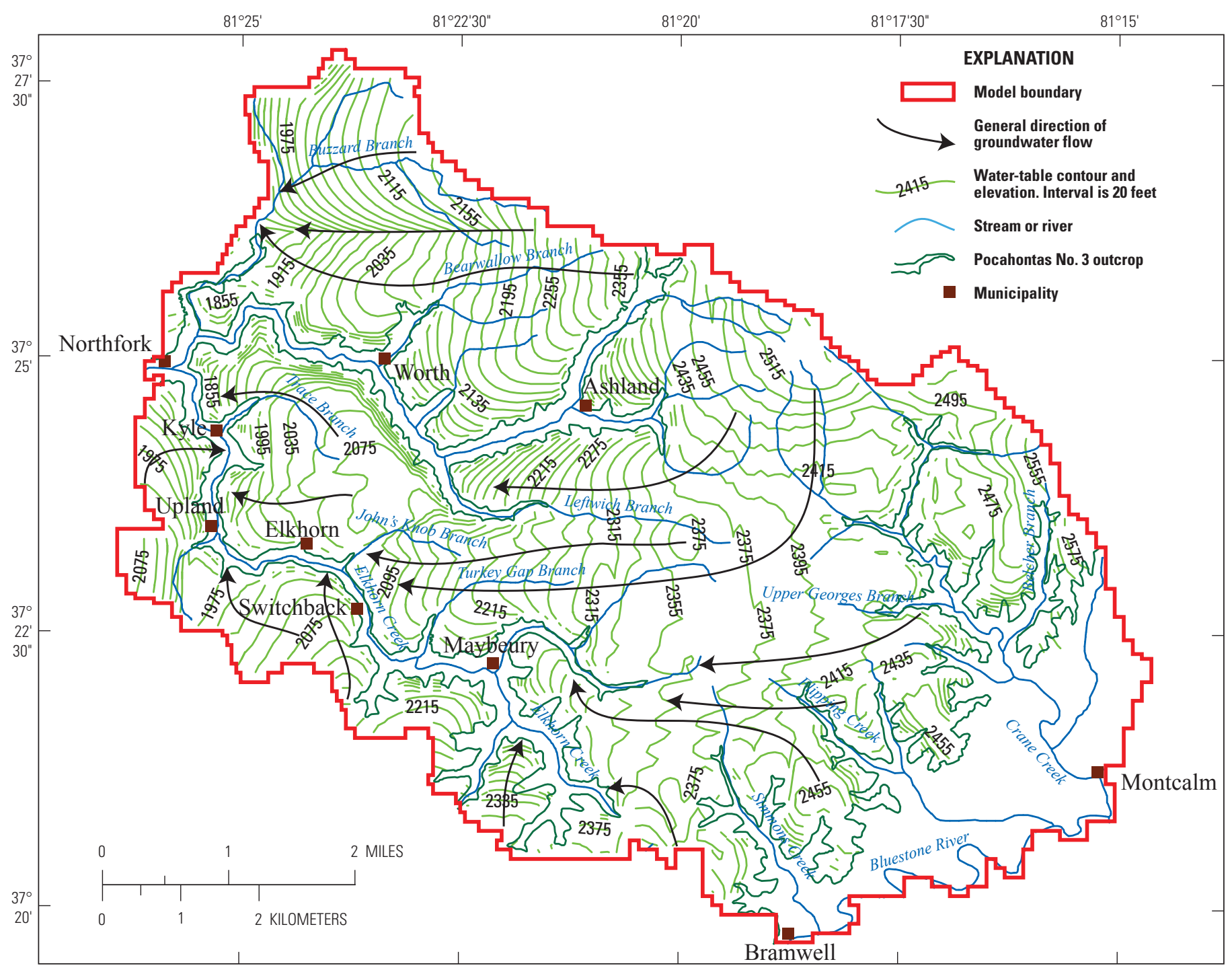

Base from U.S. Geological Survey digital data, 1:100,000,

1983, Universal Transverse Mercator projection, Zone 18

Figure 11. Simulated water levels for hydrologic conditions respective of the 70th percentile flow duration in layer 2 representing the Pocahontas No. 3 abandoned coal-mine aquifer of the groundwater-flow model developed for the Elkhorn area, McDowell County, West Virginia. (From Kozar and others, 2012)

scenarios of anticipated withdrawals. The same model was used to estimate groundwater recharge areas for the springs that serve as the primary source of water for the USGS facility at Leetown. A similar groundwater-flow model was developed for the Opequon Creek watershed (fig. 13), which incorporated parts of Jefferson and Berkeley Counties in West Virginia and Clarke and Frederick Counties in Virginia. Although particle tracking and drawdown analyses were not conducted as part of the Opequon Creek model, the model was later used by the WVDHHR to assess groundwater recharge areas to publicsupply springs and production wells in Jefferson and Berkeley Counties, West Virginia.

Hydraulic conductivity typically is derived from estimates of transmissivity, which are computed from aquifer tests or estimated from specific capacity test data. Transmissivity
(T) is hydraulic conductivity $(\mathrm{K})$ multiplied by the saturated thickness (b) of the aquifer. Specific capacity is the pumped discharge rate divided by the drawdown produced by pumping the well over a period of time. Such methods were used to produce statewide estimates of transmissivity for various geologic formations and groups in West Virginia (Kozar and Mathes, 2001). Table 2 summarizes statewide data available for transmissivity estimated from specific capacity test data (Kozar and Mathes, 2001). Specific capacity, transmissivity, and other data are presented in the statewide aquifer characteristics compilation (Kozar and Mathes, 2001), and transmissivity statistics are summarized in table 2 . The data can be used to determine which geologic formations tend to have low median transmissivity and which tend to have high median transmissivity. Depending on the rate of pumping $(\mathrm{Q})$, wells with low 

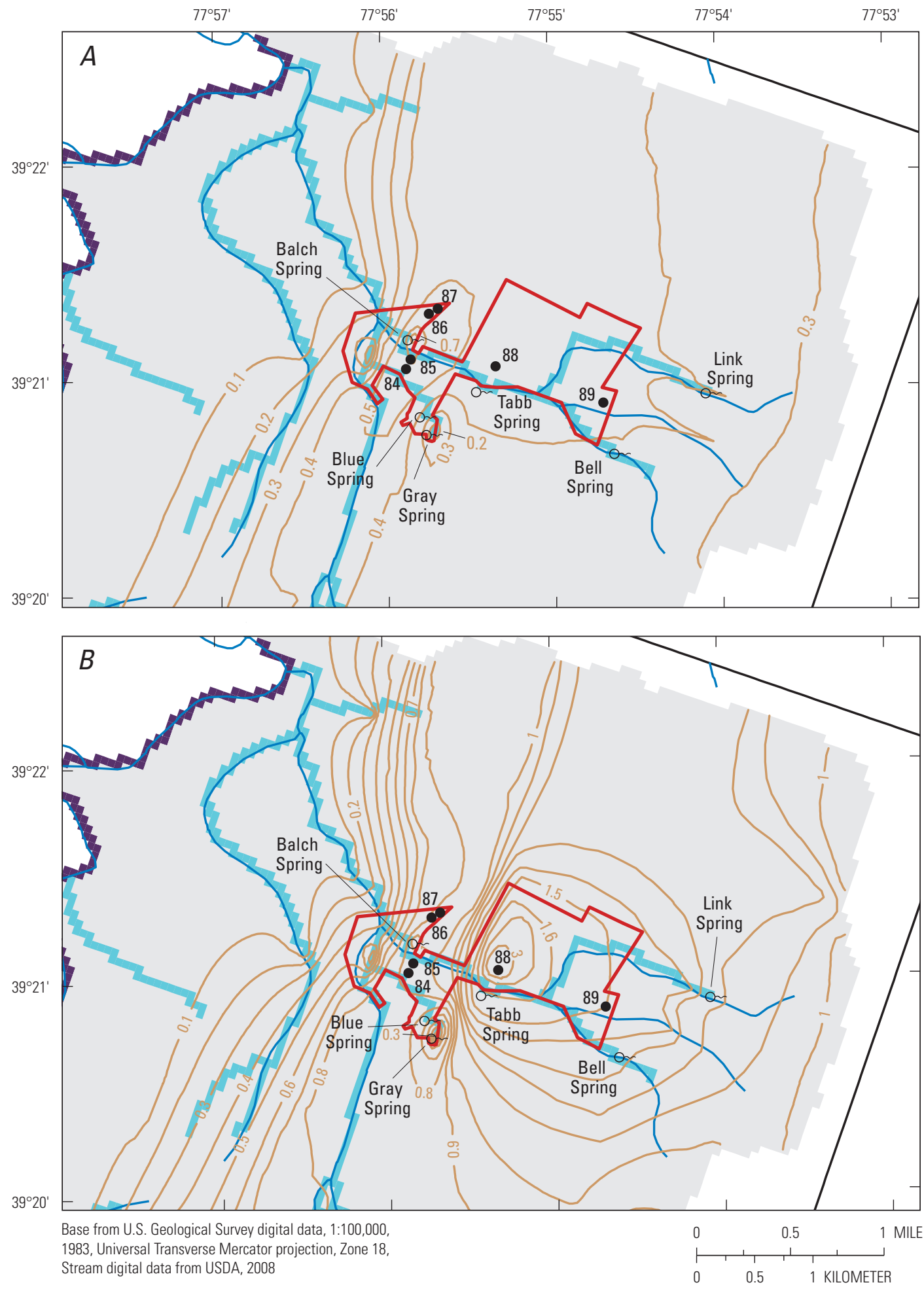

Stream digital data from USDA, 2008

EXPLANATION
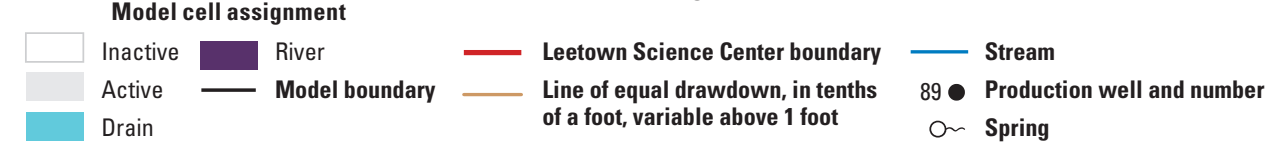

Figure 12. Simulated drawdown in the Leetown area, West Virginia, for $A$, pre-existing pumping conditions during a drought and $B$, resulting from the addition of production wells 87 and 88 pumping at 50 and 100 gallons per minute during a drought. (Kozar and others, 2007a) 


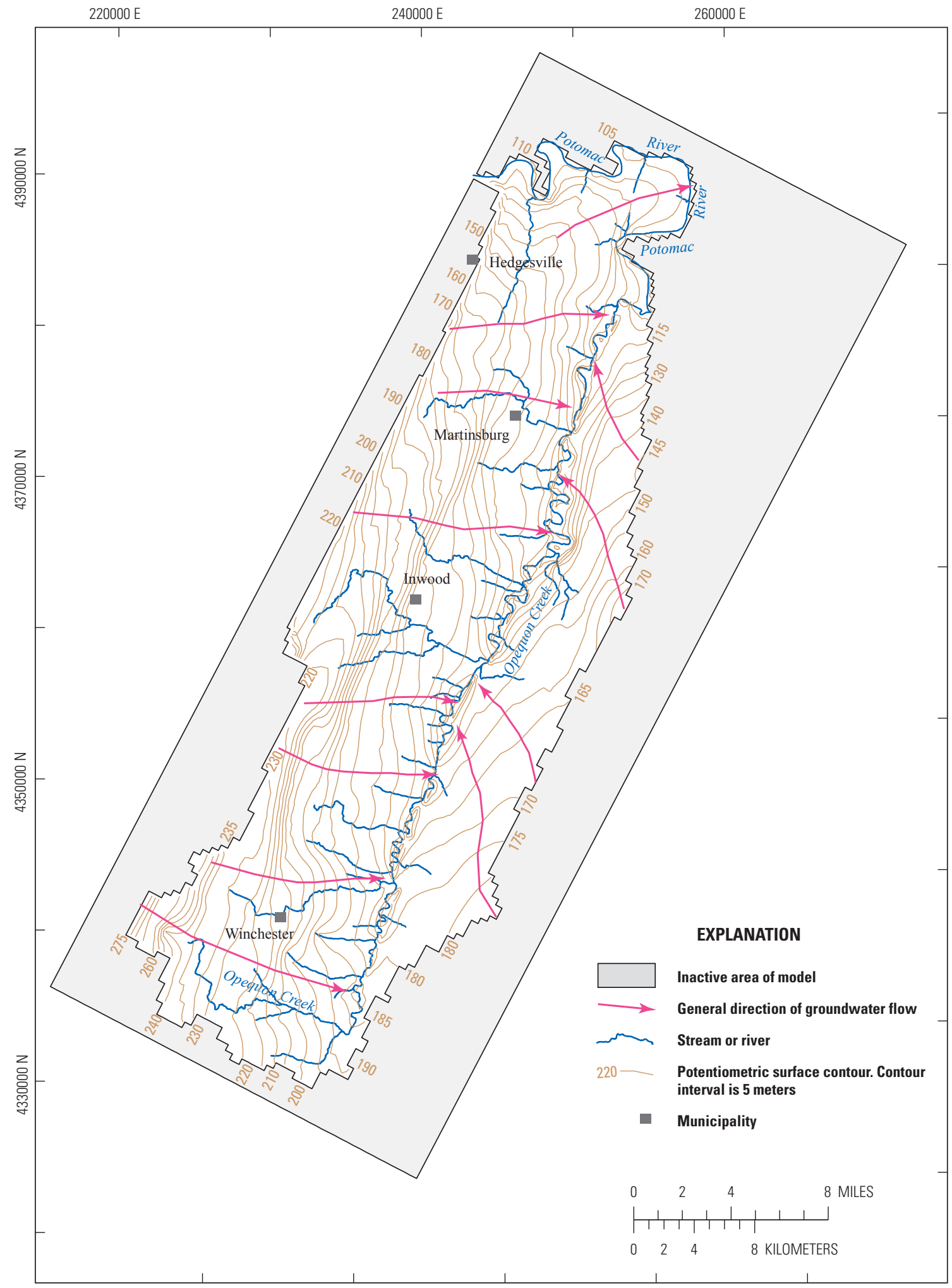

Base from U.S. Geological Survey digital data, Universal Transverse Mercator Projection, NAD83, Zone 18

Figure 13. Simulated potentiometric surface and generalized directions of groundwater flow for average hydrologic conditions in the Opequon Creek Watershed area, Virginia and West Virginia. (Kozar and Weary, 2009) 
hydraulic conductivity generally produce much smaller cones of depression than wells with high hydraulic conductivity (fig. 14). Examination of the transmissivity data presented in table 2 shows that all geologic formations across West Virginia have a wide range of transmissivity values. Thus, the transmissivity is controlled by the secondary porosity, owing to fractures within the geologic formations. These fractures may be the result of natural features, such as bedding planes, joints, stress-relief fractures, and faults.

Alternatively, fractures can be produced by human activity, such as coal mining, and can cause significant subsidence creating additional fractures in overburden strata, which can result in significant enhanced secondary permeability. The larger maximum transmissivity values for Pennsylvanian-age fractured-rock aquifers summarized in table 2 and shown in figure 5 likely are a result of subsidence fracturing as a result of coal mining. Cambrian-, Ordovician-, and Mississippianage karst limestone aquifers can also exhibit large maximum transmissivity values owing to enhanced secondary porosity resulting from conduit development (see the remarks column and associated maximum and median transmissivity data in table 2) that results from solution enlargement of fractures in limestone and dolostone aquifers. Aquifers with the highest median and maximum transmissivity values in West Virginia are the alluvial aquifers bordering the Ohio and Kanawha Rivers. Alluvial aquifers along other minor tributary streams in West Virginia are not often tapped as a source of water for public supply.

Therefore, alluvial, karst, and abandoned-coal-mine aquifers have the potential to generate large cones of depression and associated zones of contribution or recharge areas than the more fracture-dominated bedrock aquifers of Devonian age, such as those of the Oriskany Sandstone, Onondaga Group, Marcellus Formation, Mahantango Formation, Harrell Shale, Brallier Formation, and Hampshire Formation. Some wells in karst aquifers without conduit-dominated flow, and a large proportion of wells in unmined areas in Pennsylvanian- and Permian-age fractured-rock aquifers, may exhibit transmissivity values more associated with fractured-rock aquifers rather than karst or abandoned-coal-mine aquifers. As such, aquifer transmissivity within a geologic formation or group can vary by orders of magnitude (table 2); such data need to be evaluated for individual wells on a site-specific basis to determine the potential for a well to produce a large cone of depression around a pumped well with an associated large zone of contribution or recharge area. Generally however, karst aquifers, alluvial aquifers, and abandoned-coal-mine aquifers can have large cones of depression around pumped wells and associated

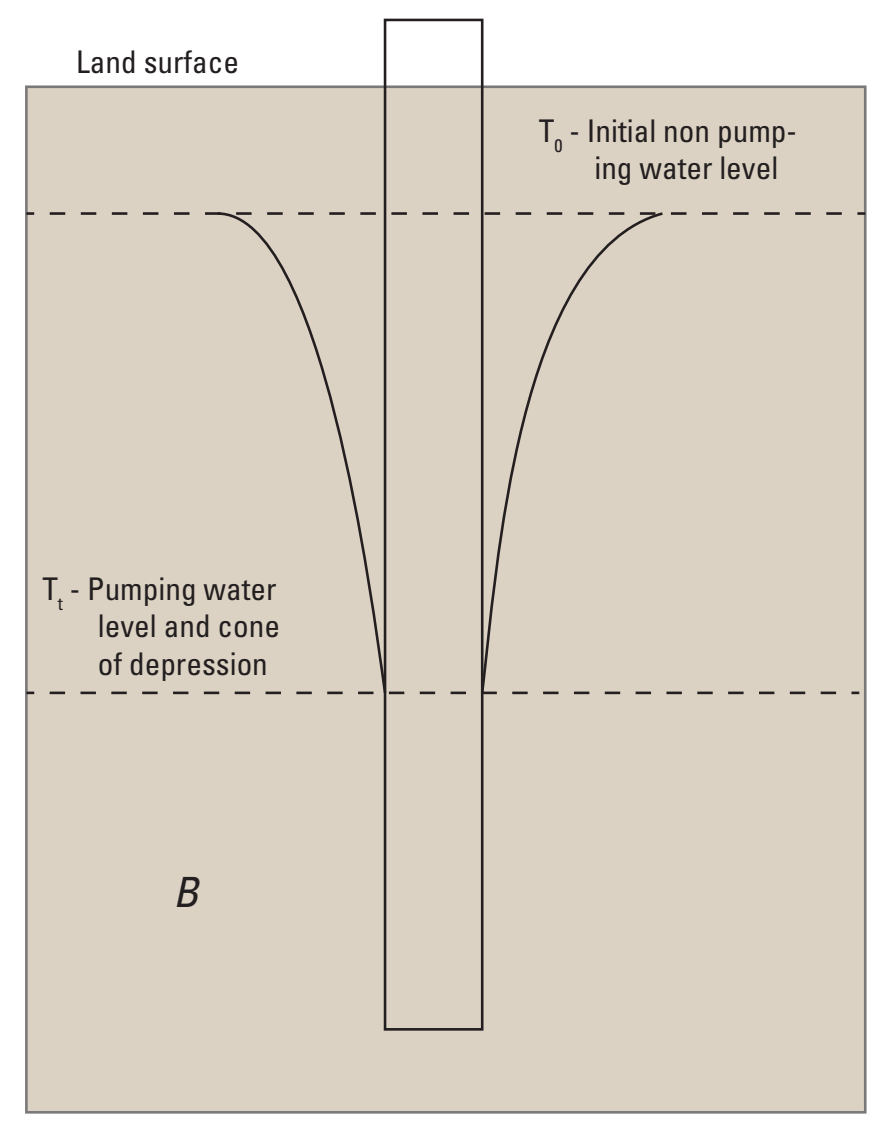

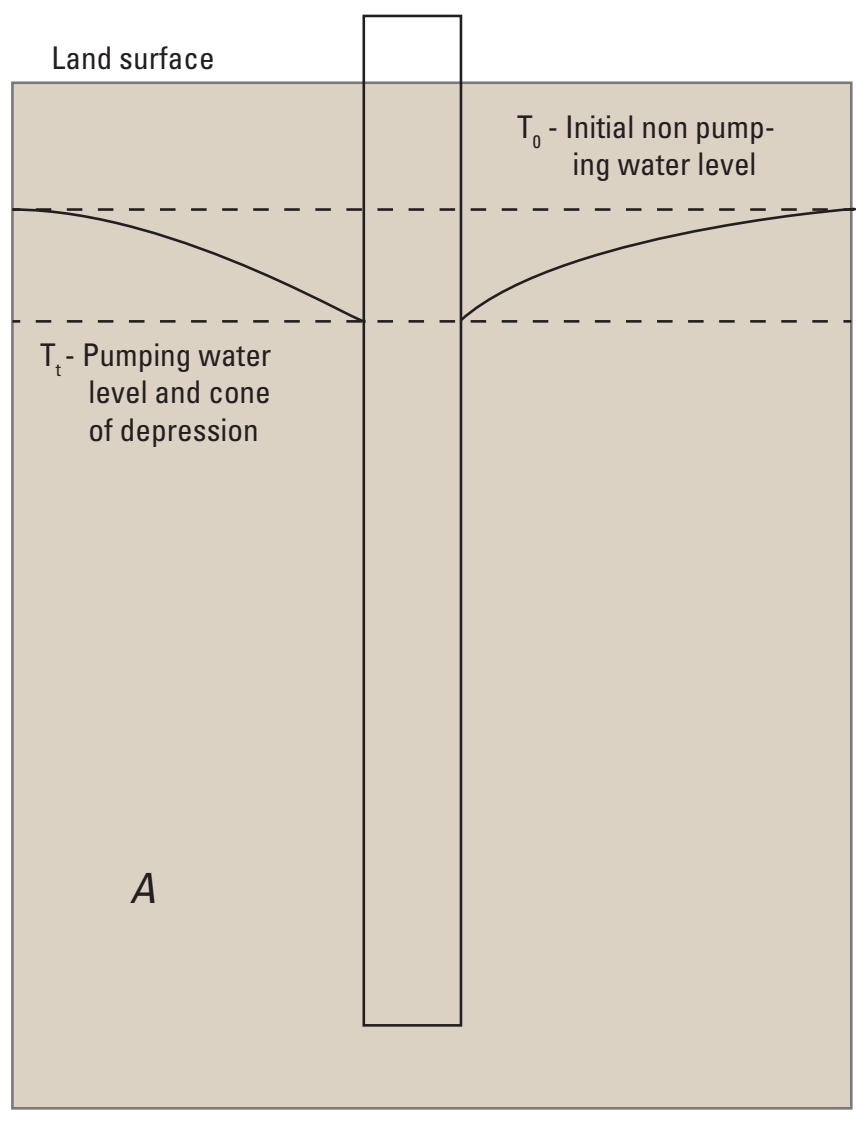

Figure 14. A, hypothetical high hydraulic conductivity in a well showing a broad shallow cone of depression and $B$, hypothetical low hydraulic conductivity in a well showing a much deeper and narrower cone of depression. (Modified from Freeze and Cherry, 1987) 
large zones of contribution and recharge areas. Multi-well aquifer tests are the best method to ascertain the potential size of a cone of depression around a pumped well and can be used in certain cases to estimate the zone of contribution and recharge area for a well. Numerical groundwater-flow models (as illustrated in figs. 12-14) are an even more powerful tool for assessing recharge areas and zones of contributions, especially where there are multiple wells in a well field or complex hydrogeology or boundary conditions occur. In the absence of numerical simulations, aquifer tests or even estimation of transmissivity from specific capacity test data can provide useful data for SWIGS determinations.

\section{Well-Construction Characteristics as a Factor for Assessing Vulnerability}

All available water-quality and microbial data for wells sampled in West Virginia were retrieved from the USGS water-quality database and merged with well-construction data (well depth and length of casing) retrieved from the USGS GWSI database to provide a comprehensive database for analysis (appendix 2). The merged data were used to make an assessment of well depth and length of casing in relation to microbial data (fecal coliform, total coliform, fecal streptococcus, and E. coli bacteria).

\section{Well Depth}

A plot of well depth in relation to concentrations of fecal coliform (fig. 15), total coliform, fecal streptococcus, and E. coli bacteria showed no correlation between concentrations of bacteria and overall depth of the well sampled. Therefore, well depth is not an appropriate criteria for determining whether or not an individual well may be identified as a SWIGS. As bacteria enter a well near the surface, characteristics such as length of the well casing and proper or inadequate well grouting are probably more important controls than the depth of the well when considering whether or not a particular well will be susceptible to contamination by bacteria from human or animal sources.

\section{Casing Length}

To investigate the role of well casing, and whether or not the length of casing is correlated to bacterial contamination in a well, a plot of casing length in relation to concentrations (fig. 16) of fecal coliform, total coliform, fecal streptococcus,

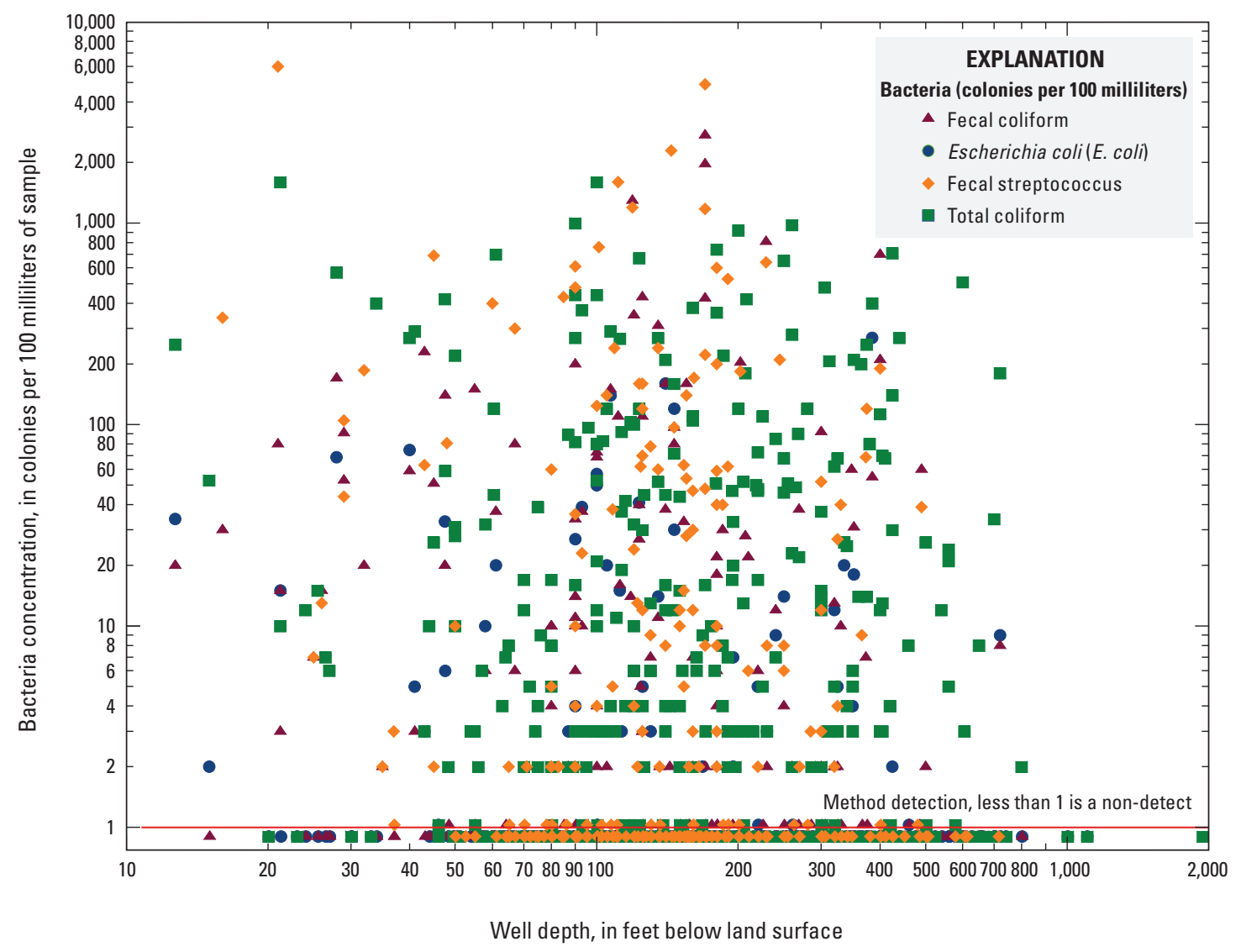

Figure 15. Relation of fecal coliform, fecal streptococcus, total coliform, and E. coli bacteria to well depth for selected wells in West Virginia. 


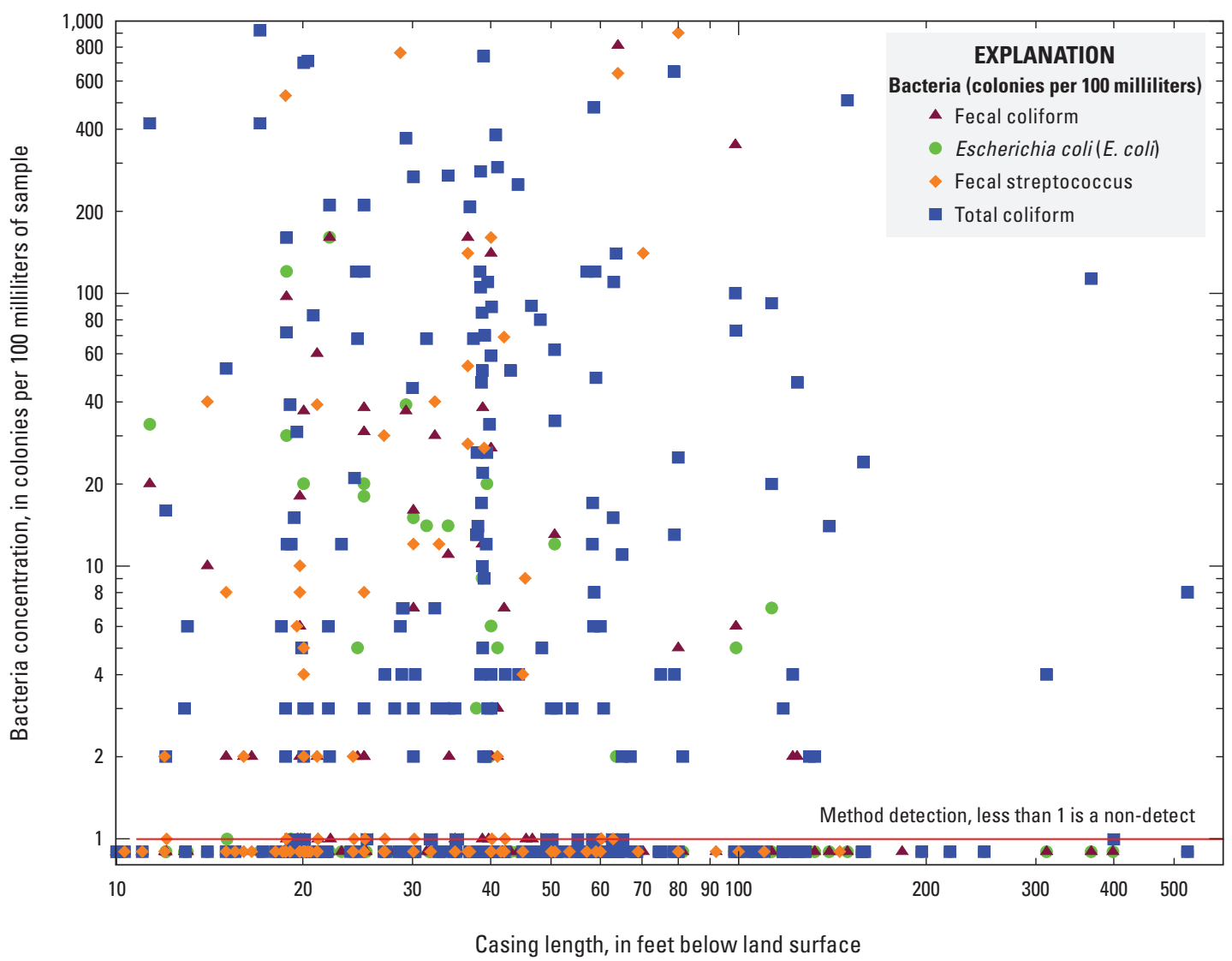

Figure 16. Relation of total coliform, fecal coliform, fecal streptococcus, and E. coli bacteria to length of well casing for selected wells in West Virginia.

and E. coli bacteria was generated. At first glance it appears that there is no relation between the length of the well casing and bacteria concentrations. However, total coliform bacteria are ubiquitous in the environment and can be detected even in wells with long well casings. Total coliform is probably not a good measure by which to assess potential contamination of a well owing to its common occurrence in soil. Bacteria that are more specific to humans and warm-blooded animals, such as fecal coliform, E. coli, and fecal streptococcus are much better indicators of potential pathogenic bacteria and other organisms, such as Cryptosporidia, Giardia lamblia, and viruses, than are total coliform bacteria. As a result, total coliform bacteria were omitted, and fecal coliform, E. coli, and fecal streptococcus bacteria were plotted in relation to length of well casing (fig. 17). There is a distinct difference at a casing length of about $45 \mathrm{ft}$. Detections of indicator bacteria were more common in wells with casing lengths less than or equal to $45 \mathrm{ft}$ than in wells with casing lengths of more than $45 \mathrm{ft}$. For wells with casings lengths greater than $45 \mathrm{ft}$, only 2.3 percent had detectable concentrations of $E$. coli bacteria, and only 4.7 percent had detectable concentrations of fecal coliform bacteria. For wells with casing lengths less than $45 \mathrm{ft}, 13.1$ percent had detectable concentrations of E. coli, and 16.5 percent had detectable concentrations of fecal coliform bacteria.

A common convention for wells drilled prior to about 1985 was to drill as shallow a well as needed and to case wells only to sufficient depth to isolate regolith, shallow unconsolidated sediments, and shallow fractures from more competent bedrock. In 1985 the WVDHHR began regulating residential well construction and required permits to be filed and well-completion reports to be submitted by the well driller upon completion of the well (West Virginia Bureau for Public Health, 1984). Prior to 1993, there were no statewide regulations regarding grouting of residential water wells, but a few counties in West Virginia's eastern panhandle had enacted mandatory well grouting. In 2008 the WVDHHR mandated that all new residential wells be grouted (West Virginia Department of Health and Human Resources, 2008). Therefore, since the data plotted in figures 15,16 , and 17 include a significant proportion of wells drilled prior to 1993, a similar plot generated with only wells of newer construction may show significantly fewer detections of bacteria. Regardless, length of casing may be a factor to consider in determining whether or not a particular well can be considered a SWIGS. 


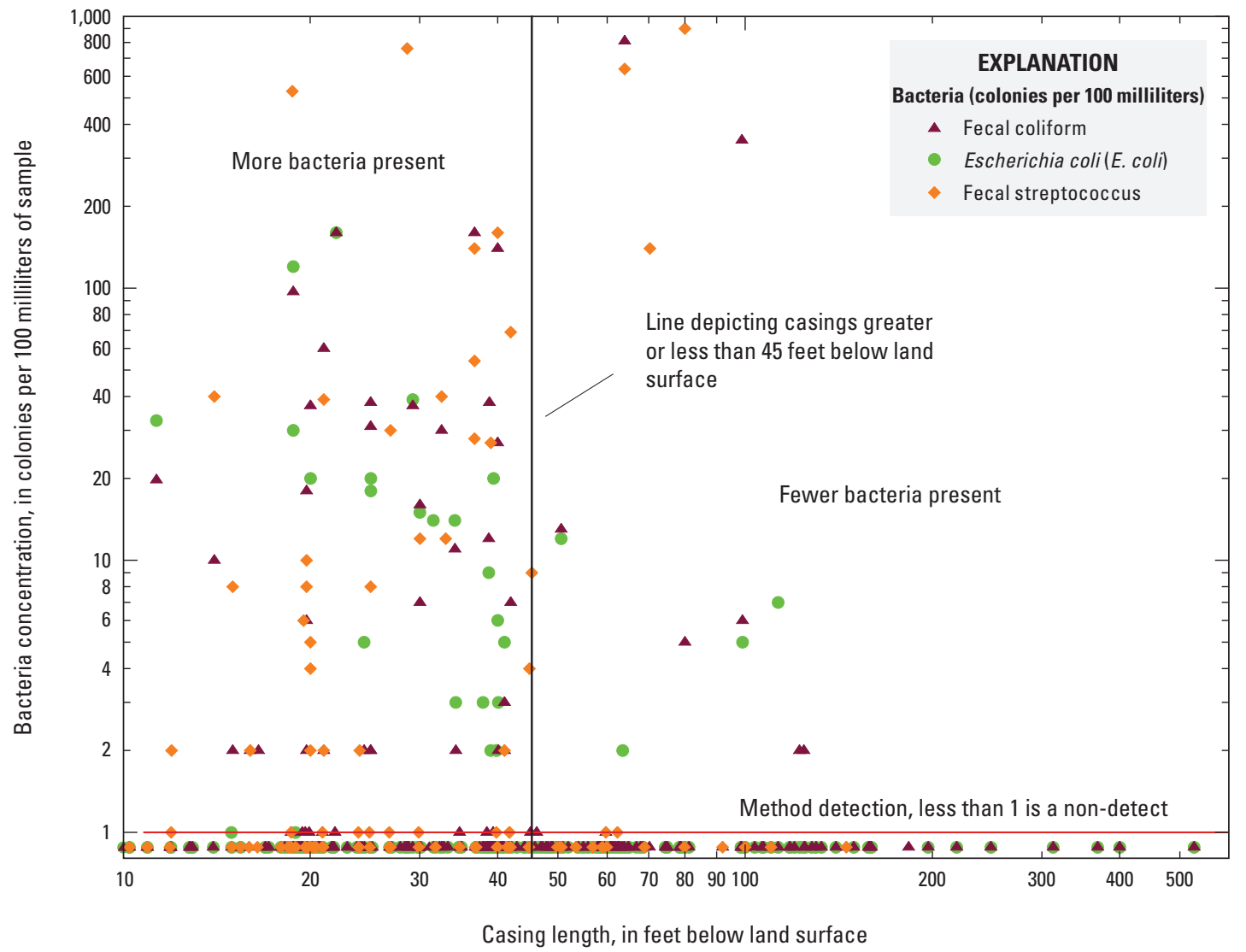

Figure 17. Relation of fecal coliform, fecal streptococcus, and E. coli bacteria to length of well casing for selected wells in West Virginia.

\section{Water-Quality and Microbial Data as a Factor for Assessing Vulnerability}

Water-quality characteristics that may be used for assessing SWIGS are similar to those developed to assess GWUDIs and include anthropogenic sources, such as indicator bacteria (total coliform, fecal coliform, fecal streptococcus, and E. coli), nitrate, and natural variation in groundwater temperature. Bacteria and nitrate may be derived from human waste via septic system return flows and leaking or faulty sewers, and animal sources, such as manure used as a fertilizer for agriculture and commonly present on animal feedlots and (or) pastures. Fecal waste from wildlife, such as deer, geese, bear, raccoons, beaver, and other animals, are an additional source of fecal bacteria and potential pathogens such as Giardia lamblia and Cryptosporidia. Additional anthropogenic compounds that may potentially be used to identify vulnerable aquifers and wells include synthetic organic chemicals, such as pesticides, fertilizers, VOCs, and CFCs. Other microbial indicators such as enterococci, coliphage, and microscopic particulate analyses also can be useful in assessing potential SWIGS wells or springs. Unfortunately, data for enterococci, coliphage, Cryptosporidia, and Giardia lamblia are sparse and not readily available for SWIGS determinations unless previously collected for a municipal water system as part of the GWUDI process. Data for indicator bacteria and nitrate, and to a lesser extent VOCs and CFCs, are more readily available and may be used in the SWIGS determination process. Other non-anthropogenic constituents, such as iron, manganese, and sulfate, can yield useful data for SWIGS determinations, primarily with respect to shallow redox processes indicative of shallow groundwater-flow processes, but lack of quantitative redox data leads to difficulty in use of such data for determining SWIGS. Thus nitrate, bacteria, VOCs, pesticides, and CFCs are the most reliable water-quality data for SWIGS determinations in West Virginia.

\section{Bacteria}

Results of bacterial tests for wells and springs sampled for the AMBGWMN (Chambers and others, 2012) include results for total coliform, fecal coliform, and E. coli bacteria. These statewide analyses provide direct observations of well and aquifer vulnerability to indicator bacteria and provide a good predictor of which aquifers within the State are intrinsically susceptible to contamination by associated pathogens, 
such as Giardia lamblia, Cryptosporidia, Legionella, viruses, and certain strains of $E$. coli $(\mathrm{O} 157: \mathrm{H7})$, as a result of activities occurring at the land surface or within the recharge area to a well. The presence of fecal coliform bacteria in a well is a good indicator that the well has been contaminated by fecal material; therefore, the potential for the presence in a well of associated pathogens from activities occurring at the land surface or in the recharge area to a well is high.

A plot of total coliform bacteria (fig. 18) shows that total coliform presence in well water in West Virginia is common. Because total coliform bacteria are present in soil as well as in fecal wastes, the presence of total coliform bacteria is a poor predictor of the presence of fecal bacteria and other pathogens. Note that only 26 of 295 sites (8.8\%) sampled (all wells, no springs) contained total coliform bacteria in excess of the 100-col/100-mL criteria used by the WVDHHR for identification of potential GWUDI sites.

Fecal coliform bacteria are a subset of total coliforms and are primarily derived from warm-blooded animals, including humans. Results of fecal coliform bacterial tests for wells and springs sampled for the AMBGWMN (fig. 19) show that fecal coliform contamination of wells in West Virginia is not common (Chambers and others, 2012). Only 32 of 319 sites sampled $(10.0 \%)$ contained fecal coliform bacteria. Springs seem to be especially vulnerable, with fecal coliform bacteria detections in 6 of 9 spring samples (67 percent) and 3 of 9 springs having concentrations exceeding $15 \mathrm{cols} / 100 \mathrm{~mL}$. If bacteria distribution for wells only is analyzed, because springs are

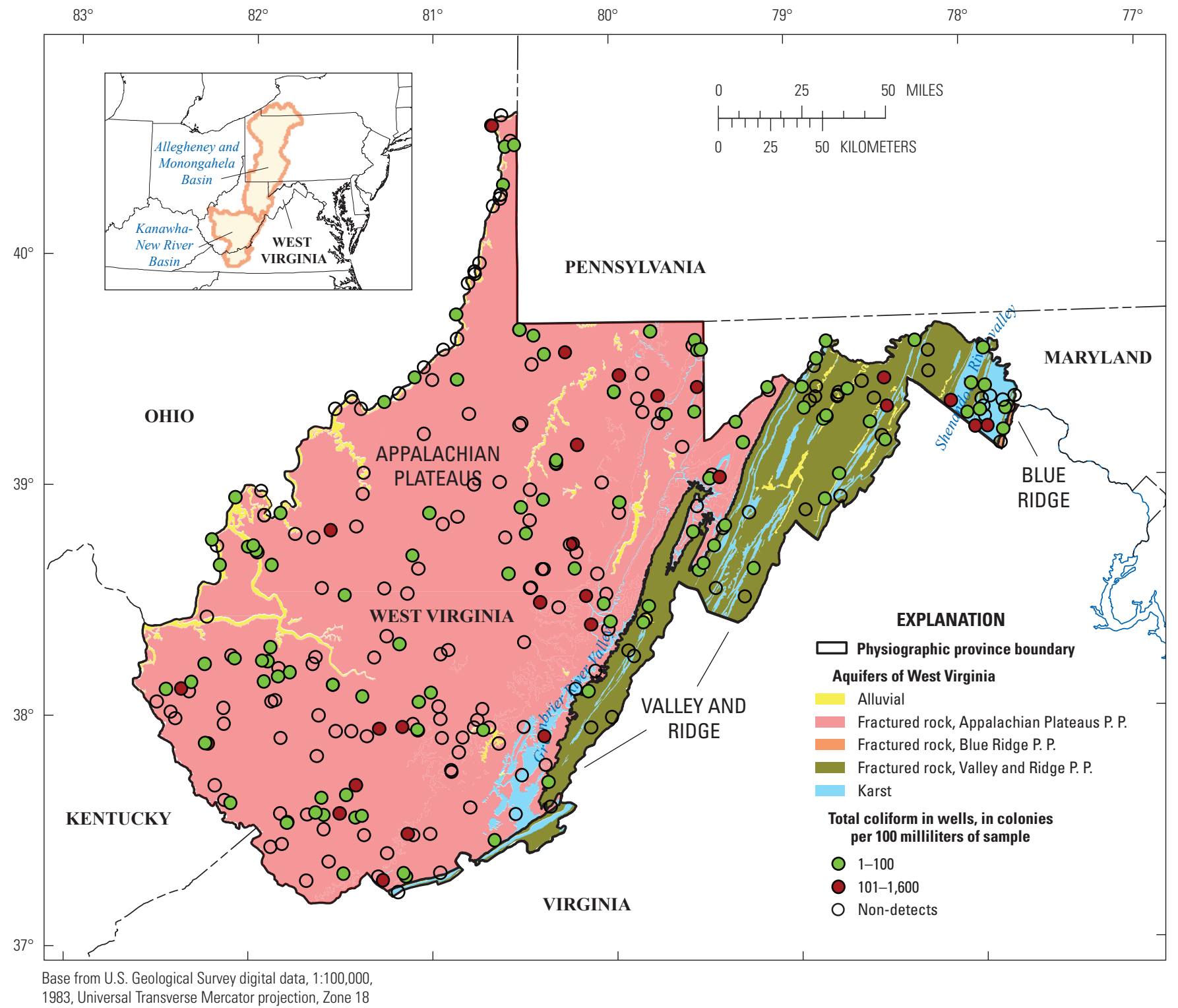

Figure 18. Distribution of total coliform bacteria in West Virginia's major aquifers, 1993-2008. (Data from Chambers and others, 2012; P. P., Physiographic Province) 


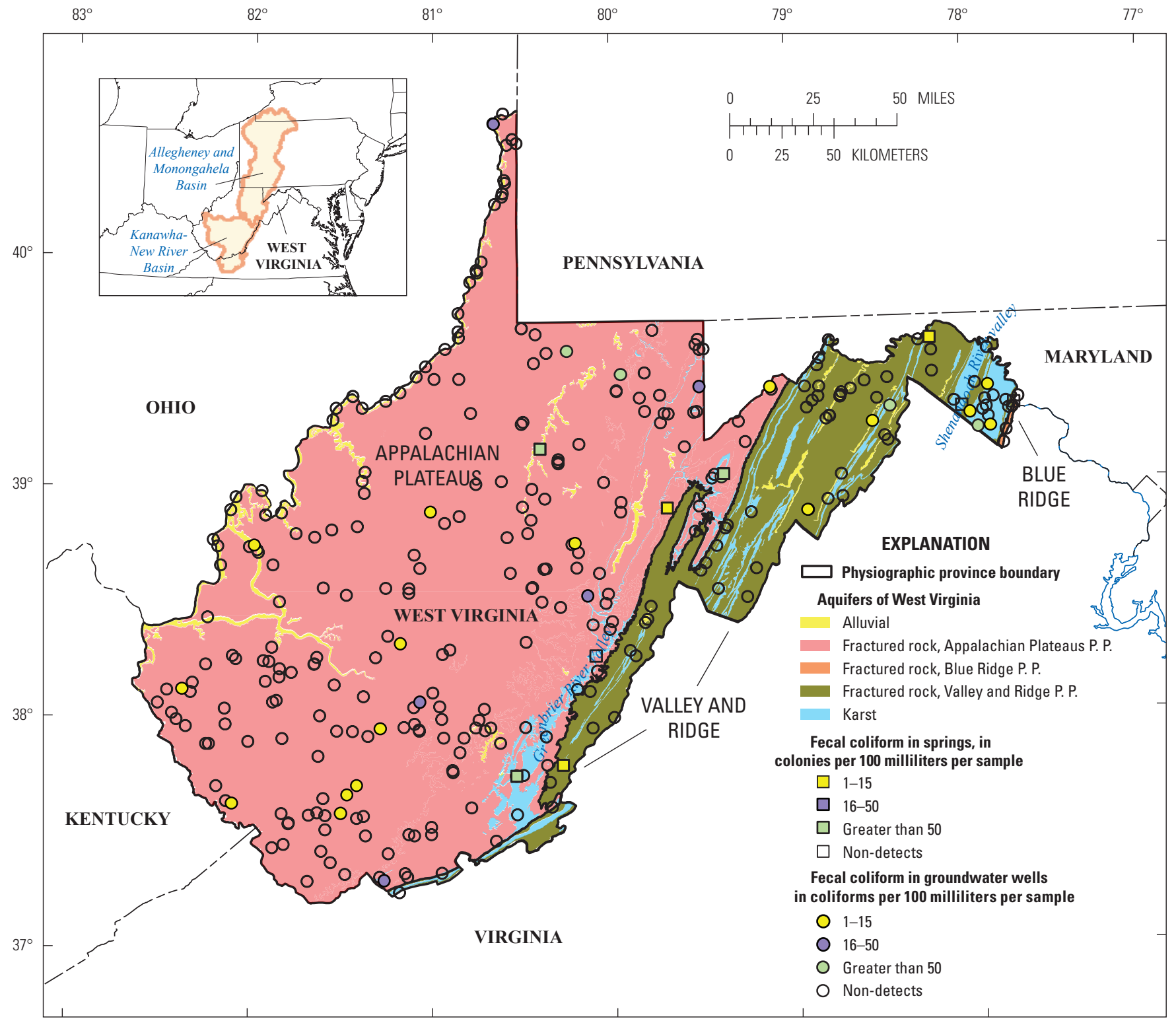

Base from U.S. Geological Survey digital data, 1:100,000,

1983, Universal Transverse Mercator projection, Zone 18

Figure 19. Distribution of fecal coliform bacteria in West Virginia's major aquifers, 1993-2008. (Data from Chambers and others, 2012; P. P., Physiographic Province)

considered a surface-water source by the WVDHHR, only 26 of 310 wells sampled $(8.4 \%)$ contained fecal coliform bacteria, and only 11 of $310(3.5 \%)$ contained fecal coliform bacteria in excess of the 15-col/100-mL criteria used by the WVDHHR for identification of potential GWUDI sites.

E. coli bacteria are a specific class of bacteria within the coliform group, and certain strains are known pathogens. $E$. coli bacteria outbreaks can cause large numbers of people to become sick, and the presence of certain strains of E. coli in food or drinking water poses a mortality risk in persons with suppressed immune systems, such as the elderly, infants, and individuals with long-term illnesses. The presence of E.coli bacteria in source water at significant concentration is a serious potential health risk. Results of tests for $E$. coli bacteria in wells and springs sampled for the AMBGWMN (fig. 20) show that $E$. coli contamination of wells in West Virginia is not common (Chambers and others, 2012). Only 18 of 206 sites (8.7\%) sampled (all wells, no springs) had detectable concentrations of $E$. coli bacteria, and only 9 of 206 (4.4\%) sites had concentrations greater than the $15-\mathrm{col} / 100-\mathrm{mL}$ threshold used to identify potential GWUDI sites. 


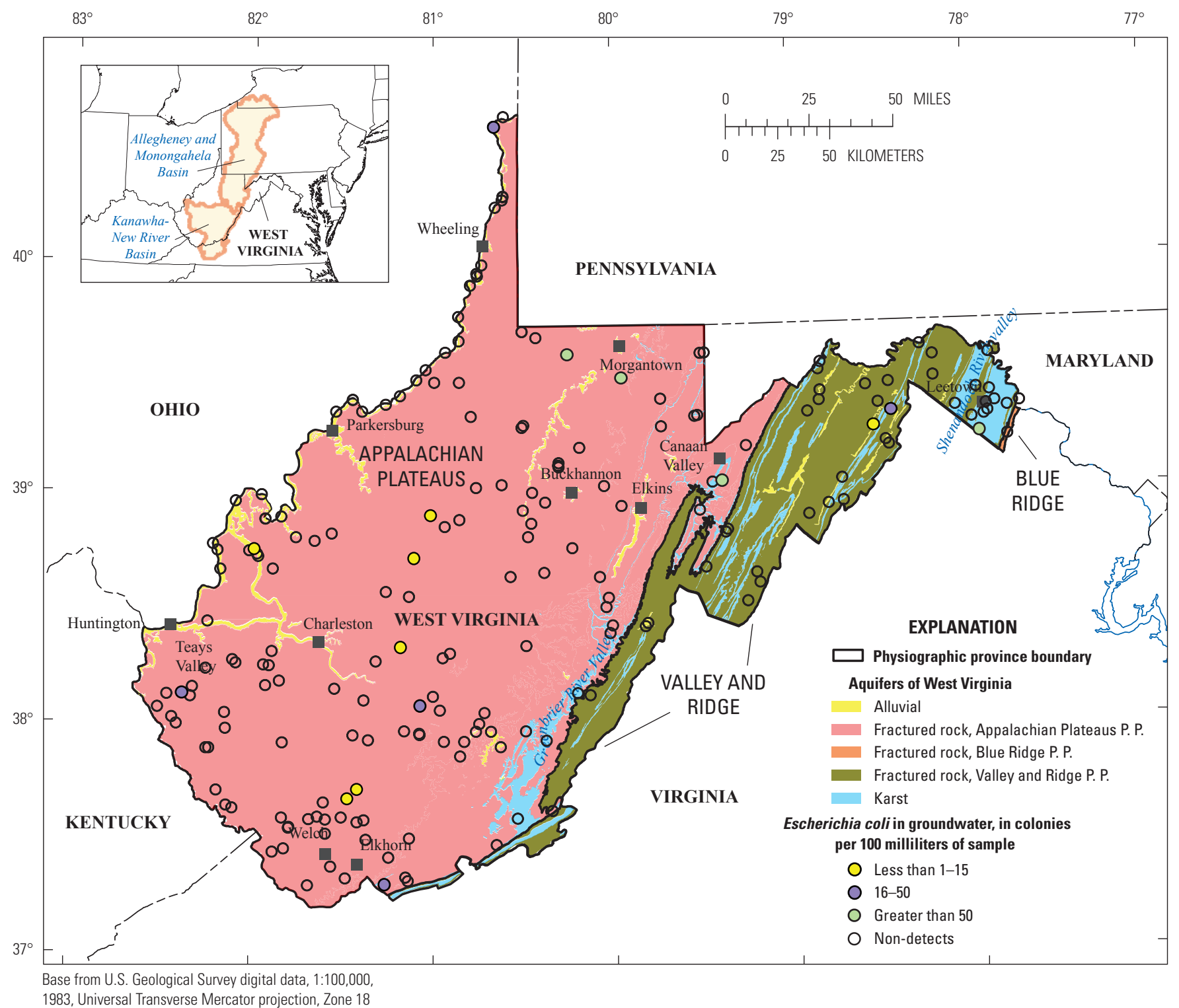

Figure 20. Distribution of E. coli bacteria in West Virginia's major aquifers, 1993-2008. (Data from Chambers and others, 2012; P. P., Physiographic Province)

Examination of the areal distribution of fecal coliform and $E$. coli bacteria across West Virginia (figs. 19 and 20) reveals two interesting trends. First, only 2 of the $34(5.9 \%)$ wells sampled in alluvial aquifers along the Ohio or Kanawha Rivers had a positive detection of $E$. coli bacteria, and only 2 of the $40(5 \%)$ wells sampled had a positive detection of fecal coliform bacteria. One of the detections of bacteria was in a sample collected in Chester, West Virginia, which derives it water supply from a wooden infiltration gallery completed in alluvial sediments along the river bank, rather than from drilled, cased, and screened wells. The open nature of the infiltration gallery makes the site more susceptible to contamination than drilled, cased, and screened wells in similar sediments. Therefore, only 1 of 42 (2.4\%) drilled, cased, and screened wells in alluvial settings had a detection of either total coliform or $E$. coli bacteria, and neither concentration exceeded the 15-col/100-mL criteria for GWUDI determination. This result is similar to the trend documented in a previous investigation (Jeffords, 1945). The alluvial sediments act as a large sand filter naturally retarding the movement of bacteria from adjacent river water into alluvial wells. Therefore, even though alluvial aquifers may be moderately to highly intrinsically susceptible to contamination, they are not highly vulnerable to bacterial contamination. Other constituents such as nitrate, however, are soluble in water and easily pass through the alluvial sediments (to be discussed in the following "Nitrate" section). 
The second apparent trend is that wells in karst regions of the State, including Canaan Valley and the Shenandoah River and Greenbrier River valleys, had more frequent positive detections ( 8 of 20 wells sampled, or $40 \%$ ) of either fecal coliform or $E$. coli bacteria than other aquifers within the State. Because karst aquifers are the most intrinsically susceptible aquifers to contamination in West Virginia, such a high percentage of wells with fecal coliform or E. coli bacteria detections may warrant additional evaluation as part of future SWIGS determinations.

\section{Nitrate}

Nitrate is a common contaminant found in agricultural areas; typically, it is derived from manure and synthetic fertilizers used on crops. Another common source of nitrate is fecal wastes from animal feedlots and pastures. Septic effluent from residential septic systems is another common source of nitrate. The EPA established an MCL for nitrate in public drinking water of $10 \mathrm{mg} / \mathrm{L}$ because of the risk of methemoglobinemia, commonly referred to as blue baby syndrome. Methemoglobinemia is a serious health condition that affects the ability of the blood to transport oxygen and is potentially fatal for infants (EPA, 2015).

Nitrate is a water soluble chemical compound that is easily transported in groundwater. As such, in addition to being a good indicator of agricultural contamination, its presence can also be used as a surrogate to predict potential contamination from other water soluble chemical compounds, including some VOCS, pesticides, and semi-volatile industrial compounds. However, the absence of nitrates does not necessarily mean the absence of vulnerability to dissolved anthropogenic compounds because nitrate is converted to nitrogen gas in reducing groundwater environments, whereas other contaminants can persist in either reduced or oxidized environments. For the USGS AMBGWMN data, nitrate is expressed as combined nitrate plus nitrite. Since nitrite is a minimal component of the total of nitrate plus nitrite, the nitrate plus nitrite can be considered representative of total nitrate.

Results of nitrate plus nitrite tests of samples from wells and springs for the AMBGWMN (fig. 21) show that nitrate contamination in West Virginia is clustered primarily in two principal hydrogeologic units (aquifers): alluvial aquifers bordering the Ohio River and karst aquifers in the CambrianOrdovician limestones of the Shenandoah River valley in extreme eastern West Virginia, and in a few areas within the Greenbrier River valley karst region. Only one site, an alluvial well near Point Pleasant, West Virginia, contained nitrate plus nitrite concentrations in excess of the $10-\mathrm{mg} / \mathrm{L}$ as N MCL. Five of $29(17 \%)$ wells completed in the Ohio River alluvial aquifer had samples with elevated nitrate plus nitrite concentrations above background greater than or equal to $5 \mathrm{mg} / \mathrm{L}$. Five wells sampled had non-detectable concentrations of nitrate plus nitrite in the Ohio River alluvium. None of three wells sampled in Kanawha River alluvium had detectable concentrations of nitrate plus nitrite. Four of 16 wells (25\%) in the Cambrian-Ordovician karst aquifer in West Virginia's eastern panhandle had elevated concentrations of nitrate plus nitrite greater than or equal to $5 \mathrm{mg} / \mathrm{L}$. None of the $11(0 \%)$ wells sampled in Canaan Valley or the Greenbrier River valley had elevated concentrations of nitrate plus nitrite greater than or equal to $5 \mathrm{mg} / \mathrm{L}$. Fractured-rock aquifers within the Appalachian Plateaus and Valley and Ridge Physiographic Provinces typically had non-detectable or very low concentrations of nitrate plus nitrite (fig. 21) with a maximum concentration of only $3.01 \mathrm{mg} / \mathrm{L}$.

On the basis of statewide nitrate data, only the karst aquifers in the Cambrian- and Ordovician-age rocks of the Shenandoah River valley, karst aquifers in the Greenbrier River valley, and alluvial aquifers along the Ohio River are vulnerable to nitrate contamination. Because nitrate is typically derived from fertilizers and manure applied in agricultural areas, it is not surprising that nitrate is common in the aforementioned aquifers, as all are in areas of moderate to heavy agricultural activity. As mentioned previously, because nitrate is soluble in water, it can serve as a good indicator of potential contamination by other similar soluble chemical compounds, such as most VOCs and pesticides, and some industrial chemicals.

\section{Pesticides}

Seventy-seven sites were sampled during 1993-2008 for a suite of 52 pesticides as part of routine sampling for the AMBGWMN (Chambers and others, 2012). Statewide distribution of pesticides detected is shown in figure 22 . Examination of the distribution of pesticide detections in West Virginia (fig. 22) shows a cluster of pesticide detections in the Cambrian-Ordovician karst aquifer in the Shenandoah River valley in extreme eastern West Virginia. Pesticides were detected in samples from 11 of 12 (92\%) wells completed in the karst aquifer in the Shenandoah River valley; 10 of 12 wells sampled had three or more different pesticides detected. One of two wells sampled in the Greenbrier River valley contained detectable concentrations of three or more pesticides; the other well had no detectable concentrations of pesticides. In addition, 3 of 15 wells (20\%) sampled in the Ohio River alluvial aquifer had one or more detections of pesticides. Three wells were sampled in the Kanawha River alluvial aquifer, but none contained detectable concentrations of pesticides. Sporadic pesticide detections were found elsewhere in the State; samples from 6 of $27(22 \%)$ wells completed in fractured-rock aquifers of the Appalachian Plateaus had detectable concentrations of one or more pesticides. No clear association was found between pesticide detections and hydrogeologic terrain other than for the Cambrian-Ordovician karst aquifer in the Shenandoah River valley. A sample from only 1 of $16(6.3 \%)$ wells in the fractured-rock aquifers of the Valley and Ridge Physiographic Province had detectable concentrations of one or more pesticides. Note that even though there is a high occurrence of pesticide detections for wells in the karst aquifer in the Shenandoah River valley, and 


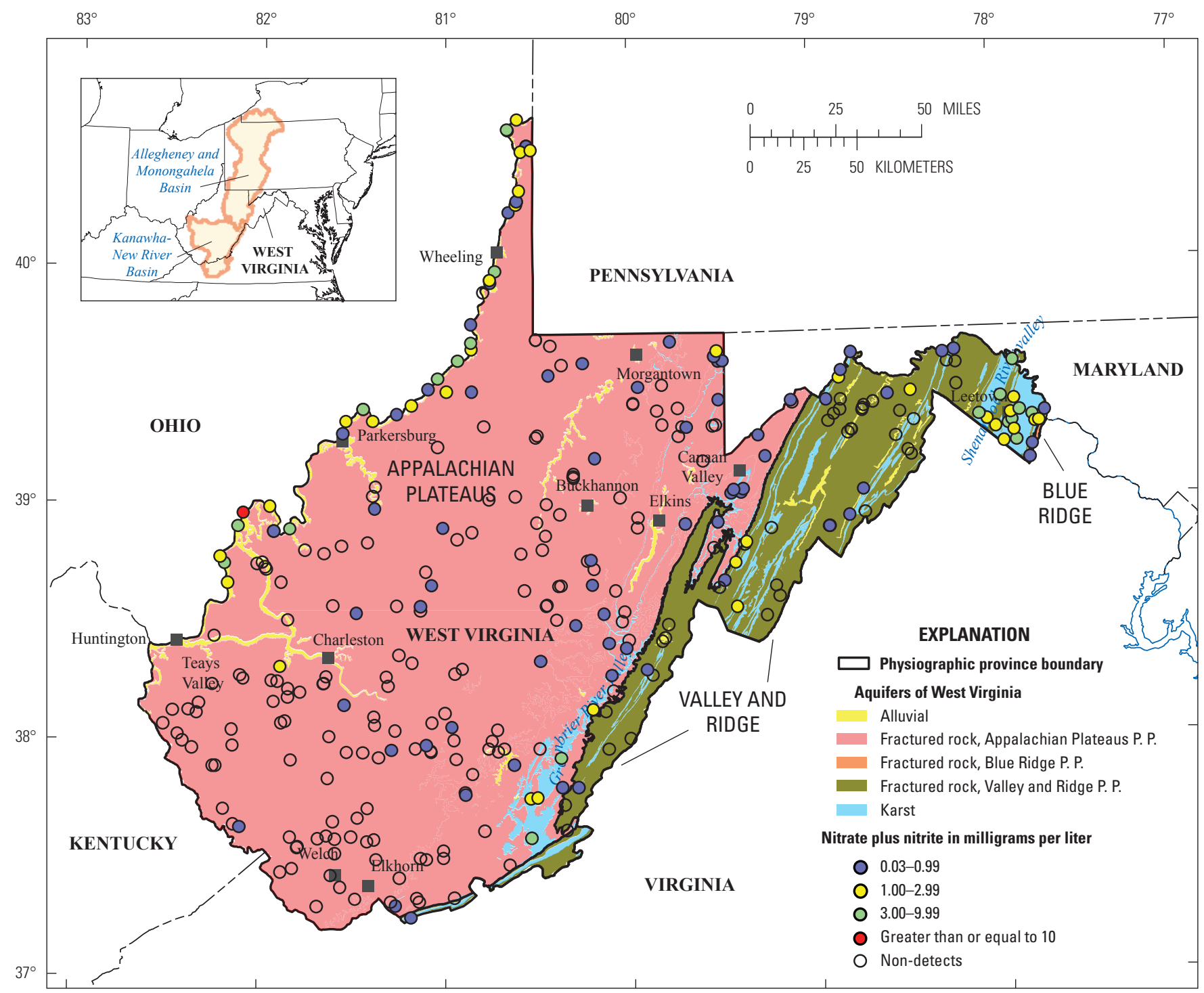

Base from U.S. Geological Survey digital data, 1:100,000,

1983, Universal Transverse Mercator projection, Zone 18

Figure 21. Distribution of nitrate plus nitrite in West Virginia's major aquifers, 1993-2008. (Data from Chambers and others, 2012; P. P., Physiographic Province)

at a few sporadic sites elsewhere, none of the concentrations in samples exceeded drinking water criteria (MCLs and HBSLs), which have been established for 11 of the 12 pesticides that were detected (Chambers and others, 2012).

\section{Volatile Organic Compounds}

VOCs are synthetic organic chemical compounds commonly used in industrial processes, dry cleaning operations, solvents, and household chemicals. Their presence in groundwater can be problematic if concentrations exceed drinking water standards. To ascertain vulnerability to VOCs of West
Virginia's major aquifers, the USGS sampled 281 wells for 34 VOCs between 1993 and 2008 as part of the AMBGWMN and other investigations. Of the 281 wells sampled, $210(75 \%)$ contained no detectable concentrations of VOCs, and 71(25\%) contained detectable concentrations of at least one VOC. Of the 71 wells with detections, $2(3 \%)$ contained a detectable concentration of only 1 VOC, 17 (24\%) contained detectable concentrations of 2 VOCs, and $12(17 \%)$ contained detections of 3 or more VOCs. A map showing the distribution of VOCs (fig. 23) indicates that alluvial aquifers along the Ohio River have a high proportion of wells with detectable VOCs; 15 of 25 wells (60\%) had detectable concentrations of 


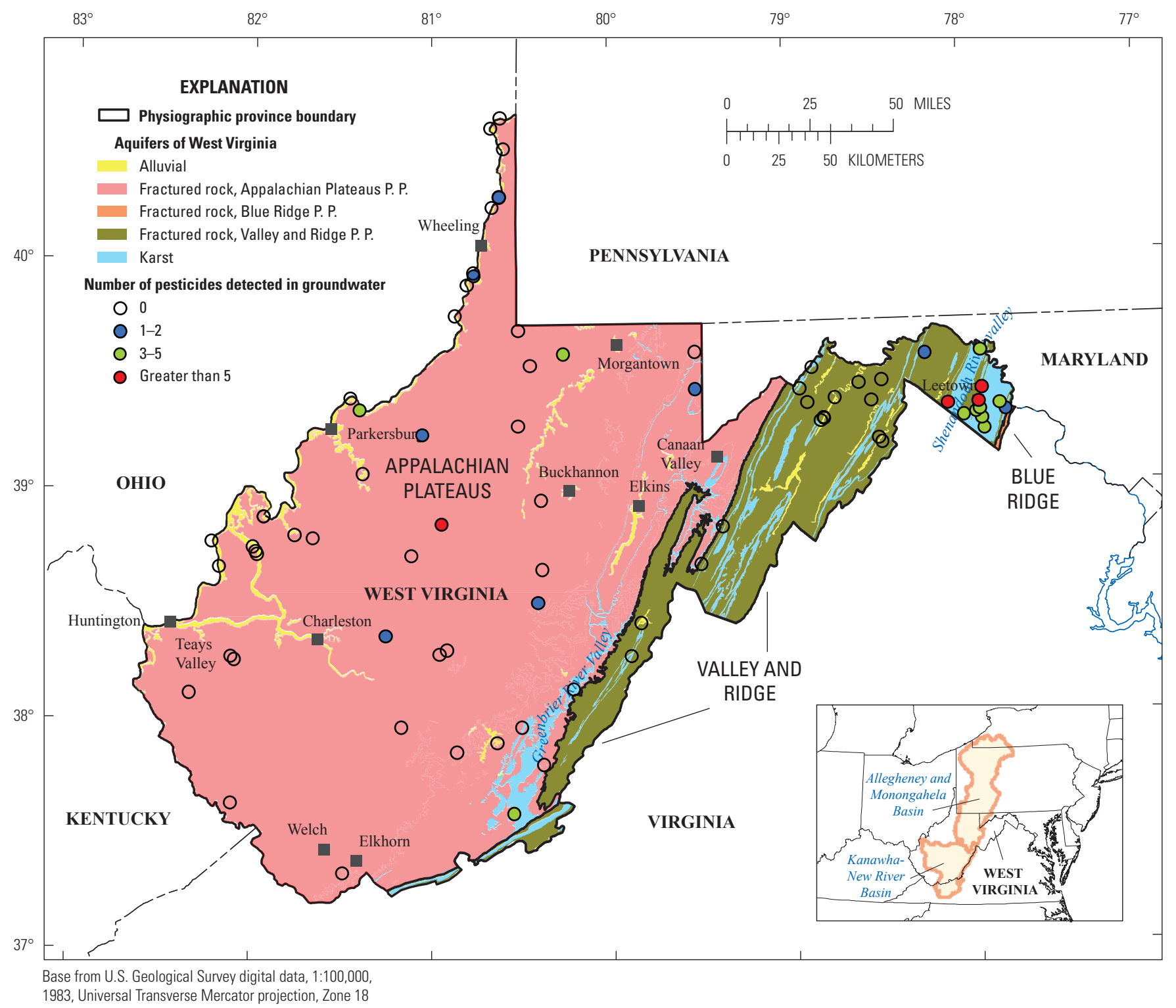

Figure 22. Distribution of pesticides in West Virginia's major aquifers, 1993-2008. (Data from Chambers and others, 2012; P. P., Physiographic Province)

one or more VOCs. The only other wells with detections of one or more VOCs are completed in the karst aquifer of the Shenandoah and Greenbrier River valleys with 8 of $20(40 \%)$ wells having detectable concentrations of one or more VOCs. Percentages of detections of VOCs in wells in fractured-rock aquifers within the Valley and Ridge and Appalachian Plateaus Physiographic Provinces were significantly less at only 12 and 21 percent, respectively. No wells sampled in the Valley and Ridge Physiographic Province fractured-rock aquifers had more than 3 VOC detections, and only 3 percent of the wells sampled in Appalachian Plateaus fractured-rock aquifers had more than 3 VOC detections. The higher proportion of VOC detections in karst and alluvial aquifers reiterates that these aquifers are intrinsically susceptible to contamination by agricultural and industrial activity and by potential spills that may occur on the land surface or in streams in these aquifer settings.

\section{Chlorofluorocarbons}

Chlorofluorocarbons (CFCs) are synthetic organic chemical compounds commonly used as refrigerants. Since the introduction of CFC gases as refrigerants in the late 1930s, atmospheric concentrations increased until production ceased in the mid-1990s. Concentrations of CFCs are commonly used to assess the relative age of groundwater and to assess mixing proportions of younger and older water. CFC 


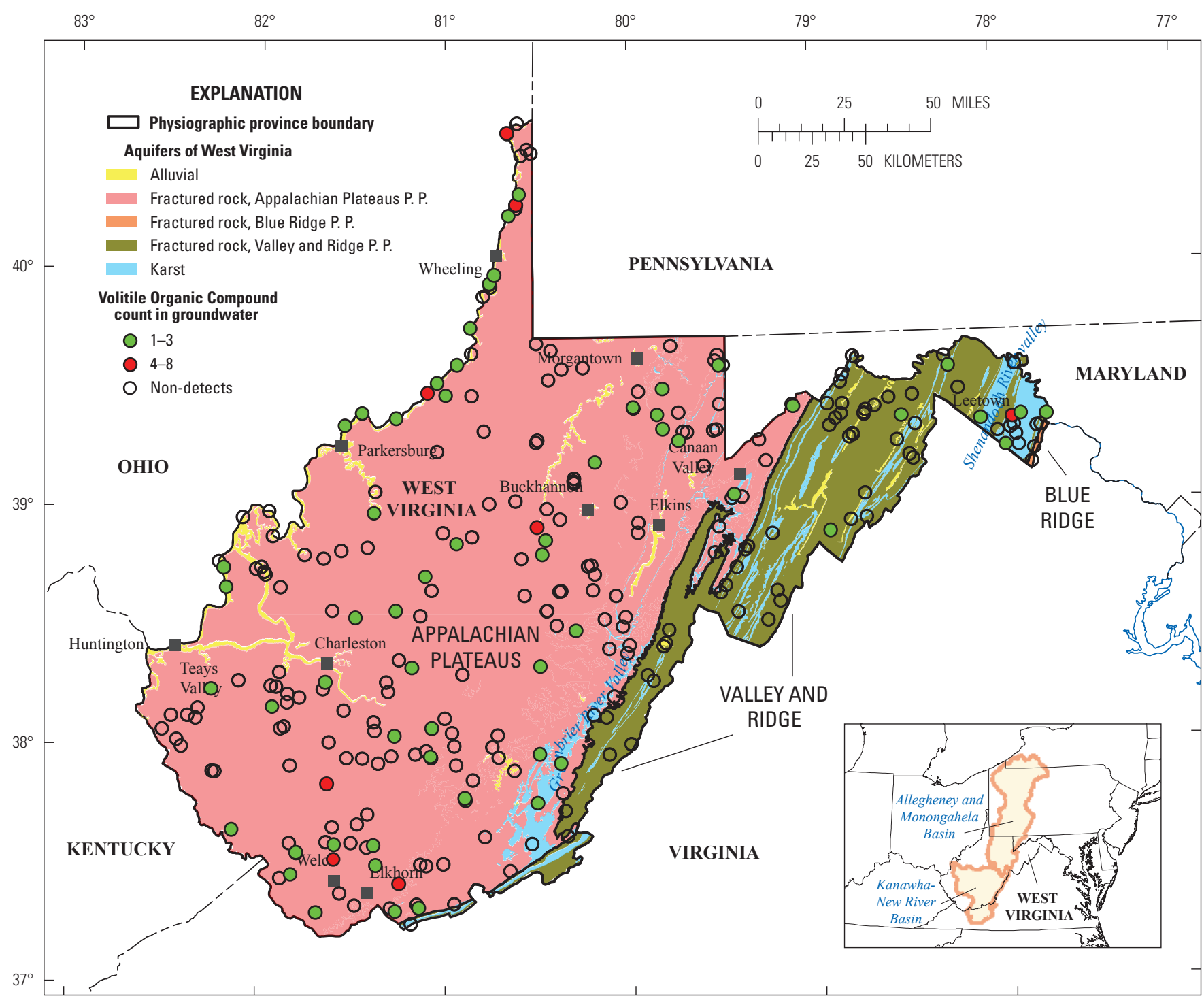

Base from U.S. Geological Survey digital data, 1:100,000,

1983, Universal Transverse Mercator projection, Zone 18

Figure 23. Distribution of volatile organic compounds in West Virginia's major aquifers, 1993-2008. (Data from Chambers and others, 2012; P. P., Physiographic Province).

age dating was conducted as a routine part of sampling for the USGS Kanawha/New River and Allegheny/Monongahela River NAWQA studies in the late 1990s and as part of the AMBGWMN through 2005. On the basis of these available data, a report was written to summarize CFC data with respect to groundwater age for West Virginia's major aquifers (McCoy and Kozar, 2007).

A study conducted by the USGS in Virginia used CFCs as a major factor in evaluating the intrinsic susceptibility of aquifers in Virginia (Nelms and others, 2003). Eberts and others (2013) evaluated the intrinsic susceptibility of several principal aquifers in the United States on the basis of a variety of age-dating methods. CFC data available for the 111 wells sampled in West Virginia indicate that groundwater in aquifers of West Virginia ranged in age from 5.9 to 56 years. The median age of all water samples was 19 years, and the median ages of water samples from the Appalachian Plateaus and Valley and Ridge Physiographic Provinces, and the Ohio River alluvial aquifers, were 21, 13, and 20 years, respectively. Wells in Appalachian Plateaus fractured-rock aquifers had median ages for hilltop, hillside, and valley wells of 12 , 14 , and 25 years, respectively. The percentages of young groundwater that mixed with older water were approximately 85,52 , and 57 percent for hilltop, hillside, and valley settings, respectively. This is important because it indicates that if anthropogenic contaminants were to reach wells in these settings via young water, the contamination would be diluted by mixing with approximately 15,48 , and 43 percent of older, 
potentially contaminant-free water (for wells on hilltops, hillsides, and valley settings, respectively). Thus, wells on hilltops in the Appalachian Plateaus Physiographic Province have the least dilution potential (and thus the greatest intrinsic susceptibility) relative to wells in other topographic settings, if contamination were to occur. For wells in the Valley and Ridge fractured-rock aquifers, the distributions were different, with median ages for hilltop, hillside, and valley wells of 18 , 21 , and 13 years, respectively, and percentage of young water for hilltop, hillside, and valley wells of 66, 62, and 61 percent, respectively. Unlike the Appalachian Plateaus Physiographic Province, groundwater age is not solely driven by topography, but circulation to depths in excess of 1,000 feet is possible along bedding planes (Hobba and others, 1979). The median age for valley wells in the Ohio River alluvial aquifer was 20 years, but 100 percent of the water for the five wells sampled was young water, indicating that wells in this setting have a very high intrinsic susceptibility with no dilution potential with older contaminant-free water.

The CFC age data indicate that all aquifers in West Virginia are susceptible to contamination by VOCs and other industrial chemical compounds, at least to some degree. However, the lack of occurrence of VOCs in fractured-rock aquifers within the State, and their preponderance in Ohio River alluvial aquifer and the karst aquifer of the Shenandoah River valley, indicates that potential sources of these contaminants may be more prevalent for these aquifers than for fracturedrock aquifers elsewhere in the State, or that the rapid flow in these aquifers allows contaminants to reach wells before the contaminants can degrade. As Ohio River alluvial aquifers contain nearly 100 percent of young water, CFC data indicate that they are especially susceptible to contamination by VOCs and other similar industrial chemical compounds. The young age of groundwater in hilltop settings in Appalachian Plateaus Physiographic Province fractured-rock aquifer (12 years) and in valley settings in the Valley and Ridge Physiographic Province fractured-rock aquifer (13 years) indicates that wells in these settings may also be more vulnerable to contamination than wells in other aquifers and topographic settings.

Unfortunately at the time of the CFC study (2007), data on CFCs in the Shenandoah River valley karst aquifer were sparse. Fortunately, a later groundwater age-dating study was completed for the Leetown area in Jefferson County within the karst aquifer of the Shenandoah River valley (Plummer and others, 2013). The age tracers tritium and helium $\left({ }^{3} \mathrm{H} /{ }^{3} \mathrm{He}\right)$, sulfur hexafluoride $\left(\mathrm{SF}_{6}\right)$, and $\mathrm{CFCs}$ were used to determine the age of groundwater in the area. For ${ }^{3} \mathrm{H} /{ }^{3} \mathrm{He}$ tracers, groundwater ages of spring water discharging from the carbonate rocks showed transient behavior, with ages averaging about 2 years in 2004 following a wet climatic period (2003-2004) and ranging from 4 to 7 years in periods of more average precipitation (2008-09). For SF6 and CFC tracers, data indicate older water (modeled ages of tens of years or more) in the lowpermeability shale of the Martinsburg Formation to the west of Leetown. The very young age of groundwater (2-7 years) documented for karst limestone aquifers in the Shenandoah
River valley, together with potential rapid transport in the epikarst or via solution conduits (Kozar and others, 2007a, b; Kozar and Weary, 2009) within the karst aquifer, indicates that the Shenandoah River valley karst aquifers are the most vulnerable aquifers within the State with respect to surficial land use and activities occurring at or near the land surface.

\section{Potential Sources of Contamination as a Factor for Assessing Vulnerability}

Vulnerability to contamination is dependent on (1) the intrinsic susceptibility of the various hydrogeologic terrains to contamination, (2) the sources of contamination within the recharge area to individual wells, and (3) the geochemical environment in the subsurface that affects contaminant mobility and persistence. Location data for 948 public groundwater systems were investigated, but only a subset of the systems (927) had a source-water-protection area delineation made by the WVDHHR (William J. Toomey, West Virginia Department of Health and Human Resources written commun., 2015). Using GIS, these 927 source-water-protection areas were intersected with land-use data obtained from the WVDEP (Brian A. Carr, West Virginia Department of Environmental Protection written commun., 2015). The number and type of potential sources of contamination within source-water-protection areas are summarized in table 3. A full list of individual groundwater systems and the number of potential sources of contamination within the source-water-protection area of the well is presented in appendix 3 .

The data available in appendix 3 can be used in conjunction with the intrinsically susceptible aquifers identified within this report to determine whether or not individual groundwater sources are potentially SWIGS. These determinations will be made by the WVDHHR using the data summarized within this report and additional site-specific data, if available.

The GIS assessment of potential sources of contamination to production wells and their respective source-waterprotection areas revealed interesting trends. Many of the potential sources of contamination identified in appendix 3 have been previously identified by the WVDHHR or by individual municipal water systems, public service water districts, or other groundwater suppliers. Therefore, there is some redundancy in the number of potential sources of contamination available from the WVDHHR and other data obtained elsewhere for analysis in this study (table 3 and appendix 3). Significant potential sources of contamination to public groundwater supplies in West Virginia are major rivers or streams, if there is a hydrologic connection between the rivers or streams and a production well or spring. Approximately 76 percent of public groundwater supplies had one or more streams within the associated source-water-protection area, and approximately 26 percent are within the 100 -year flood plain of a stream or river. Although a large number of public groundwater sources may be near major streams or in 
Table 3. Summary of data derived from geographic information system analyses of datasets on land use and potential sources of contamination pertaining to individual source-water-protection areas in West Virginia.

[SWPA, source water protection area; FEMA, Federal Emergency Management Agency; NPDES, National Pollutant Discharge Elimination System; WVDHHR, West Virginia Department of Health and Human Resources; 100K, 100,000 scale; RCRA, Resource Conservation and Recovery Act]

\begin{tabular}{|c|c|c|}
\hline Land use within the source water protection area & Number of sites in SWPAs & $\begin{array}{l}\text { Percent of SWPAs with respective } \\
\text { land use }\end{array}$ \\
\hline Abandoned mine land (AML) points & 69 & 7.4 \\
\hline Abandoned mine lands (AML) polygons & 82 & 8.8 \\
\hline Above ground storage tanks (AST unique) & 330 & 35.6 \\
\hline Below ground storage tanks & 199 & 21.5 \\
\hline FEMA floodways & 245 & 26.4 \\
\hline Landfill closure sites & 3 & 0.3 \\
\hline NPDES permitted outfalls & 435 & 46.9 \\
\hline Railroads & 303 & 32.7 \\
\hline Special reclamation sites & 24 & 2.6 \\
\hline Streams from $100 \mathrm{~K}$ topographic maps & 706 & 76.2 \\
\hline Superfund, RCRA or other hazardous waste sites & 493 & 53.2 \\
\hline Potential sources of contamination (WVDHHR) * & 850 & 91.7 \\
\hline
\end{tabular}

* The WVDHHR potential sources of contamination may include data that is duplicated in other categories summarized in this table.

100-year flood plains, they may not be vulnerable to contamination if aquifers are not intrinsically susceptible, if the wells were constructed properly to protect against potential entry of surface water during periods of flooding, and if there is no hydraulic connection between the surface-water body and production wells or springs.

Contaminated sites such as Resource Conservation and Recovery Act (RCRA), Superfund, or voluntarily reclaimed sites, such as old gas stations, are present in more than onehalf of the source-water-protection areas evaluated. Outfalls (discharge points for waste streams to a water body) from permitted National Pollutant Discharge Elimination System (NPDES) sources, such as sewage treatment return flows, coal mine impoundment return flows, or other industrial process return flows, are present in high proportion, with more than 46 percent of source-water-protection areas containing one or more NPDES outfalls. Major transportation corridors, such as major roads (interstates or U.S. highways) and railroads, are present in 30 and 32 percent of source-water-protection areas, respectively. Other potential sources of contamination, such as gas wells, above-ground storage tanks, and underground storage tanks are present in approximately 24,35 and 21 percent, of source-water-protection areas assessed during this study, respectively. Fifteen of 927 sites (1.6\%) had no contamination sources within the protection area, and the median number of potential contamination sources for individual production wells was four. The maximum number of contamination sources within a source-water-protection area was 14, and 104 sites had 10 or more potential contamination sources within their respective source-water-protection area. It is clear that the presence of a potential source of contamination within a source-waterprotection area does not necessarily result in well contamination. But the presence of numerous potential contamination sources, in conjunction with an aquifer with high intrinsic susceptibility, indicates that a site-specific investigation of vulnerability may be warranted for determination of SWIGS. 


\section{Summary of Aquifer Susceptibility and Vulnerability}

Results of previous investigations consistently show similar trends and improve the understanding of the factors that are inherent to the intrinsic susceptibility and vulnerability of groundwater in West Virginia to contamination. Because the types and availability of data vary widely for the various hydrogeologic terrains, a quantitative assessment of aquifer susceptibility and vulnerability is not possible. In order to prioritize those hydrogeologic terrains that are especially intrinsically susceptible or vulnerable to contamination, a diagram was be prepared with simple scales to illustrate overall trends in aquifer susceptibility and vulnerability (fig. 24). It is emphasized that the chart, although based on observed data and trends from past hydrogeologic studies, is only qualitative and individual SWIGS determinations need to be made on a case-by-case basis. On the basis of previous investigations and limited available data, karst aquifers are the most intrinsically susceptible and vulnerable aquifers within the State of West Virginia, followed by alluvial aquifers (especially along the Ohio River), fractured metamorphic and igneous aquifers, below-drainage coal-mine aquifers, and above-drainage coalmine aquifers. Overall, fractured sedimentary-rock aquifers have low intrinsic susceptibility and aquifer vulnerability.

Intrinsic susceptibility alone does not equate to overall vulnerability to contamination, but is a primary factor to consider when assessing potential susceptibility of a well or spring to contamination. Determining whether or not a particular well or spring is a SWIGS is a task that will be completed by the WVDHHR on a site-by-site basis, using site-specific criteria. The data and results of previous investigations summarized in this report identify known areas of existing widespread contamination and provide a mechanism by which the WVDHHR may prioritize the assessment of SWIGS statewide. Measures can be taken to educate the local population and initiate protocols and protective strategies to

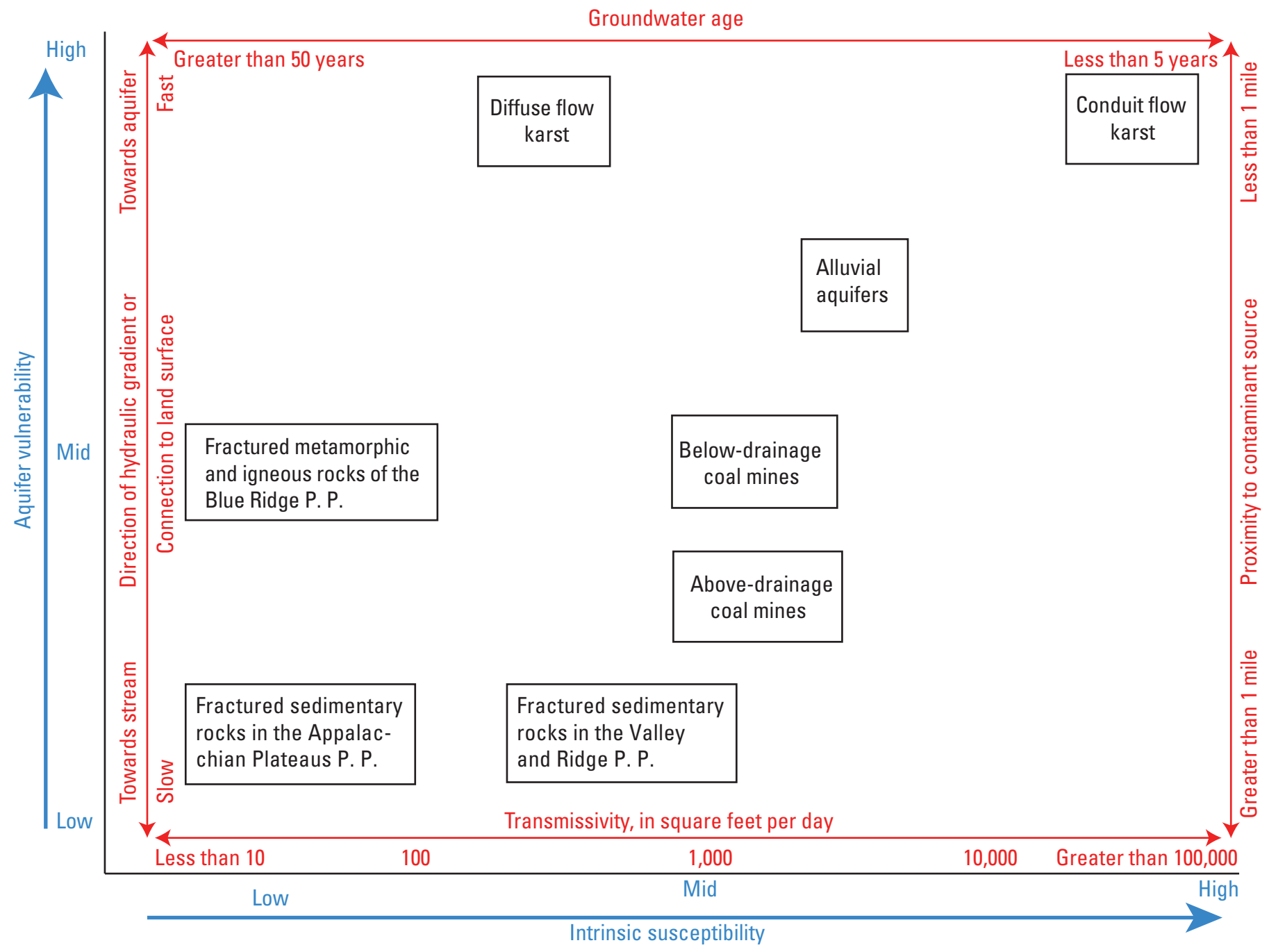

Figure 24. Conceptual qualitative assessment of intrinsic susceptibility and aquifer vulnerability for various hydrogeologic terrains in West Virginia. (P. P., Physiographic Province) 
appropriately manage contaminant sources to prevent release of contaminants to the aquifer, therefore reducing vulnerability of these systems to contamination.

\section{Summary}

In January 2014, a storage tank leaked, spilling a large quantity of 4-methylcyclohexane methanol into the Elk River in West Virginia contaminating the water supply for more than 300,000 people. In response, the West Virginia Legislature passed Senate Bill 373, which requires the West Virginia Department of Health and Human Resources (WVDHHR) to assess the susceptibility and vulnerability of public surfacewater-influenced groundwater supply sources (SWIGS) and surface-water intakes statewide. In response to this mandate for reassessing SWIGS statewide, the U.S. Geological Survey (USGS), in cooperation with the WVDHHR, Bureau of Public Health, Office of Environmental Health Services, compiled available data and summarized the results of previous groundwater studies to provide the WVDHHR with data that could be used as part of the process for assessing and determining SWIGS.

The USGS has been conducting hydrogeologic and water-quality studies within the State of West Virginia since about 1940. More than 40 publications were reviewed and summarized to provide additional information that could be used to aid in SWIGS determinations, particularly regarding intrinsic susceptibility of aquifers. Hydrogeologic terrains were identified on the basis of aquifer properties, transmissivity estimates, and physiographic province, and were assessed with respect to intrinsic susceptibility to contamination. Available water-quality and aquifer transmissivity data from USGS databases were collected, compiled, and assessed to link aquifer susceptibility, which is based on non-anthropogenic factors, with known contamination resulting from anthropogenic factors.

Available data in USGS water-quality and groundwater databases were retrieved and brought into a geographic information system (Arc-GIS) for spatial analysis. Some of the data used for spatial analysis include locations of production wells (provided by the WVDHHR), distance to transportation corridors, type and number of potential sources of contaminants in the designated source-water-protection area of the well, locations of 100-year flood plains, locations of nearby streams or rivers, and locations of permitted coal mines. The Arc-GIS generated datasets can be used in the statewide assessment for determination of SWIGS.

Water-quality and microbial data were available from a statewide assessment of groundwater quality that was completed in 2012. These data were used to make direct observations of aquifer and well vulnerability and to determine spatial patterns of vulnerability in different hydrogeologic settings. Additional data on well-construction characteristics, such as well depth and length of well casing, were retrieved from the
USGS Groundwater Site Inventory database and paired with water-quality data from the USGS water-quality database to assess the importance, or lack thereof, of well depth and length of casing in microbial contamination of wells. Wells with casings deeper than 45 feet below land surface had less bacterial contamination than did wells with shorter well casings.

Data on chlorofluorocarbons in groundwater indicate the relative age of groundwater in selected aquifers (hydrogeologic terrains) within the State, the potential mixtures of older groundwater ( $>50$ years) and younger groundwater ( $<50$ years), and the dilution potential of water recharging a well should it become contaminated. Median ages of water in Appalachian Plateaus Physiographic Province, Valley and Ridge Physiographic Province, Ohio River alluvial aquifer, and Cambrian-Ordovician-age karst aquifers were 21, 13, 20, and 5 years, respectively. The median ages represent a mixture of older and younger groundwater. Almost 100 percent of water derived from Ohio River alluvial aquifer and a high percentage of water in Cambrian-Ordovician karst aquifers contain young water, which makes them more susceptible to contamination than aquifers in other hydrogeologic terrains in the State.

A review of existing protocols used by the WVDHHR to determine groundwater under direct influence (GWUDI) of surface water was also conducted. Because the GWUDI and SWIGS processes are similar, the protocols used for determining GWUDI sites can be applied, at least partially, to the determination of SWIGS. All the aforementioned data have been assessed to provide additional data that may help in the process of assessing potential SWIGS.

On the basis of results of analysis of the available hydrogeologic, chemical, and microbial data, karst aquifers in West Virginia's eastern panhandle and in the Greenbrier River valley were found to be the aquifers most susceptible to contamination within the State. Karst aquifers are highly susceptible to contamination owing to the rapid ease with which precipitation and surface water can infiltrate and recharge groundwater aquifers, carrying along with the recharge water any contaminants that may be present at the land surface. Karst aquifers within West Virginia are especially susceptible to contamination from agricultural sources. Nitrate, pesticides, and fecal, total coliform, and Escherichia coli (E. coli) bacteria are the contaminants most commonly found in the karst aquifers within the State.

Alluvial aquifers along the Ohio River are also highly susceptible to contamination because the composition of alluvial sediments can be very permeable and allow rapid infiltration of precipitation or induced recharge from the nearby river. Because microbial contamination of Ohio River water is common and agriculture along the banks of the Ohio River is a major land use, nitrate and pesticide contamination resulting from agricultural processes occurring at the land surface is possible. Steel mills, power plants, chemical plants, and other industrial plants are common on the alluvial terraces bordering the Ohio River; therefore, potential exists for contamination of the aquifer by volatile organic and semi-volatile 
organic compounds. Fortunately, the sand and gravel alluvial sediments that compose the Ohio River alluvial aquifer are effective traps for removing bacteria and other pathogenic organisms, such as Giardia lamblia, Cryptosporidia, and viruses; therefore, Ohio River alluvial aquifers are not highly susceptible to microbial contamination.

Fractured-rock aquifers in West Virginia are present in two distinct physiographic provinces - the Appalachian Plateaus and the Valley and Ridge Physiographic Provinces. Three types of fractured-rock aquifers are present in West Virginia - (1) the Appalachian Plateaus fractured-rock aquifers, which are composed of relatively flat-lying interbedded layers of sandstone, shale, siltstone, mudstone, coal, and thin limestone beds; (2) the thin limestone, sandstone, and shale aquifers in the highly folded and faulted Valley and Ridge Physiographic Province, and (3) the fracturedrock aquifers composed of igneous and metamorphic rocks in the Blue Ridge Physiographic Province. Fractured-rock aquifers, because of their very small groundwater capture areas, typically have a low intrinsic susceptibility to surface contaminants. Although fractured-rock aquifers are not highly susceptible to contamination, they may be vulnerable to contamination by bacteria, nitrates, pesticides, and other contaminants, if such contaminants are applied or spilled on the land surface in the immediate vicinity of a well. The Blue Ridge fractured-rock aquifers are susceptible to greater than background levels of naturally occurring radon, a radioactive carcinogenic gas known to cause lung cancer, which is derived from the decay of uranium.

Abandoned coal-mine aquifers are of two categories. The first category is the above-drainage underground coal-mine aquifer. These are abandoned coal mines that are present at an elevation above surrounding tributary streams. As such, they are not heavily influenced by streams or rivers and receive most of their recharge from overlying bedrock strata. As overlying bedrock strata are typically devoid of human presence, the potential for infiltration of precipitation or recharge with elevated concentrations of bacteria, nutrients, pesticides, or organic chemical compounds is typically low. Therefore, above-drainage underground coal mines probably have a low susceptibility to contamination.

Below-drainage underground coal mines are a second category of coal-mine aquifer and are present below the elevation of local tributaries and streams. Because the mining process can substantially fracture overburden strata, the coalmine aquifers are moderately susceptible to contamination by surface water percolating downward from overlying strata. If the overlying streams have a significant load of bacteria, the underlying coal-mine aquifer can easily be contaminated by bacteria discharged to the overlying stream from septic return flows, surface runoff, sewage treatment plant return flows, or direct discharge of untreated sewage to streams, which unfortunately occurs in certain areas of West Virginia.

Groundwater public-supply systems in areas of high intrinsic susceptibility and with a large number of potential contaminant sources within the recharge or source-water-protection area of individual wells or well fields are potentially vulnerable to contamination and probably warrant further evaluation as potential SWIGS. However, measures can be taken to educate the local population and initiate safety protocols and protective strategies to appropriately manage contaminant sources to prevent release of contaminants to the aquifer, therefore reducing vulnerability of these systems to contamination. Each public groundwater supply source, however, needs to be assessed on an individual basis. Data presented in this report can be used to categorize and prioritize wells and springs that have a high potential for intrinsic susceptibility or vulnerability to contamination.

\section{References Cited}

American Public Health Association, American Water Works Association, and Water Environment Foundation, 2005, Enzyme Substrate Coliform Test, Standard methods for the examination of water and wastewater (21st ed.): Washington D.C. [variously paged].

Bain, G.L., 1970, Salty ground water in West Virginia with a discussion of the Pocatalico River basin above Sissonville: West Virginia Geological and Economic Survey Circular 11, $31 \mathrm{p}$.

Bieber, P.P., 1961, Ground-water features of Berkeley and Jefferson Counties, West Virginia: West Virginia Geological and Economic Survey Bulletin 21, 81 p.

Boughton, C.J., and McCoy, K.J., 2006, Hydrogeology, aquifer geochemistry, and ground-water quality in Morgan County, West Virginia: U.S. Geological Survey Scientific Investigations Report 2006-5198, 56 p.

Callaghan, Thomas, Fleeger, G.M., Barnes, Scott, and Dalberto, Al, 1998, Chapter 2, Groundwater flow on the Appalachian Plateaus of Pennsylvania, in Brady, K.B.C., Smith, M.W., and Schueck, Joseph, eds., Coal mine drainage prediction and pollution prevention in Pennsylvania: Harrisburg, Pa., Pennsylvania Department of Environmental Protection, $39 \mathrm{p}$.

Cardwell, D.H., Erwin, R.B., and Woodward, H.P., 1968, Geologic map of West Virginia: West Virginia Geological and Economic Survey map, 2 sheets, scale 1:250,000.

Carlston, C.W., 1958, Ground-water resources of Monongalia County, West Virginia: West Virginia Geological and Economic Survey Bulletin No. 15, 12 p., 21 appendices, and 2 pls.

Chambers, D.B., Kozar, M.D., White, J.S., and Paybins, K.S., 2012, Groundwater quality in West Virginia, 1993-2008: U.S. Geological Survey Scientific Investigations Report 2012-5186, $47 \mathrm{p}$. 
Dasher, G.R., 2012, The caves and karst of West Virginia: West Virginia Speleological Society Bulletin no. 19, 264 p.

Dicken, C.L., Nicholson, S.W., Horton, J.D., Kinney, S.A., Gunther, G., Foose, M.P., and Mueller, J.A.L., 2005, Integrated Geologic Map Databases for the United States: Delaware, Maryland, New York, Pennsylvania, and Virginia: U.S.Geological Survey Open-File Report 2005-1325, report and GIS spatial and metadata accessed April 20, 2016, at http://pubs.usgs.gov/of/2005/1325/.

Doll, W.L., Wilmoth, B.M., and Whetstone, G.W., 1960, Water resources of Kanawha County, West Virginia: West Virginia Geological and Economic Survey Bulletin 20, 189 p.

Eberts, S.M., Thomas, M.A., and Jagucki, M.L., 2013, The quality of our Nation's waters - Factors affecting public supply-well vulnerability to contamination - Understanding observed water quality and anticipating future water quality: U.S. Geological Survey Circular 1385, 120 p., http://pubs. usgs.gov/circ/1385/.

Evaldi, R.D., and Paybins, K.S., 2006a, Channel gains and losses in the Opequon Creek Watershed of West Virginia, July 25-28, 2005: U.S. Geological Survey Data Series 179, 7 p., 1 pl.

Evaldi, R.D., and Paybins, K.S., 2006b, Base-flow yields of watersheds in the Berkeley County Area, West Virginia: U.S. Geological Survey Data Series 216, 4 p., 1 pl.

Fenneman, N.M., and Johnson, D.W., 1946, Physical Division of the United States scale 1:7,000,000, accessed digitally from Kerie Hitt, U.S. Geological Survey in 1999 at http:// water.usgs.gov/GIS/metadata/usgswrd/XML/physio.xml.

Ferrell, G.M., 1992, Hydrologic characteristics of abandoned coal mines used as a source of public water supply in McDowell County, West Virginia: U.S. Geological Survey Water-Resources Investigations Report 92-4073, 37 p.

Focazio, M.J., Reilly, T.E., Rupert, M.G., and Helsel, D.R., 2002, Assessing ground-water vulnerability to contamination - providing scientifically defensible information for decision makers: U.S. Geological Survey Circular 1224, $33 \mathrm{p}$.

Foster, J.B., 1980, Fresh and saline ground water map of West Virginia: West Virginia Geological and Economic Survey Map WV-12, 2 sheets.

Freeze, R.A., and Cherry, J.A., 1987, Groundwater: Englewood Cliffs, N.J., Prentice-Hall, Inc., 604 p.

Gidley, H.K., 1952, Installation and performance of radial collector wells in Ohio River gravels: Journal of the American Water Works Association, v. 44, no. 12, p. 1117-1126.
Goode, D.J., Senior, LA., and Risser, D.W., 2014, Streamflow depletion by groundwater pumping from fractured-rock aquifers of the Newark Basin [abs.]: 2014 Pennsylvania Ground Symposium, May 7, 2014, State College, Pennsylvania. [Also available at http://pa.water.usgs.gov/projects/ frhr/goode2014b.php]

Harbaugh, A.W., Banta, E.R., Hill, M.C., and McDonald, M.G., 2000, MODFLOW-2000, The U.S. Geological Survey modular groundwater flow model - User guide to modularization concepts and ground-water flow processes: U.S. Geological Survey Open-File Report 00-92, 121 p.

Harlow, G.E., and LeCain G.D., 1993, Hydraulic characteristics of, and ground-water flow in, coal-bearing rocks of southwestern Virginia: U.S. Geological Survey Water-Supply Paper 2388, 36 p.

Hobba, W.A., Jr., 1976, Ground-water hydrology of Berkeley County, West Virginia: West Virginia Geological and Economic Survey Economic Geology Bulletin 13, 21 p.

Hobba, W.A., Jr., 1981a, Ground-water hydrology of Jefferson County, West Virginia: West Virginia Geological and Economic Survey Economic Geology Bulletin 16, 21 p.

Hobba, W.A., Jr., 1981b, Effects of underground mining and mine collapse on the hydrology of selected basins in West Virginia: West Virginia Geological Survey Report of Investigation RI-33, $77 \mathrm{p}$.

Hobba, W.A., 1987, Underground coal mines as sources of water for public supply in northern Upshur County, West Virginia: U.S. Geological Survey Water-Resources Investigations Report 84-4115, 38 p.

Hobba, W.A., Jr., Fisher, D.W., Pearson, F.J., Jr., and Chemerys, J.C., 1979, Hydrology and geochemistry of thermal springs of the Appalachians: U.S. Geological Survey Professional Paper 1044-E, $36 \mathrm{p}$.

Jeffords, R.M., 1945, Recharge to water-bearing formations along the Ohio Valley: Journal of the American Water Works Association, v. 37, no. 2, 10 p.

Jones, W.K., 1973, Hydrology of limestone karst: West Virginia Geological Survey Bulletin 36, 49 p. 2 pls.

Jones, W.K., 1997, Karst Hydrology Atlas of West Virginia: Karst Waters Institute Special Publication 4, 111 p.

Kazmann, R.G., Jeffords, R.M., and Schaefer, E.J., 1943, Water supply of the West Virginia Ordnance Works, Pt. Pleasant, West Virginia: U.S. Geological Survey Open-File Report, 150 p.

Kozar, M.D., 1996, Geohydrology and ground-water quality of Southern Canaan Valley, Tucker County, West Virginia: U.S. Geological Survey Water-Resources Investigation Report 96-4103, 102 p. 
Kozar, M.D., Hobba, W.A., and Macy, J.A., 1991, Geohydrology, water availability, and water quality of Jefferson County, West Virginia, with emphasis on the carbonate area: U.S. Geological Survey Water-Resources Investigation Report 90-4118, 93 p.

Kozar, M.D., and Mathes, M.V., 2001, Aquifer characteristics data for West Virginia: U.S. Geological Survey WaterResources Investigations Report 01-4036, 74 p.

Kozar, M.D., and McCoy, K.J., 2004, Geohydrology and simulation of ground-water flow in Ohio River alluvial aquifers near Point Pleasant, Lubeck, Parkersburg, Vienna, Moundsville, and Glendale, West Virginia: U.S. Geological Survey Scientific Investigations Report 2004-5088, 39 p.

Kozar, M.D., McCoy, K.J., Britton, J.Q., and Blake, B.M. Jr., 2012, Hydrogeology, groundwater flow, and groundwater quality of an abandoned underground coal mine aquifer, Elkhorn area, West Virginia: West Virginia Geological and Economic Survey Bulletin B-46, 103 p.

Kozar, M.D., Weary, D.J., Paybins, K.S., and Pierce, H.A., 2007a, Hydrogeologic setting and ground-water flow in the Leetown Area, West Virginia: U.S. Geological Survey Scientific Investigations Report 2007-5066, 70 p.

Kozar, M.D., McCoy, K.J., Weary, D.J., Field, M.S., Pierce, H.A., Schill, W.B., and Young, J.A., 2007b, Hydrogeology and water quality of the Leetown area, West Virginia: U.S. Geological Survey Open-File Report 2007-1358, 100 p., 6 appendixes.

Kozar, M.D., Sheets, C.J., and Hughes, C.A., 2001, Groundwater quality and geohydrology of the Blue Ridge Physiographic Province, New River Basin, Virginia and North Carolina: U.S. Geological Survey Water-Resources Investigations Report 00-4270, 36 p.

Kozar, M.D., and Weary, David J., 2009, Hydrogeology and ground-water flow in the Opequon Creek watershed area, Virginia and West Virginia: U.S. Geological Survey Scientific Investigations Report 2009-5153, 61 p.

Lessing, P., and Hobba, W.A. Jr., 1981, Abandoned coal mines in West Virginia as sources of water supplies: West Virginia Geological and Economic Survey Circular C-24, 18 p.

Lohman, S.W., 1972, Ground-water hydraulics: U.S. Geological Survey Professional Paper 708, 70 p., 9 pls.

Mathes, M.V., 2000, Relation of bacteria in limestone aquifers to septic systems in Berkeley County, West Virginia: U.S. Geological Survey Water-Resources Investigations Report 00-4229, 12 p.
Mathes, M.V., Jr., Kozar, M.D., and Brown, D.P., 1998, Summary of ground-water quality in West Virginia: West Virginia Division of Environmental Protection, Office of Water Resources, Ground-Water Program, 54 p.

McAuley, S.D., and Kozar, M.D., 2006, Ground-water quality in unmined areas and near reclaimed surface mines in the Northern and Central Appalachian Coal Regions, Pennsylvania and West Virginia: U.S. Geological Survey Scientific Investigations Report 2006-5059, 57 p.

McColloch, J.S., Binns, R.D., Blake, B.M. Jr., Clifford, M.T., and Gooding, S.E., 2012, West Virginia Mine Pool Atlas: Final project report prepared by the West Virginia Geological and Economic Survey and submitted to the West Virginia Department of Environmental Protection as part of interagency agreement number 036, 133 p., 4 appendices.

McCoy, K.J., and Kozar, M.D., 2007, Relation of chlorofluorocarbon age dates to water quality in aquifers of West Virginia: U.S. Geological Survey Scientific Investigations Report 2006-5221, 36 p.

McDonald, M.G., and Harbaugh, A.W., 1988, A modular three-dimensional finite difference groundwater flow model: U.S. Geological Survey Techniques of Water-Resources Investigations of the United States Geological Survey, Chapter A1, $587 \mathrm{p}$.

Nace, R.L., and Bieber, P.B., 1958, Groundwater resources of Harrison County, West Virginia: West Virginia Geological and Economic Survey Bulletin No. 14, 55 p.

Nelms, D.L., Harlow, G.E. Jr., Plummer, L.N., and Busenburg E., 2003, Aquifer susceptibility in Virginia, 1998-2000: U.S. Geological Survey Water-Resources Investigations Report 03-4278, $58 \mathrm{p}$.

Nelms, D.L., Messinger, Terence, and McCoy, K.J., 2015, Annual and average estimates of water-budget components based on hydrograph separation and PRISM precipitation for gaged basins in the Appalachian Plateaus Region, 1900-2011: U.S. Geological Survey Data Series 944, 10 p.

Nicholson, S.W., Dicken, C.L., Foose, M.P., and Mueller, J.A.L. 2005, Integrated Geologic Map Databases for the United States: Alabama, Florida, Georgia, Mississippi, North Carolina, and South Carolina; U.S. Geological Survey Open-File Report 2005-1323, report and GIS spatial and metadata accessed April 20, 2016, at http://pubs.usgs. gov/of/2005/1323/.

Otton, J.K. 1992, The geology of radon: U.S. Geological Survey Special Publications pamphlet: U.S. Government Printing Office 1192 0-326-248, 30 p. 
Plummer, N.L., Sibrell, P.L., Casile, G.C., Busenburg, E., Hunt, A.G., and Schlosser, P., 2013, Tracing groundwater with low-level detections of halogenated VOCs in a fractured carbonate-rock aquifer, Leetown Science Center, West Virginia: Applied Geochemistry, v. 33, p. 260-280.

Puente, C., 1985, West Virginia groundwater resources, in 1984 National Water Summary: U.S. Geological Survey Water-Supply Paper 2275, p. 439-446.

Robison, T.M., 1964, Occurrence and availability of ground water in Ohio County, West Virginia: West Virginia Geological and Economic Survey Bulletin 27, 57 p.

Rutledge, A.T., 1998, Computer programs for describing the recession of groundwater recharge and discharge from streamflow records - Update: U.S. Geological Survey Water-Resources Investigations Report 98-4148, 43 p.

Schwietering, J.F., 1981, Brief description of ground water conditions and aquifers in West Virginia with annotated bibliography: West Virginia Geological and Economic Survey Open File Report OF-8102, 121 p.

Sheets, C.J., and Kozar, M.D., 2000, Ground-water quality in the Appalachian Plateaus, Kanawha River Basin, West Virginia: U.S. Geological Survey Water-Resources Investigations Report 99-4269, 25 p.

Shultz, R.A., 1988, Ground-water hydrology of Marshall County, West Virginia, with emphasis on the effects of longwall coal mining: U.S. Geological Survey Water-Resources Investigations Report 88-4006: 139 p., 7 pls.

Shultz, R.A., Hobba, W.A., and Kozar, M.D., 1995, Geohydrology and ground-water quality of Berkeley County, West Virginia, with emphasis on the carbonate area: U.S. Geological Survey Water-Resources Investigations Report 93-4073, 88 p.

Simard, C.M., 1989, Geologic history of the lower terraces and floodplains of the upper Ohio River valley: Morgantown, W.Va., West Virginia University Master's Thesis, $160 \mathrm{p}$.

Sloto, R.A., and Crouse, M.Y., 1996, HYSEP, a computer program for streamflow hydrograph separation and analysis: U.S. Geological Survey Water-Resources Investigations Report 96-4040, 46 p.

Sworobuk, J.T., 1984, Bacterial contamination of rural drinking water supplies, Preston County, West Virginia: Morgantown, W.Va., West Virginia University Master's Thesis, $92 \mathrm{p}$.
U.S. Environmental Protection Agency (EPA), 1999, Guidance manual for conducting sanitary surveys of public water systems, surface water and ground water under direct influence (GWUDI): U.S. Environmental Protection Agency publication EPA-815-R-99-016, 181 p.

U.S. Environmental Protection Agency (EPA), 2004, Ground Water Rule - Comprehensive Surface Water Treatment Rules Quick Reference Guide - Unfiltered Systems: U.S. Environmental Protection Agency publication EPA816-F-04-001, 4 p.

U.S. Environmental Protection Agency (EPA), 2008a, Ground Water Rule Source Water Assessment Guidance Manual: U.S. Environmental Protection Agency publication EPA-816-R-07-023, 100 p.

U.S. Environmental Protection Agency (EPA), 2008b, Ground Water Rule Corrective Actions Guidance Manual: U.S. Environmental Protection Agency publication EPA-815-R-08-011, 107 p.

U.S. Environmental Protection Agency (EPA), 2010a, Ground Water Rule: A Quick Reference Guide: U.S. Environmental Protection Agency publication EPA-816-F-08-029, 2 p.

U.S. Environmental Protection Agency (EPA), 2010b, Ground Water Rule - Comprehensive Surface Water Treatment Rules Quick Reference Guide - Systems Using Conventional or Direct Filtration: U.S. Environmental Protection Agency publication EPA-816-F-10-074, 4 p.

U.S. Environmental Protection Agency (EPA), 2011, Surface water treatment rules - What do they mean to you?: U.S. Environmental Protection Agency publication EPA-816-R-11-009, 94 p.

U.S. Environmental Protection Agency (EPA), 2015, Nitrates and nitrites: U.S. Environmental Protection Agency TEACH chemical summary, 14 p. [Also available at https://archive. epa.gov/region5/teach/web/pdf/nitrates_summary.pdf]

U.S. Geological Survey, Geographic Names Information System (GNIS), 2013. Digital data accessed 6/2015 from http:// wvgis.wvu.edu/data/dataset.php?ID=99.

U.S. Geological Survey National Atlas, 1999, Selected 1:2,000,000 scale streams of West Virginia, Digital data layer accessed from the National Atlas of the United States 1/31/2014 at http://nationalmap.gov/small_scale/atlasftp. html.

U.S. Geological Survey, 2002, West Virginia County Boundaries, scale 1:24,000, accessed 2009 at http:/wvgis.wvu.edu/ data/dataset.php?ID=136. 
West Virginia Department of Health and Human Resources, 2008, Water well regulations: West Virginia Legislative Rule 64CSR19 - Title 64, Series 19, 15 p.

West Virginia Department of Health and Human Resources, 1984, Water well design standards, chap. 16-1, series 3: West Virginia Bureau for Public Health report SW-255, 9 p.

West Virginia Bureau for Public Health, 1999, Guidance memorandum \# 23 - Ground water under direct influence (GWUDI) of surface water project, community and noncommunity transient water supply systems: West Virginia Bureau for Public Health memorandum, 13 p.

West Virginia Department of Environmental Protection, 2008, West Virginia Integrated Water Quality Monitoring and Assessment Report, 182 p.

West Virginia Department of Environmental Protection, 2014, Coal mine permit boundaries, accessed Septembed 24, 2014, at http://tagis.dep.wv.gov/home/?q=Downloads.

Wilmoth, B.M., 1966, Ground water in Mason and Putnam Counties, West Virginia: West Virginia Geological and Economic Survey Bulletin 32, 152 p.

Winston, R.B., 1999, Upgrade to MODFLOW-GUI; addition of MODPATH, ZONEBDGT, and additional MODFLOW packages to the U.S. Geological Survey MODFLOW-96 graphical user interface: U.S. Geological Survey Open-File Report 99-184, 72 p.

Winter, T.C., Judson, W.H., Franke, O.L., and Alley, W.A., 1998, Ground water and surface water, A single resource: U.S. Geological Survey Circular 1139, 79 p.

Wyrick, G.G., and Borchers, J.W., 1981, Hydrologic effects of stress relief fracturing in an Appalachian valley: U.S. Geological Survey Water-Supply Paper 2177, 51 p.

Yager, R.M., Southworth, S., and Voss, C.I., 2008, Simulation of groundwater flow in the Shenandoah Valley, Virginia and West Virginia, using variable-direction anisotropy in hydraulic conductivity to represent bedrock structure: U.S. Geological Survey Scientific Investigations Report 2008-5002, 55 p. 


\section{Appendixes 1, 2, and 3, available online as Excel files at http://dx.doi.org/10.3133/sir20165048}

\section{Appendix 1}

Description of 324 wells in West Virginia sampled as part of the U.S. Geological Survey and West Virginia Department of Environmental Protection statewide Ambient Groundwater Quality Monitoring Network.

\section{Appendix 2}

Description of wells in West Virginia, including casing length and well depth, that are part of the U.S. Geological Survey Groundwater Site Inventory database with Escherichia coli, fecal coliform, and total coliform data that are stored in the U.S. Geological Survey Water-Quality database.

\section{Appendix 3}

Permit data for public groundwater supplies in West Virginia with accompanying counts of number of potential sources of contamination within the respective source-water-protection area for each public groundwater supply source. 
Publishing support provided by the U.S. Geological Survey Science Publishing Network, West Trenton Publishing Service Center

For more information concerning the research in this report, contact: Director, West Virginia Water Science Center

U.S. Geological Survey

11 Dunbar Street, Charleston, WV 25301

http://wv.usgs.gov 
